
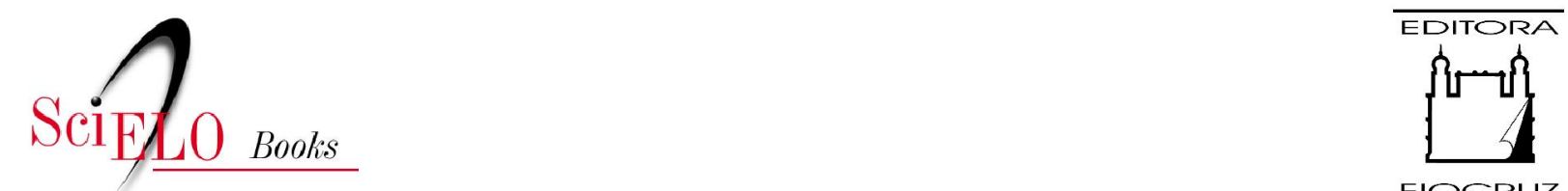

FIOCRUZ

\title{
Interculturalidade, linguagens e formação de professores
}

\author{
Fábio Marques de Souza \\ Simone Dália de Gusmão Aranha \\ (orgs.)
}

\section{SciELO Books / SciELO Livros / SciELO Libros}

SOUZA, F. M., and ARANHA, S. D. G., orgs. Interculturalidade, linguagens e formação de professores [online]. Campina Grande: EDUEPB, 2016, 279 p. Ensino e aprendizagem collection, vol. 2. ISBN 978-85-7879-347-0. Available from: doi: 10.7476/9788578793470. Also available in ePUB from: http://books.scielo.org/id/qbsd6/epub/souza-9788578793470.epub.

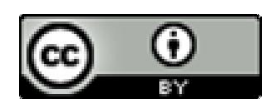

All the contents of this work, except where otherwise noted, is licensed under a Creative Commons Attribution $\underline{4.0 \text { International license. }}$

Todo o conteúdo deste trabalho, exceto quando houver ressalva, é publicado sob a licença Creative Commons Atribição 4.0.

Todo el contenido de esta obra, excepto donde se indique lo contrario, está bajo licencia de la licencia Creative Commons Reconocimento 4.0 . 
\begin{tabular}{l|l} 
Universidade Estadual da Paraíba \\
Prof. Antonio Guedes Rangel Junior | Reitor \\
Prof. Flávio Romero Guimarães | Vice-Reitor
\end{tabular}

\&eduepb $\mid \begin{aligned} & \text { Editora da Universidade Estadual da Paraíba } \\ & \text { Luciano do Nascimento Silva | Diretor } \\ & \text { Antonio Roberto Faustino da Costa | Diretor-Adjunto }\end{aligned}$

Conselho Editorial

Presidente

Luciano do Nascimento Silva

Conselho Científico

Alberto Soares Melo

Cidoval Morais de Sousa

Hermes Magalhães Tavares

José Esteban Castro

José Etham de Lucena Barbosa

José Tavares de Sousa

Marcionila Fernandes

Olival Freire Jr

Roberto Mauro Cortez Motta

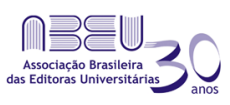

Editora filiada a ABEU

EDITORA DA UNIVERSIDADE ESTADUAL DA PARAÍBA

Rua Baraúnas, 351 - Bairro Universitário - Campina Grande-PB - CEP 58429-500

Fone/Fax: (83) 3315-3381 - http://eduepb.uepb.edu.br - email: eduepb@uepb.edu.br 
FÁBIO MARQUES DE SOUZA

SIMONE DÁLIA DE GUSMÃO ARANHA

(Organizadores)

\section{INTERCULTURALIDADE, LINGUAGENS E FORMAÇÃO DE PROFESSORES}

Coleção Ensino \& Aprendizagem

VOLUME 2

\section{eduepb}

Campina Grande 2016 
Copyright (C) EDUEPB

A reprodução não autorizada desta publicação, por qualquer meio, seja total ou parcial, constitui violação da Lei no 9.610/98.

A EDUEPB segue o Acordo Ortográfico da Língua Portuguesa de 1990, em vigor no Brasil, desde 2009.

Editora da Universidade Estadual da Paraíba

Luciano do Nascimento Silva | Diretor

Antonio Roberto Faustino da Costa | Diretor-Adjunto

Design Gráfico

Erick Ferreira Cabral

Jefferson Ricardo Lima Araujo Nunes

Leonardo Ramos Araujo

Comercialização e distribuição

Danielle Correia Gomes

Layse Ingrid Batista Belo

Divulgação

Zoraide Barbosa de Oliveira Pereira

Revisão Linguística

Antônio de Brito Freire

Elizete Amaral de Medeiros

Normalização Técnica

Antônio de Brito Freire

Jane Pompilo dos Santos

Depósito legal na Biblioteca Nacional, conforme Lei $n^{\circ} 10.994$, de 14 de dezembro de 2004

FICHA CATALOGRAFICA ELABORADA PELA BIBLIOTECA CENTRAL - UEPB

161

Interculturalidade, linguagens e formação de professores [Livro eletrônico]./Fábio Marques de Souza, Simone Dália de Gusmão Aranha (organizadores). - Campina Grande: EDUEPB, 2016

3600 kb. 280 p.; il. (Coleção Ensino e Aprendizagem, V.2).

Modo de acesso: Word Wide Web http://www.uepb.edu.br/ebooks/

ISBN - 978-85-7879-346-3

ISBN EBOOK - 978-85-7879-347-0

1. Ensino aprendizagem. 2. Ensino de literatura. 3. Linguagens 4. Formação de professores. 5. Exclusão social. 6. Livros didáticos. I. Souza, Fábio Marques de. II. Aranha, Simone Dália de Gusmão. III. Título.

EDITORA DA UNIVERSIDADE ESTADUAL DA PARAIBA

Rua Baraúnas, 351 - Bodocongó - Bairro Universitário Campina Grande-PB - CEP 58429-500

Fone/Fax: (83) 3315-3381 - http://eduepb.uepb.edu.br e-mail: eduepb@uepb.edu.br 


\section{Coleção Ensino \& Aprendizagem}

\section{Editores}

Fábio Marques de Souza

Simone Dália de Gusmão Aranha

Daniela Gomes de Araújo Nóbrega

\section{Conselho Científico}

Afrânio Mendes Catani (USP)

Alexsandro da Silva (UFPE)

Carla Luciane Blum Vestena (UNICENTRO)

Cesar Aparecido Nunes (UNICAMP)

Eduardo Gomes Onofre (UEPB)

Iraíde Marques de Freitas Barreiro (UNESP)

José Francisco de Melo Neto (UFPB)

Laura Janaina Dias Amato (UNILA)

Lucinalva Andrade Ataide de Almeida (UFPE)

Luiz Francisco Dias (UFMG)

Maria Helena Vieira Abrahão (UNESP)

María Isabel Pozzo (IRICE-Conicet- UNR, Argentina)

Marta Lúcia Cabrera Kfouri Kaneoya (UNESP)

Mona Mohamad Hawi (USP)

Rosa Ana Martín Vegas (USAL, Espanha)

Selma de Cássia Martinelli (UNICAMP)

Sinara de Oliveira Branco (UFCG) 


\section{Apresentação da Coleção}

A Coleção Ensino \& Aprendizagem visa à publicação e à divulgação de pesquisas desenvolvidas no âmbito do Programa de Pós-Graduação em Formação de Professores da Universidade Estadual da Paraíba - PPGFP/UEPB, assim como investigações de outros programas de pós-graduação do Brasil e do mundo. Os eixos norteadores estão ancorados em duas linhas de pesquisa, a saber: "Linguagens, Culturas e Formação Docente" e "Ciências, Tecnologias e Formação Docente", que subsidiaram as discussões, o desenvolvimento e os resultados das pesquisas realizadas.

Nesta Coleção, várias perspectivas de estudos direcionados a ações pedagógicas entram em cena. A partir dessa postura dialética, o PPGFP vislumbra promover reflexões teóricas e práticas a professores da Educação Básica e do Ensino Superior, que estejam em atividade e em formação inicial e continuada, buscando aperfeiçoar a sua prática docente, por meio de discussões acerca do complexo processo de ensino-aprendizagem. Busca, então, estimular professores, pesquisadores e demais profissionais envolvidos com a Educação e áreas afins, a fomentar um diálogo com a docência e suas práticas interculturais com vistas à produção do conhecimento científico. 


\section{SUMÁRIO}

$9 \quad$ Prefácio

Selma de Cássia Martinelli

13 Apresentação

Fábio Marques de Souza

Simone Dália de Gusmão Aranha

Daniela Gomes de Araújo Nóbrega

17 Interculturalidade e língua: uma experiência em uma Escola Municipal de Foz do Iguaçu-PR Laura Janaina Dias Amato

35 Me llamo Rigoberta Menchú y a mí me necesitó el castellano: a língua espanhola como dispositivo de exclusão social Sandra Leite dos Santos Fernando Zolin-Vesz

49 Pragmática e sociolinguística interacional: contribuições para a formação de professor em línguas materna e estrangeiras Daniela Gomes de Araújo Nóbrega

67 Os processos e critérios de escolha de livros didáticos de português: o que dizem os professores?

Taíza Ferreira de Souza Cavalcanti

Alexsandro da Silva 
103 Análise quantitativa da tradução para o português de expressões idiomáticas nas legendas de fãs do seriado Glee Sinara de Oliveira Branco

Nathalia Leite de Queiroz Sátiro

145 El rol de la mediación estratégica en las arenas de interacción para la potenciación del intercambio lingüístico-cultural

Fábio Marques de Souza

Ana Luzia de Souza

Angela Patricia Felipe Gama

173 Blog e propaganda virtual: uma proposta para a prática de multiletramentos na escola

Simone Dália de Gusmão Aranha

Maria Morganna da Silva Castro

203 Os desafios de educar para o novo contexto de leitura, linguagens e produção da informação Lígia Beatriz Carvalho de Almeida Mariana Pícaro Cerigatto

231 Diseño e implementación de proyectos interculturales en la formación docente María Isabel Pozzo

251 El reto de la educación digital: más allá de la transformación metodológica Rosa Ana Martín Vegas

273 Sobre os autores 


\section{PREFÁCIO}

Este livro vem compor o segundo volume da Coleção Ensino \& Aprendizagem. Nele, participam professores do programa de Pós-Graduação em Formação de Professores da Universidade Estadual da Paraíba e convidados. O primeiro volume, $O$ ensino de literatura hoje: da crise do conceito à noção de escritas, publicado no ano de 2016, pela Editora da Universidade Estadual da Paraíba (EDUEPB), veio inaugurar a proposta desta Coleção e visou promover reflexões teóricas e práticas sobre o processo de ensino-aprendizagem. Esse primeiro volume trouxe como temática central a leitura no contexto da sala de aula e, ao abordar este assunto, o autor questiona o conceito de literatura apresentada nos livros didáticos, o do professor e dos cursos de formação de professores. Dando continuidade à reflexão desencadeada pelo primeiro volume, mas adotando como eixo central de análise o professor, sua didática e sua atividade docente no contexto atual de uma sociedade da comunicação, foi proposto o segundo volume desta Coleção, intitulado Interculturalidade, Linguagens e Formação de Professores.

Tratar do professor, da sua atividade em sala de aula e dos desafios presentes no exercício desta profissão é 
uma tarefa bastante desafiadora e pode ser abordada de diferentes perspectivas. Esta é a proposta desta coletânea de textos que traz como temática central o uso de novas tecnologias digitais da informação e comunicação no contexto da escola. Essas novas formas de comunicação, que começaram a ganhar espaço a partir da segunda metade da década de 1970 e, principalmente, nos anos 1990, proporcionaram maior agilidade na captação e transmissão das informações e tem transformado a maneira dos indivíduos se relacionarem, não só com os conhecimentos, mas entre si. Tal é a intensidade e a velocidade das transformações ocorridas que já não se consegue mais imaginar o funcionamento das sociedades contemporâneas sem o uso dessas tecnologias. Contudo, é importante também assinalar que, embora a inserção no meio digital atinja cada vez mais setores da sociedade, e que esteja cada vez mais globalizada, ainda há uma certa resistência da instituição escolar em incorporar estas novas mudanças no seu fazer pedagógico. Ao contrário de outros setores da sociedade, a escola caminha a passos lentos nesta direção e os avanços são ainda muito tímidos e pouco inovadores.

Apesar de, em termos práticos, a inserção da escola na era digital se dar de maneira mais lenta que os demais setores da sociedade, esta tem sido uma preocupação presente e recorrente, nas últimas décadas, entre os educadores e pesquisadores da educação. Posições favoráveis e contrárias ao uso dessas ferramentas, como mediadoras dos processos de ensino-aprendizagem, têm sido frequente. Há, inclusive, os que acreditam estar aí a solução para alguns dos grandes problemas educacionais, tais como o desinteresse do aluno pela escola, a falta de contextualização e aproximação dos conteúdos ao universo dos alunos, a 
adequação da escola a esse novo tipo de raciocínio presente nos alunos, e que foi desenvolvido com o uso dessas tecnologias, entre outras questões.

É fato que os alunos já não são os mesmos e que se posicionam e reivindicam mudanças nesse formato de escola, e na maneira como conduz o processo de ensino-aprendizagem. Também é fato que essas novas demandas devam atingir diretamente o trabalho que vem sendo realizado pelo professor e sua própria formação. Embora se considere que não seja mais possível retroceder, e que a incorporação dessas inúmeras tecnologias na vida social seja um fato consumado, algumas questões quanto ao seu uso e o modo de fazê-lo, no contexto da educação formal, podem ser diretamente pontuadas.

A escola está preparada para incorporar e implementar o uso dessas novas tecnologias de maneira a não ser somente usuária desses recursos, mas usá-los como mediadores na construção de propostas que permitam avançar nesse modelo de ensino que já se encontra sedimentado? Quais seriam os caminhos necessários para que o professor pudesse apropriar-se dessas novas possibilidades postas pelo uso das tecnologias e ser um usuário participativo? Quanto o uso dessas novas tecnologias pode efetivamente contribuir para uma educação mais eficiente e de melhor qualidade, e como se pode atingir esta meta?

Essas são apenas algumas questões que precisariam ser pautadas dentro de temática tão abrangente e que atinge diretamente o trabalho do professor, que por sua vez remete a uma situação anterior a este próprio trabalho, e que diz respeito à formação docente. Essas questões apresentam-se, de forma direta ou indireta, nos diversos 
capítulos deste livro e nas discussões teóricas e nas propostas apresentadas pelos autores. À sua maneira, cada um dos autores coloca em evidência a sua preocupação e o seu interesse em investigar e refletir, não somente sobre o uso de novas tecnologias, mas também sobre o fazer docente. Essa nova possibilidade de olhar e pensar a educação, dentro de uma perspectiva em que se inserem novas linguagens digitais, multiletramentos, integração e trocas interculturais, torna-se cada vez mais emergente, $\mathrm{o}$ que faz ser esta coletânea de textos atual e pertinente.

A proposta de reflexão, apresentada nesta obra, nos chama para um diálogo mais direto, propositivo e integrado entre alguns dos pilares da educação, tais como a formação docente, a instituição escolar, o fazer docente e discente e estas novas formas de se relacionar e se apropriar de novos conhecimentos.

Dra. Selma de Cássia Martinelli Programa de Pós-Graduação em Educação

Faculdade de Educação da Unicamp Departamento de Psicologia Educacional 


\section{APRESENTAÇÃO}

No segundo volume da Coleção Ensino E Aprendizagem, várias perspectivas de estudos direcionados à prática pedagógica entram em cena. Sobre o aprendizado das línguas em uso e trocas culturais em contextos multilíngues ou bilíngues existentes nas fronteiras, nos deparamos com o capítulo de Laura Janaina Dias Amato (UNILA/PPGIELA), Interculturalidade e língua: uma experiência em uma escola municipal de Foz do Iguaçu-PR. A partir da análise de excertos da biografia de Rigoberta Menchú, intitulada Me llamo Rigoberta Menchú y así me nació la conciencia, Sandra Leite dos Santos (PG-UFMT/PPGEL) e Fernando ZolinVesz (UFMT/ PPGEL) discorrem sobre a constituição do espanhol como dispositivo de exclusão social, além do estabelecimento das relações de poder por meio do (não) conhecimento da língua no contexto da Guatemala.

Com o título, Pragmática e Sociolinguística interacional: contribuições para a formação de professor em linguas materna e estrangeiras, Daniela Gomes de Araújo Nóbrega (UEPB/PPGFP) argumenta como as teorias Pragmática e Sociolinguística interacional podem ser de grande valia para descrever e analisar a função das várias linguagens (verbal e não verbal) usadas em sala de aula e das suas 
implicações tanto para a prática pedagógica do professor de línguas materna e estrangeiras como para a aprendizagem do aluno.

No texto Os processos e critérios de escolha de livros didáticos de português: o que dizem os professores? Taíza Ferreira de Souza Cavalcanti (PG-UFPE/PPGEduc) $e$ Alexsandro da Silva (UPFE/PPGEduc) investigaram como ocorreu o processo de escolha do livro didático de português em uma escola da rede estadual de ensino de Pernambuco, situada no município de Arcoverde-PE, e os critérios que os docentes consideraram ao realizarem suas escolhas. Ancoradas nos estudos da tradução, Sinara de Oliveira Branco (UFCG/POSLE) e Nathalia Leite de queiroz Sátiro (PG-UFCG/POSLE - UEPB), no capítulo Análise quantitativa da tradução para o português de expressões idiomáticas nas legendas de fãs do seriado Glee, asseveram que a atividade de tradução de legendas de seriados de TV pode não somente servir como material para cursos de tradução e insumo para pesquisa, mas também para ajudar aprendizes e professores de línguas a observarem o uso da língua através do meio audiovisual, justificando a importância desta investigação.

Outros artigos têm como eixo norteador de discussão o uso das ferramentas tecnológicas (TDICs) no ambiente de ensino na educação básica e suas implicações para diversas categorias de ensino/aprendizagem.

Os autores Fábio Marques de Souza (UEPB/PPGFP UFPE/PPGEduc), Ana Luzia de Souza (PG-UEPB/PPGFP - IFPB) e Angela Patricia Felipe Gama (PG-PUCSP/COS), no capítulo El rol de la mediación estratégica en las arenas de interacción para la potenciación del intercambio lingüistico-cultural, discutem o papel das TDICs na mediação a 
partir do intercâmbio linguístico-cultural entre aprendizes de português e espanhol como línguas adicionais via Teletandem - uma atividade colaborativa entre a UEPB, UFPE, IFPB, UNILA, UNR e o Instituto de Idiomas de Salta (Argentina).

Por sua vez, Simone Dália de Gusmão Aranha (UEPB/ PPGFP) e Maria Morganna da Silva Castro (PG-UEPB/ PPGFP) no capítulo Blog e propaganda virtual: uma proposta para a prática de multiletramentos na escola, consideram a hipótese de que o uso do blog na sala de aula contribui para a prática de multiletramentos. Tendo como enfoque teórico a Pedagogia dos Multiletramentos, as autoras lançam uma proposta didática, desenvolvida a partir de uma sequência didática, utilizando o blog como ferramenta na dinamização de atividades escolares com o gênero discursivo propaganda que habita o espaço virtual.

Em Os desafios de educar para o novo contexto de leitura, linguagens e produção da informação, Lígia Beatriz Carvalho de Almeida (UFCG) e Mariana Pícaro Cerigatto (PG-UNESP) discorrem sobre o novo papel do leitor, sua identidade leitora e um consequente novo fazer docente, frente a um novo paradigma de leitura em ambientes virtuais do século XXI. Seguindo o mesmo viés do uso das TDICS, desta vez em ambiente a distância e presencial, Maria Isabel Pozzo (UNR/CONICET), no capítulo Diseño e implementación de proyectos interculturales en la formación docente, descreve propostas pedagógicas de uma equipe argentina que vincula professores e estudantes de ensino superior com alunos de várias nacionalidades com o uso das novas tecnologias, com intuito de promover uma maior competência intercultural entre eles. 
Ainda sobre o uso das TDICS na Educação, Rosa Ana Martín Vegas (USAL/MUPES), com o texto El reto de la educación digital: más allá de la transformación metodológica, discute a eficácia desse novo modelo de metodologia voltado para o ensino com base na análise das deficiências na sua implementação atual, herdada, em grande parte, da inércia de um modelo educacional tradicional e difícil de superar.

Através desses capítulos, que compõem este segundo volume da Coleção Ensino \& Aprendizagem, que o PPGFP vislumbra promover reflexões teóricas e práticas, aos professores da Educação Básica, do Ensino Superior e demais interessados, para o seu exercício profissional, buscando aperfeiçoar a sua prática docente, por meio da compreensão e potencialização do complexo processo de ensino-aprendizagem e da construção do conhecimento e a intervenção desses profissionais nos cenários local, regional, nacional e internacional, rumo às práticas interculturais.

Boa leitura!

Fábio Marques de Souza Simone Dália de Gusmão Aranha Daniela Gomes de Araújo Nóbrega 


\title{
INTERCULTURALIDADE E LÍNGUA: Uma experiência em uma Escola Municipal de Foz do Iguaçu
}

Laura Janaina Dias Amato (UNILA)

\begin{abstract}
O Ministério da Educação do Brasil, em parceria com os Ministérios de Educação de países vizinhos e com as Secretarias Estaduais e Municipais de Educação, realizam o chamado: Programa Escolas Interculturais de Fronteira (PEIF).

O Programa é desenvolvido no que se convencionou chamar de Escolas Interculturais de Fronteira, em cidades brasileiras da faixa de fronteira de um lado e em suas respectivas cidades gêmeas de países que fazem fronteira com o Brasil, de outro. Seu objetivo principal é o de promover a integração regional por meio da educação intercultural, considerando contextos multilíngues ou bilíngues existentes nas fronteiras, tendo como consequência a ampliação das oportunidades do aprendizado das línguas em uso e trocas culturais.

Foz do Iguaçu, no Paraná, integra o Programa desde seu início, em 2005. A escola municipal Adele Zanotto Scalco faz parceria direta - chamada escola-espelho - com
\end{abstract}


a Escola Bilíngue $\mathrm{n}^{\circ} 2$ em Puerto Iguazú, na Argentina, onde semanalmente professoras de ambas as escolas atravessam a fronteira - fazem o chamado cruze - para lecionar em sua língua materna conteúdos previamente acordados entre as professoras regentes e as professoras do cruze. A metodologia de trabalho do Programa está descrita no acordo interministerial assinado em 2008 entre Brasil e Argentina, nele está determinado que as professoras e as turmas participantes do Programa deverão utilizar a metodologia de projetos de aprendizagem, desta forma, a partir do levantamento de interesse temático da turma, um tema é escolhido por todos e desenvolvido pela professora ministrante. Assim, um tema como, por exemplo, futebol é desenvolvido na língua materna da professora e ela deverá executá-lo a partir de questionamentos feitos pelas crianças da turma. Ao final de 8 encontros, um projeto poderá ser apresentado. Assim, crianças brasileiras junto com uma professora argentina aprendem sobre um tema de interesse deles, mas na língua outra.

O Programa visa sensibilizar o aluno linguística e interculturalmente e não torná-lo proficiente na língua (MINISTERIO; MINISTERIO, 2008), de tal maneira privilegia-se a formação cidadã crítica e o reconhecimento das diferenças são pontos fundamentais no Programa.

Não podemos esquecer que Foz do Iguaçu se localiza em uma fronteira TRInacional e que apesar da escola brasileira ter como parceira uma escola argentina, estes alunos também tem contato com o Paraguai ${ }^{1}$ e moram em

1 Após conversa com escola e alunos, descobriu-se que muitos pais trabalham no comércio paraguaio e alguns falam guarani com seus filhos. 
uma cidade multicultural, permeada pelo encontro de diversas culturas e etnias e por diferentes ações e interpretações multilinguísticas e pluriculturais.

É sabido que cada cultura traz valores específicos e parâmetros pré-definidos singulares que são tomados pelo e através do social. A experiência de vivenciar e discutir temas de interesse em um grupo multicultural ${ }^{2}$ pode favorecer nos processos de construção da alteridade e desensibilização dos participantes levando a um ganho considerável no tocante a compreensão do Outro, porque a troca de experiências é considerada um ponto alto no processo que contribui para a construção da cidadania crítica. Assim, ao trabalhar com o resgate de brincadeiras, músicas, contos e parlendas mostra ao aluno que as culturas são sócio-historicamente construídas, fazendo assim um paralelismo com o descentramento do sujeito, ou seja, as culturas e os sujeitos são sócio-historicamente construídos e assim tornam sujeitos ou assujeitados, dependendo da forma na qual abordamos a noção de leitura e conhecimento de mundo.

Tendo em vista o exposto, foi realizado entre os anos de 2014 e 2015 um projeto de extensão universitária cujos objetivos eram: (1) resgatar aspectos culturais de países da América Latina, (2) sensibilizar alunos da Escola Municipal Adele Zanotto Scalco, e (3) aproximar a comunidade de pais e professores para desconstruírem estereótipos formados sobre a América Latina. Estudantes da Universidade Federal da Integração Latino-Americana (UNILA), orientados pela coordenadora do projeto,

2 Aqui, multicultural não abrange somente as culturas nacionais. 
ministravam atividades ${ }^{3}$ nas turmas que não recebiam a visita das professoras argentinas, com o objetivo de equalizar as relações linguístico-culturais entre as escolas brasileira e argentina. Tendo em vista que o documento do Programa informa que as relações de poder são diferentes entres os falantes de português em relação ao espanhol (MINISTERIO; MINISTERIO, 2008); assim, ao oportunizar um contato com outras culturas, alunos, pais e professores poderão se sensibilizar e atuar de forma crítica e reflexiva. Desta forma, transformando a escola e a comunidade envolvida em um ambiente intercultural.

Como o projeto tem perspectiva a médio e longo prazo, para compreender se havíamos atingido parcialmente nossos objetivos, fizemos relatórios de autoavaliação dos estudantes universitários integrantes do projeto e apresentamos aos alunos da escola dois questionários: um ao início e outro ao final do projeto. Neste texto apresentamos uma breve análise do material recolhido no ano de 2015.

\section{De onde partimos ...}

O projeto executado tem como principal base epistemológica o letramento crítico. Partindo de um ponto de vista ontológico esta perspectiva parte do entendimento de que a realidade não é algo que possa ser concretamente capturada e conhecida definitivamente. Nesta visão, a realidade não existe fora do sujeito; ela está intrinsecamente ligada a ele. Assim, a realidade é construída a partir do

3 As atividades eram vídeos, músicas, contação de história, pinturas, entre outras. $\mathrm{O}$ foco estava na cultural e não na língua. 
olhar do observador (MATURANA, 2006) e pela linguagem, sendo ela determinada histórica, social, política, ideológica e discursivamente; e desta forma não é possível conceber a existência de uma única realidade, mas sim de realidades apreendidas a partir do olhar do observador.

Ao não dissociarmos a realidade do olhar do observador, compreendemos que há diferentes realidades possíveis e legítimas, porque são construídas por uma linguagem que é formada através de uma concepção histórica, social e política. Sendo assim, vivemos concomitantemente com várias realidades possíveis e sócio-culturalmente construídas.

O letramento crítico compreende que todo conhecimento é ideologicamente marcado e regido por regras discursivas que são estabelecidas pelas relações de poder nos contextos operados, sendo assim, conforme Shor:

O letramento crítico [deixa] clara a ligação entre conhecimento e poder. Ele [apresenta] o conhecimento como construto social ligado a normas e valores, e [demonstra] modos de crítica que iluminam como (...) o conhecimento serve interesses econômicos, políticos, e sociais bastante específicos (SHOR, 1997).

Destarte, a necessidade de investigação e conhecimento do contexto e dos partícipes do projeto antes da aplicação das atividades específicas. O objetivo das atividades, assim como do letramento crítico, é questionar o status quo para apresentar e pensar caminhos alternativos 
de desenvolvimento pessoal e social, e no caso das atividades desenvolvidas resgatando e valorizando a história e a identidade latino-americana da qual as crianças pertencem.

Fazer uso do letramento crítico é, segundo Shor (op. cit.), "[fazer] o uso da linguagem que questiona a construção social do sujeito, [pois quando agimos dentro do desse paradigma] (...) examinamos nosso desenvolvimento contínuo para revelar as posições subjetivas das quais entendemos o mundo e agir nele." Assim sendo, o sujeito é figura central no processo de (trans)formação do seu contexto a partir do seu próprio discurso, uma vez que o letramento crítico prima pelo desenvolvimento de uma consciência crítica do sujeito sobre si mesmo e sobre os contextos dos quais faz parte, permitindo a ele "refazer suas próprias identidades e realidades sócio-políticas através de seus próprios processos de compreensão e através de suas ações no mundo" (CERVETTI; PARDALES; DAMICO, 2001).

Segundo Martins (2007):

Agir dentro do paradigma do letramento crítico é agir dentro da "objetividade entre parênteses" de Maturana (2001, p.31-42), em que a existência de diferentes realidades legítimas, determinadas pelo olhar do observador, abre um espaço de convivência no qual há um respeito pelos entendimentos de mundo diferentes, e não uma completa negação da legitimidade do outro. Agir 
dentro do paradigma do letramento crítico significa se colocar numa posição de questionamento constante, investigando a si mesmo e aos outros a fim de entender os pressupostos e implicações dos nossos entendimentos e dos entendimentos dos outros. Em outras palavras, este processo de reflexão crítica nos leva a querer compreender de onde vêm e para onde nos levam as nossas visões de mundo (MARTINS, 2007, p.19-24).

Partindo de uma perspectiva de que convivemos em ambientes multiculturais e de perspectivas diversas, recuperar temas tradicionais e apresentá-los de forma não folclorizada, teve como objetivo apresentar novas e diferentes leituras de mundo, novas perspectivas de ver o Outro e para assim poder transformar perspectivas e abrir caminhos diferentes para a compreensão do Outro e para a construção da alteridade.

Esta permanente disponibilidade de estar aberto a outras leituras de mundo, de viver dentro do caminho da "objetividade entre parênteses" de Maturana (2006), faz com que estejamos um pouco mais conscientes de que somos seres sociais, culturais e históricos, ou seja, que somos uma "costura de posição e contexto", logo, parciais e incompletos. Conscientes disso, assumimos um posicionamento mais crítico em relação a nós mesmos e aos outros, e, dessa maneira, o aprender passa a ser uma maneira de construir o mundo, e não uma forma de se adaptar a ele. A capacidade de construir (e reconstruir) a 
realidade é para Freire (1996, p.77) “Tarefa incomparavelmente mais complexa e geradora de novos saberes do que simplesmente a de nos adaptar a ela." No entanto, esta tarefa não deve ser movida por uma "curiosidade ingênua", que não problematiza os saberes existentes para a geração de novos saberes, mas sim por uma "curiosidade epistemológica" (Ibid., p.31), que envolve um processo de critização, e que "nos põe pacientemente impacientes diante do mundo [e de nós mesmos]" (Ibid., p.32).

\section{Como fizemos...}

Com a base epistemológica e ontológica acima descrita, iniciamos o projeto, pensando em contribuir não só na formação linguística-cultural, mas também na formação de cidadãos abertos e críticos que poderão se relacionar de modo mais flexível e respeitoso em outros contextos socioculturais; selecionamos turmas da Escola Municipal Adele Zanotto Scalco que não recebem a visita das professoras argentinas 4 . Devido a diferença do quantitativo de turmas entre as escolas e o número de professoras que atuam em ambas, não é possível atender todas as turmas da escola brasileira. O cruze ocorre geralmente com duas professoras de cada escola e é realizado em dias alternados. Quando o cruze acontece, a professora regente permanece em sala e a professora visitante ministra a aula. São oito encontros, nos quais são desenvolvidos o projeto e o tema escolhido pelos estudantes. Os temas

4 Aqui sempre mencionaremos no feminino, tendo em vista o número majoritário de mulheres como profissionais da educação básica. 
são os de interesse dos alunos e após a definição de um dos temas citados eles fazem perguntas sobre o mesmo e estas serão respondidas nos encontros subsequentes. $\mathrm{O}$ trabalho é realizado através da metodologia de projetos, culminando, ao final dos encontros, com a apresentação do mesmo. $\mathrm{O}$ primeiro planejamento sempre ocorre em conjunto: a professora do cruze e a professora regente discutem sobre o interesse da turma e sobre o conteúdo programático executado pela professora regente, para que desta forma a professora do cruze pudesse, na medida do possível, adequar o tema escolhido pelas crianças ao conteúdo programático obrigatório.

Como geralmente são duas professoras de cada país que participam do cruze, são atendidas no máximo quatro turmas por cada professora. Na Argentina, esta quantidade de professoras equivale ao total de turmas da escola integrante do Programa, mas no Brasil ficam turmas desassistidas. Como o objetivo do Programa é transformas a escola, como um todo, em uma escola intercultural, o projeto de extensão desenvolvido pela docente da UNILA veio auxiliar a escola no cumprimento deste objetivo ao levar uma proposta de trabalho com língua e cultural nas turmas não assistidas pelas professoras argentinas do Programa.

\section{Porquê fizemos...}

A educação crítica e reflexiva faz-se necessária hoje, principalmente por estarmos em mundo fluído e em constante mutação. Atualmente, a mobilidade física e digital nos permite um contato com o (não tão) distante. Assim, as distâncias tornam-se virtuais e as tradições acabam 
sendo secundárias, pois privilegia-se o saber científico e as novas tecnologias.

O projeto pretendia então contribuir para (1) o resgate de brincadeiras, músicas e histórias tradições da América Latina, (2) aproximar os saberes das crianças da Escola Municipal Adele Zanotto Scalco com a produção dos saberes de crianças de outros países da América Latina, (3) contribuir para a desconstrução de estereótipos frente a cultura latino-americana e a língua espanhola.

Assim, o projeto teve a intenção de contribuir para uma formação crítica, permitindo que os alunos tomem conhecimento de uma perspectiva flexível e contextualizada perante o Outro, além de explorar a diversidade sociocultural e respeitando as premissas das quais cada um parte.

Além disso, o letramento crítico propõe-se formar cidadãos críticos e que primem pela construção colaborativa de saberes, desenvolvendo habilidades de uma leitura de mundo ampla e questionadora.

Desta forma propusemos como objetivo geral a valorização da interação e comunicação recíprocas, entre os diferentes sujeitos e grupos culturais favorecendo a desconstrução de preconceitos e discriminações presentes na cultura latina-americana, além disso almejávamos: promover relações dialógicas entre pessoas e grupos que pertencem a culturas diferentes; apreciar e respeitar cada um com as suas diferenças e similaridades; motivar positivamente para o aprendizado de uma segunda língua a partir do contato com falantes nativos; desenvolver uma sistemática de trabalho de sensibilização dos pais e professores para o desenvolvimento de atitudes positivas frente ao bilinguismo e à interculturalidade; reconhecer as 
características próprias, o respeito mútuo e a valorização do diferente como "diferente".

\section{O que fizemos...}

Diferentemente do foco do PEIF, trabalhando questões culturais na fronteira onde as escolas estão localizadas, o projeto de extensão visou todo o continente latino-americano e para tanto foi realizado um trabalho de pesquisa bibliográfica por país, no qual os participantes deverão buscar músicas, contos e brincadeiras tradicionais infantis e conhecer seu contexto de criação e aplicação.

As músicas, contos e brincadeiras foram devidamente didatizadas e ao final de cada aplicação na turma, foi organizado um portfólio por turma com as atividades desenvolvidas. Além disso, os alunos da escola foram envolvidos em atividades temáticas (Dia das Mães, Dia dos Pais, etc), sempre relacionando a mesma atividade festiva em algum país da América Latina, desde forma, pode-se, por exemplo, trabalhar o México em novembro com o tema Finados.

Todas as atividades eram planificadas com o aval da coordenadora do projeto e da regente da turma na qual a respectiva atividade seria ministrada, além disso, a regente da turma era envolvida não só no planejamento geral, mas também na execução do trabalho.

A escolha dos países não foi aleatória. A intenção era conectar tema - data comemorativa - país, desta forma escolhemos, por exemplo, para o mês de maio a Argentina e resolvemos trabalhar o Dia das Mães, para o mês de abril, com o feriado de Tiradentes no Brasil, escolhemos 
a Venezuela e Simón Bolivar. Pesquisamos histórias, lendas e músicas populares relacionados a tríade indicada e com isso iniciávamos o planejamento e a didatização das atividades. Sempre de modo lúdico, uma vez por semana, as aulas eram feitas em língua espanhola e duravam trinta minutos. A colaboradora apresentava o mapa da América Latina e localizava, junto com os estudantes, o país a ser trabalhado, com seu respectivo mapa. Para cada país era dedicado um mês completo, ou seja, quatro encontros e esses encontros eram divididos entre (a) apresentação do país e tema, (b) desenvolvimento, (c) discussão e (d) fixação do tema.

Para tentar compreender o alcance das ações planejadas, foram realizados dois questionários, um no início (1) da execução do projeto e outro na finalização (2) do mesmo. As perguntas do questionário (1) foram:

(1.a) Você conhece quais os países fazem fronteira com o Brasil? Se sim, quais?

(1.b) Você sabe que línguas eles falam nestes países?

(1.c) O que você conhece sobre estes países?

(1.d) O que você gostaria de conhecer destes países?

(1.e) Você acha que eles têm costumes e histórias diferentes das nossas?

O segundo questionário foi mais sucinto e serviu também para avaliar a atuação da colaboradora do projeto, sendo que as perguntas relacionadas diretamente ao projeto eram:

(2.a) O que você mais gostou das aulas?

(2.b) Qual país você gostaria de conhecer? 
O número de crianças que responderam cada questionário foi variável entre o primeiro e o segundo, por isso aqui só analisaremos parte das respostas absolutas e de maneira qualitativa. $\mathrm{O}$ projeto foi executado em três turmas do $3^{\circ}$ ano, crianças com idade entre 7 e 9 anos.

\section{Será que deu certo?}

Analisando as repostas das crianças pudemos perceber que a fronteira próxima é bem conhecida, sendo lembrado como resposta a (1.a) os países vizinhos a cidade de Foz do Iguaçu, mas também foi possível observar que para as crianças não havia uma diferença concreta entre país e cidade, pois não sabiam distinguir um do outro e por isso alguns citaram outras localidades, principalmente cidades comumente citadas na mídia como Rio de Janeiro e São Paulo e cidades nas quais possam ter algum vínculo afetivo, como o caso de Toledo (PR). Ao compararmos a resposta de (1.a) com a resposta de (2.b) pudemos perceber que já se distinguia país de cidade; além disso foram citados outros países da América Latina. Entendemos que o conteúdo da pergunta é diferente, mas como para as crianças em (1.a) não houve necessariamente a compreensão do conceito de "país fronteiriço", supomos também que em (2.b) outros países, além dos comumente citados Paraguai e Argentina fossem aparecer e tal fato ocorreu quando vimos que catorze crianças citaram que gostariam de conhecer o México, por exemplo.

As respostas à pergunta (1.d) não direcionam unicamente a ponto turístico famoso ou a algum monumento. As crianças querem conhecer o cotidiano dos outros países e citam que gostariam de conhecer as lojas, as pessoas, as 
escolas dos outros países. Percebe-se também que a própria cidade é desconhecida para as crianças, pois as mesmas citam locais no próprio município, como o Parque das Aves e Itaipu. Desta forma inferimos que a maioria das crianças não está preocupada com o que poderia ser diferente, mas sim com o igual. Elas querem participar e compreender este cotidiano do Outro, pois é o mesmo que o seu.

Quando observamos as respostas de (1.c) ficamos admirados com as mesmas, pois pudemos perceber que algumas crianças tinham parentes e contato com pessoas de outros países (não foram citados os países). Mais uma vez o cotidiano foi mencionado, muitas citaram que conheciam: casas, lojas, carros, pessoas, comidas, salão de cabeleireiro, entre outros. Desta forma, aquilo que achávamos que poderia estar distante da criança, na realidade era mais comum e rotineiro do que pensávamos. Com isso o trabalho foi direcionado em sempre buscar da criança o conhecimento prévio sobre o país e conteúdo a ser abordado.

Da mesma forma (2.a) nos mostrou o quão efetivo foi o trabalho mensal de cada país, pois mesmo em dezembro as crianças lembraram da primeira atividade feita, em março. Assim como várias outras atividades realizadas no primeiro semestre. Estas respostas também revelaram que o caráter lúdico do projeto foi reconhecido, com destaque para as aulas que tinham filmes e desenhos para colorir. Cabe destacar que dentre as respostas das crianças muitas estavam com palavras em espanhol. 


\section{E agora?}

As diversidades linguístico-cultural dos países latino-americanos tiveram um papel de destaque na execução do projeto, diferente da função das ações do PEIF.

No projeto de extensão estávamos preocupados em integrar numa discussão intercultural as turmas não participantes do PEIF e assim transformar a escola em um ambiente intercultural, no qual alunos, pais e professores pudessem se sentir valorizados e respeitados pela e com a sua própria cultura.

Pensamos aqui uma educação intercultural que vai além do aprendizado da e pela língua, mas uma educação com princípios morais e éticos, na qual a criança educanda é tomada como um ser completo, com necessidades e características que devem ser respeitadas. Por isso os conteúdos trabalhados foram construídos pensando não em uma transmissão rígida de conteúdos específicos, mas em algo lúdico e próximo à realidade infantil.

Segundo Kaikkonen (2007) “Encontros interculturais são pessoais e individuais, mas também tem seu caráter coletivo." Esse caráter coletivo é construído pela sua própria língua e cultura, assim aproximar uma cultura "estrangeira" da sua própria faz com que conflitos apareçam, mas os mesmos são minimizados através de um olhar crítico e reflexivo sobre a cultura do Outro e a sua própria.

Assim, conteúdos apresentados de forma crítica, lúdica e diversificada podem contribuir para a aproximação com Outro e (re)construindo realidades conjuntas e semelhantes. Não com o foco do diferente, mas no igual. 
Desta forma, crianças entre sete e nove anos puderam discorrer e aprender mais sobre si e sobre outras crianças que poderiam estar fisicamente distantes, mas são unidas pelas histórias semelhantes que possuem.

\section{REFERÊNCIAS}

ARONOWITZ, S.; GIROUX, H. Education under siege. South Hadley, MA: Bergin Garvey, 1985. p.132.

CERVETTI, G.; PARDALES, M.J.; DAMICO, J.S. A tale of differences: comparingthe traditions, perspectives, and educational goals of critical reading and critical literacy. Disponível em: <http://www.readingonline.org/articles/cervetti/index.html>.

FOUCAULT, M. A ordem do discurso. 8.ed. São Paulo: Edições Loyola, 2002.

FREIRE, P. Pedagogia da autonomia: saberes necessários à prática educativa. 34. ed. São Paulo: Paz e Terra, 1996.

KAIKKONEN, P. Interkulturelles Lernen in einem multikulturellen Europa - Fremdsprachliches Lernen im Spannungsfeld. In: ANNEGRET, H.; KREIENBAUM, M. A. (Orgs) Europakompetenz - durch Begegnung lernen. Europa: Barbara Budrich, Opladen \& Farmington Hills, 2007.

MARTINS, L. L. Os espaços abertos: uma investigação sobre a metodologia em um curso de conversação avançada em língua inglesa. Monografia em Letras. Curitiba: UFPR, 2007. 
MATURANA, H. Biologia do conhecer e epistemologia. In: _. Cognição, ciência e vida cotidiana. Belo Horizonte: Editora UFMG, 2006. p.19-124.

MINISTÉRIO DA EDUCAÇÃO; MINISTERIO DE EDUCACIÓN, CIENCIA Y TECNOLOGÍA. Escolas de fronteira. Brasília e Buenos Aires: Secretaria de Educação Básica e Dirección Nacional de Cooperación Internacional, 2008.

SHOR, I. What is critical literacy? Disponível em: http:/ / www.lesley.edu/journals/jppp/4/shor.html. Acesso em: nov. 2005. 


\title{
ME LLAMO RIGOBERTA MENCHÚ Y A MÍ ME NECESITÓ EL CASTELLANO': A língua espanhola como dispositivo de exclusão social ${ }^{2}$
}

Sandra Leite dos Santos (UFMT)

Fernando Zolin-Vesz (UFMT)

\begin{abstract}
"Se aprendió el lenguaje del colonizador, no para integrarse a una historia que nunca la incluyó, sino para hacer valer, mediante la palabra, una cultura que es parte de esa historia" (Elizabeth Burgos).
\end{abstract}

1 Empregamos esta construção como metáfrase do título da obra aqui analisada - Me llamo Rigoberta Menchú y así me nació la conciencia. Como será discutido no capítulo, o castelhano constitui dispositivo de exclusão social. Daí a necessidade, na perspectiva de Rigoberta Menchú, de aprendê-lo.

2 Este capítulo se refere à pesquisa de mestrado do primeiro autor, em andamento no Programa de Pós-Graduação em Estudos de Linguagem (PPGEL), da Universidade Federal de Mato Grosso (UFMT), sob orientação do segundo autor. 
Nascida na Guatemala, Rigoberta Menchú Tum tornou-se conhecida depois da publicação, em 1985, do livro Me llamo Rigoberta Menchú y así me nació la conciencia, escrito por Elizabeth Burgos. A obra narra o despertar da consciência de Menchú para a situação de injustiça social, política e econômica que a cercava: já aos sete anos de idade, começa a questionar as condições em que os indígenas de sua comunidade eram transportados para os trabalhos nas fazendas - pessoas e animais misturados em caminhões fechados, sem ventilação ou qualquer tipo de higiene.

O maior objetivo de Menchú passa a ser, dessa forma, aprender espanhol para que ela e sua comunidade possam ter acesso aos bens sociais que lhes são negados, pelo próprio Estado, em função do não conhecimento do caste1 hano ${ }^{3}$. Grande parte da população indígena guatemalteca, segundo Menchú, não possuía acesso ao espanhol, sobrelevado à língua oficial naquele país. Sua aprendizagem se torna, para Rigoberta, uma questão de sobrevivência e de resistência: a única maneira de enfrentar a exclusão social seria, inicialmente, vencer a barreira linguística para, em seguida, as demais instâncias sociais de segregação das comunidades indígenas da Guatemala.

3 Empregamos as formas "castelhano" e "espanhol/língua espanhola" como sinônimos da língua de prestígio - e, portanto, dispositivo de exclusão social - imposta à Guatemala pela Espanha ainda no período colonial. Tomamos como parâmetro o próprio histórico da constituição do castelhano como língua oficial da Espanha: de uma variedade restrita a uma exígua região geográfica do norte do país até sua conversão em idioma oficial de toda uma nação e sua chegada ao Novo Continente como língua dos colonizadores (MOURE, 2015). 
O intuito desta investigação é, portanto, analisar, no advento da personagem em sua busca pela aprendizagem do castelhano, a língua como um dispositivo de exclusão social. Inicialmente, discutimos o contexto sócio-histórico da Guatemala, abordando alguns aspectos da colonização do país pela Espanha, em especial os linguísticos, conforme Böckler (2001) e Böckler e Herbert (2002). Em seguida, trazemos à baila o conceito foucaultiano de dispositivo, ladeado por autores que complementam a discussão, como Júnior e Sousa (2014) e Carvalho e Sargentini (2014). Por fim, analisamos excertos da biografia de Rigoberta Menchú, buscando evidenciar, em sua narrativa, a constituição do espanhol como dispositivo de exclusão social e, por conseguinte, o estabelecimento das relações de poder por meio do (não) conhecimento da língua.

\section{A herança linguístico-colonial da Guatemala}

A Guatemala, assim como outros países da América Latina, foi colonizada pela Espanha. No decorrer desse processo, os índios foram obrigados a viver separados dos espanhóis, em locais afastados, conforme observa Böckler: "En los perímetros urbanos se ubicó a la población autóctona en barrios segregados, de los cuales sólo podría salir para efectuar los trabajos que se le encomendados, así como para asistir las ceremonias religiosas cristianas" (BÖCKLER, 2001, p.13).

Ainda segundo o autor, "las relaciones sociales cotidianas de la población colonial nacen marcadas por las desigualdades en todos os niveles. No es un simple problema de distribución arbitraria e injusta de las riquezas" (Ibid., p.15). Nesse contexto, o castelhano adquire estatuto 
de língua oficial, atribuindo ao não falante uma posição inferior. A exclusão, portanto, também resulta da condição de superioridade conferida aos falantes da língua oficial em detrimento daqueles não falantes.

A questão da desigualdade social, que aflige as comunidades indígenas da Guatemala e perdura até os dias atuais - como nos narra a biografia de Menchú -, parece constituir-se como herança do processo de colonização estabelecido pela Espanha, corroborando o que Grosfoguel (2008) denomina colonialidade, ou seja, “a continuidade das formas coloniais de dominação após o fim das administrações coloniais, produzidas pelas culturas coloniais e pelas estruturas do sistema-mundo capitalista moderno/colonial" (GROSFOGUEL, 2008, p.126). Assim, relações de exploração e de exclusão dos indígenas ainda persistem na recente história da Guatemala, agora materializadas por meio da figura do ladino4: "La relación de explotación existente del ladino para con el indígena constituye la contradicción dominante en las estructuras de clases. El ladino monopoliza la tierra de alta productividad [...]; explota mano de obra indígena; monopoliza el crédito agrícola" (BÖCKLER; HERBERT, 2002, p.109).

De igual modo, a língua trazida pelo colonizador, alçada ao posto de oficial do país, prevalece, preservando relações de marginalização estabelecidas desde o período colonial. As comunidades indígenas do Altiplano, região montanhosa da Guatemala onde Menchú e sua família viviam, sofreram incessantemente com essa segregação: por não

4 São denominados ladinos os guatemaltecos que resultaram da miscigenação entre espanhóis e indígenas desde o período colonial. 
possuírem autoridade frente ao castelhano, tornaram-se passíveis de exploração por parte dos coronéis do café e do algodão. Nas fazendas, deparavam-se com diversas doenças e com a morte, em decorrência da fome e das péssimas condições de trabalho, o que dizimou parcela significativa de índios guatemaltecos. Além disso, a pouca terra que possuíam para cultivar era invadida e tomada pelo governo e pelos fazendeiros. Nessa seara, Menchú passa a entender a aprendizagem da língua espanhola como necessidade, como forma de sobrevivência e de resistência ao status quo de uma sociedade em que não estava inclusa.

\section{O conceito de dispositivo}

De acordo com Júnior e Sousa (2014), o termo dispositivo é um conceito foucaultiano relativo a "técnicas, estratégias e formas de assujeitamento postas em ação pelas relações de poder" (FERNANDES JÚNIOR; SOUSA, 2014, p.14). Para esclarecer o sentido do termo, os autores buscam em Foucault (1999) a definição do conceito:

Um conjunto heterogêneo que engloba discursos, instituições, organizações arquitetônicas, decisões regulamentares, leis, medidas administrativas, enunciados científicos, proposições filosóficas, morais, filantrópicas; o dito e o não dito, sendo, portanto, a rede que se pode estabelecer entre esses elementos (FOUCAULT, 1999 apud FERNANDES JÚNIOR; SOUSA, 2014, p.14). 
Assim, na perspectiva foucaultiana, todo exercício de poder instala um dispositivo (CARVALHO; SARGENTINI, 2014). São esses dispositivos os meios pelos quais se materializam e propagam as relações de poder em nossa sociedade, "algo que se exerce, se efetua, e funciona discursivamente" (FERNANDES JÚNIOR; SOUSA, 2014, p.14). Dessa forma, podemos compreender que essas relações se estabelecem como práticas sociais atravessadas pelos discursos produzidos e retomados em nosso cotidiano. A esse respeito, observa Foucault (2008) que:

O dispositivo, portanto, está sempre inscrito em um jogo de poder, estando sempre, no entanto, ligado a uma ou a configurações de saber que dele nascem, mas que igualmente o condicionam. É isto, o dispositivo: estratégias de relações de força sustentando tipos de saber e sendo sustentadas por eles (FOUCAULT, 2008, p.246).

Na biografia de Menchú, a língua espanhola se torna um dispositivo que aciona relações de poder, originadas no processo de colonização da Guatemala pela Espanha. Essas relações estabelecem a diferença entre aquele que é acolhido pela sociedade - o falante de castelhano, a língua imposta como oficial - e aquele que é excluído - o não falante dessa língua. Para (a)firmar-se como sujeito, ou seja, deixar o espaço de exclusão a que estava agrilhoada devido ao desconhecimento do espanhol, a personagem 
busca apropriar-se do dispositivo de poder que lhe pode garantir a inclusão nessa sociedade - a língua do colonizador, alteada ao posto de oficial.

\section{A língua espanhola como dispositivo de exclusão social em Me llamo Rigoberta Menchú y así me nació la conciencia}

Em busca de compreender, na narrativa de Rigoberta Menchú sobre aprender o castelhano, a constituição da língua como dispositivo de exclusão social, analisamos excertos de sua biografia, selecionados em virtude deste objetivo da investigação.

No primeiro excerto, podemos observar que, desde muito cedo, Rigoberta almejava frequentar uma escola. Entretanto, a exclusão socioeconômica a que os indígenas guatemaltecos estavam submetidos impedia a então jovem de alcançar seu anseio.

Yo deseaba un día poder leer o escribir o hablar el castellano. Eso le decía a mi papá, yo quiero aprender a leer. Tal vez cuando lee, sea diferente. Entonces mi papá me decía, ¿quién te va a enseñar? Tienes que aprenderlo por tus medios, porque yo no los tengo. No conozco colegios, tampoco te podría dar dinero para un colegio (BURGOS, 2011, p.115). 
As relações estabelecidas neste excerto indiciam o processo de exclusão indígena. Sem acesso às escolas, devido à situação socioeconômica, e, portanto, postos à margem do conhecimento da língua oficial do país, os indígenas se mantêm excluídos das instâncias da sociedade guatemalteca, em suas montanhas, com terras impróprias para o plantio, sem possibilidade de auxílio governamental ou de educação formal/oficial.

Assim, sem condições econômicas para pagar uma escola, aos treze anos, Menchú decide trabalhar em uma casa de família, pois acreditava ser essa a melhor opção para aprender espanhol, além de também ajudar financeiramente sua família. Contudo, o acesso à língua não lhe garante autoridade sobre a mesma, que se mantém como dispositivo de exclusão. No excerto que segue, por não conhecer as regras de formalidade dos pronomes tú e usted da língua espanhola, Menchú vivencia, uma vez mais, relações de exclusão propiciadas por meio da língua:

No teníamos que le decir una palabra, por ejemplo, de tú, sino que le teníamos que decir usted, porque eran respetados. Entonces, una vez, que a mí me costaba el castellano y apenas empezaba a hablar algunas palabras, yo quizá le dije tú a la señora. Casi me pega. Y me dijo: "Tú será tu madre. Tienes que respetarme tal como soy" (BURGOS, 2011, p. 123, grifos do autor). 
Observemos, na narrativa de Menchú, a perpetuação, herdada do período colonial imposto à Guatemala, da relação de superioridade da señora - falante de espanhol - frente à posição de inferioridade de Menchú como não falante da língua. Mais uma vez, o castelhano é tomado como dispositivo de exclusão: por não estar provida do conhecimento das regras normativas de tratamento formal e informal que regem a língua espanhola, por si só uma evidência da demarcação exclusiva que constitui a língua enquanto herança colonial, o uso "equivocado" dos pronomes pessoais tú e usted por Menchú evidencia a posição que cada personagem ocupa, respectivamente - falante de espanhol/não falante de espanhol, porquanto superior/ inferior, não indígena/indígena, incluído/excluído.

A língua espanhola como dispositivo de exclusão se torna uma vez mais central na passagem da biografia de Menchú em que seu pai é preso pelo governo sob a alegação de que perturbava a soberania do país. Para libertá-lo, a família busca um intérprete para intermediar a negociação com um advogado ladino, falante de castelhano, como pode ser observado no excerto que segue:

Como no hablábamos el castellano, entonces teníamos que buscar un intermediario que tradujera las declaraciones de mi madre. El abogado era un ladino y no entendía la lengua de nosotros. Teníamos que buscar un intermediario para que tradujera. Inmediatamente los terratenientes pagaron al intérprete para que no dijera que nosotros decíamos. 
El intérprete se vendió a los terratenientes y no decía lo que nosotros decíamos sino que decía otras cosas en lugar de la declaración nuestra.

$[\ldots]$

Lo más penoso para nosotros fue que no podíamos hablar. $Y$ yo en ese tiempo decía, tengo que proponerme aprender el castellano. Que no necesitemos intermediários (BURGOS, 2011, p.136 - 137).

No excerto, a prisão do pai reitera a urgência, diagnosticada por Menchú, de aprender a língua oficial do país, empregada pelas autoridades. Diante da necessidade da contratação do intérprete, esse fator remete à marginalidade tanto da própria personagem quanto de sua família, sempre marcante nas relações de Rigoberta com a sociedade guatemalteca. Em meio ao infortúnio da prisão do pai, o não conhecimento da língua a expõe a mais uma situação de exploração: subornado, o intérprete recebe a quantia que lhe é devida pela família de Menchú, mas traduz a verdade conveniente para os terratenientes - daí a insistência, nesta análise, do espanhol como um dispositivo de exclusão.

Como constata a personagem um pouco mais à frente, "la necesidad me obliga a aprender el castellano" (BURGOS, 2011, p.188). De fato, desde o princípio de sua narrativa, Menchú relata inúmeras situações em que não falar a língua oficial de seu país a exclui socialmente. Os excertos analisados são apenas alguns dos 
muitos, narrados em sua biografia, em que o não conhecimento de espanhol colocou a personagem, sua família e sua comunidade em situações de segregação. Foram esses acontecimentos que despertaram sua consciência para a necessidade de aprender a língua. Dessa forma, a história relatada por Rigoberta se refere não somente às sociedades indígenas guatemaltecas, mas a todas as pessoas subjugadas, segregadas, exploradas e massacradas por discursos coloniais de superioridade e exclusão, que ainda nos dias atuais proclamam as diferenças e asseveram as desigualdades.

\section{Palavras finais - o papel da língua é apenas comunicar?}

Neste capítulo, intentamos analisar, ainda que inicialmente, como, no decorrer da biografia de Rigoberta Menchú, a língua castelhana exerceu a função de dispositivo de exclusão social. Ao relatar sua história de vida, situações de disparidade linguístico-social, a que os indígenas da Guatemala foram submetidos desde a colonização do país pelos espanhóis, resultaram em processos de exclusão e de marginalização que, devido à colonialidade (GROSFOGUEL, 2008), perduram e se projetam em momentos atuais. Os excertos analisados parecem esboçar a dimensão das dissimétricas relações de poder, vivenciadas pela personagem, em virtude do não conhecimento da língua considerada oficial desde o processo de colonização.

Desse modo, a narrativa de Menchú, a nosso ver, apresenta a língua espanhola como um dispositivo que define aqueles que estão dentro e aqueles que estão fora 
da sociedade guatemalteca. Assim, Rigoberta traz a lume problemas que perduram desde a colonização: a exploração de mão de obra indígena e a injustiça social decorrentes da segregação linguística. Por meio de sua biografia, a personagem parece lançar mão de sua consciência da necessidade em aprender o castelhano como dispositivo de resistência, para escancarar os efeitos da exclusão, seja da natureza que for. Essa observação nos conduz à seguinte indagação: seria o papel da língua apenas comunicar, como insistimos em (re)afirmar quando questionados sobre seu ensino, aqui em particular do castelhano ou espanhol/língua espanhola como sinônimos da língua do colonizador de grande parte dessas terras chamadas Novo Continente? Entretanto, talvez este seja assunto para outro momento: o silêncio também funciona como dispositivo de exclusão.

\section{REFERÊNCIAS}

BÖCKLER, C. G. Ri okel nqetamaj pa Iximulev. Cuando se quiebran los silencios. Lo que todos debemos saber de la historia de Guatemala. Cidade da Guatemala: Cholsamaj, 2001.

BÖCKLER, C. G; HERBERT, J. L. Guatemala: una interpretación histórico-social. Cidade da Guatemala: Cholsamaj, 2002.

BURGOS, E. Me llamo Rigoberta Menchú y así me nació la conciencia. 20. reimp. Cidade do México: Siglo XXI, 2011, 
CARVALHO, P.H.V; SARGENTINI, V.M. O. Dispositivo, discurso e produção de subjetividade. Goiânia: EdUFG, 2014.

FERNANDES JÚNIOR, Antonio; SOUSA, K. M. Dispositivos de poder em Foucault: práticas e discursos da atualidade. Goiânia: EdUFG, 2014.

FOUCAULT, Michel. A arqueologia do saber. 7. ed. Trad. Luis Felipe Baeta Neves. Rio de Janeiro: Forense Universitária, 2008.

GROSFOGUEL, R. Para descolonizar os estudos de economia política e os estudos pós-coloniais: transmodernidade, pensamento de fronteira e colonialidade global. Revista Crítica de Ciências Sociais, n.80, p.115-147, 2008.

MOURE, J. L. Castellano, español o argentino? In: ACUÑA, L.; BARALO, M.; MOURE, J. L. Qué español enseñar a un extranjero? Buenos Aires: Tinta Fresca. 2015. p. 9-39. 


\section{PRAGMÁTICA E SOCIOLINGUÍSTICA INTERACIONAL: \\ Contribuições para a formação de professor em línguas materna e estrangeiras}

\section{Daniela Gomes de Araújo Nóbrega}

\section{Considerações iniciais}

Discorrer sobre o que, como e para que determinados comportamentos surgem e se desenvolvem no ambiente de ensino e aprendizagem tem sido a força motriz de inúmeros trabalhos acadêmicos, tanto na grande área de Linguística Aplicada (LA) como na área de Formação de Professor (LORSCHER, 2003; DANTAS, 2007; SANTOS, 2007; SOUZA, 2007; SIME, 2008). Inseridos na área de LA, também encontramos vertentes teóricas como a Pragmática (LEVINSON, 2007; MEY, 2001; TAVARES, 2006) e a Sociolinguística Interacional que, apesar de centrar seus esforços nos estudos da interação face a face em diferentes interações sociais, estas correntes teóricas podem ser de grande valia para descrever e analisar a função das várias linguagens usadas em sala de aula e das 
suas implicações tanto para a prática pedagógica do professor de línguas como para a aprendizagem do aluno.

Neste artigo, portanto, apresento a contribuição dos estudos da Pragmática e da Sociolinguística Interacional para entendermos a dinâmica pedagógica nas aulas de línguas. Para tanto, este trabalho está dividido em duas partes. Na primeira, apresento o objetivo principal da corrente teórica, Pragmática, e discuto como tal teoria pode ser utilizada em pesquisas de sala de aula de línguas. $\mathrm{Na}$ segunda parte, apresento o objetivo da abordagem teórica, Sociolinguística Interacional, e discuto como esta teoria pode ser também usada para fins de estudos desenvolvidos sobre as falas em interação no contexto de ensino e aprendizagem de línguas.

\section{Contribuições da pragmática}

A abordagem pragmática remonta desde o início do século XX com o filósofo Charles Morris (1938) com a teoria da Semiótica (apud LEVINSON, 2007; MEY, 2001; TAVARES, 2006). Dentro do campo da semiótica, Morris delimita a sintaxe, a semântica e a pragmática como os três ramos de investigação dentro dos estudos da língua(gem). Como Morris (1938, apud LEVINSON, 2007, p.2) aponta: “[...] Sintática (ou sintaxe), que é o estudo da relação formal dos signos entre si, a semântica, o estudo das relações dos signos aos quais os signos são aplicáveis (os seus designata) e a pragmática, o estudo da relação dos signos com os intérpretes."

Esta definição inicial de Pragmática até agora tem sido criticada por lingüistas e lingüistas aplicados. Alguns acreditam que Pragmática compreende a Semântica ou 
que a Semântica é parte da Pragmática. No entanto, de acordo com Morris (1938 apud LEVINSON, 2007), todas estas vertentes da língua (sintaxe, semântica e pragmática) estão relacionadas com o estudo dos significados, mas em diferentes perspectivas. Do ponto de vista semântico, a linguagem tem sido estudada no nível da sentença, isto é, o que importa é a descrição e análise puramente linguística sem considerar o contexto de uso e o usuário. Tal visão segue um conceito mais estrutural da linguagem.

Os estudos da Pragmática, por sua vez, procuram se preocupar com o estudo da língua pela perspectiva do usuário ou, como Morris diz na citação, 'intérprete' e que está inserido num determinado contexto social. Para este campo de estudo, a função do usuário e da situação social são elementos necessários para compreendermos como e por que usamos determinadas sentenças, por exemplo, numa dada situação de comunicação.

Um dos estudiosos neste campo de investigação, Levinson (2007) tenta fornecer uma definição mais plausível da Pragmática pontuando sua complexidade, que é devido à comparações de natureza teórica com a finalidade da Semântica, Sociolinguística, Psicolinguística, dentre outras áreas interdisciplinares. A dificuldade em definir a Pragmática é refletida em sua relação entre a estrutura da linguagem e usuário da língua. Isto é, a diferença entre Pragmática e Semântica, por exemplo, repousa sobre os princípios adotados para a análise da linguagem. Enquanto a Semântica tende a seguir uma análise a nível frasal sem considerar o uso da linguagem feito pelos usuários, a Pragmática tem como objetivo fazer uma análise linguística do ponto de vista funcional, seguindo a noção de adequação de acordo com contextos específicos, do 
desempenho do usuário da língua e dos aspectos da estrutura do discurso tais como a deixis, implicaturas, atos de fala e pressuposição. Por tal explicação, a Pragmática tende a ser mais semelhante à Sociolinguística do que a Semântica (LEVINSON, 2007; MEY, 2001) por considerar primordial nas análises o papel do usuário no contexto situacional.

A definição mais adequada da Pragmática, portanto, compreende uma abordagem orientada pelo contexto para o estudo da língua. Tal como indicado por Levinson (2007, p. 27), a “Pragmática é o estudo da capacidade dos usuários da língua para emparelhar frases com os contextos em que seria adequado". Com base nesta concepção, uma conta pragmática do uso da linguagem não só abrange os significados sociais da estrutura lingüística de eventos sociais específicos (GUMPERZ, 2002), também leva em conta todos os fatores contextuais que dizem respeito à posição social e classe social dos usuários, da adequação do nível da linguagem em situações de uso da língua, das relações de poder imbricadas no uso que o falante faz da língua, e de suas contribuições para a (co) construção de um evento comunicativo como um todo (LEVINSON, 2007; MEY, 2001).

Dentro dos estudos da linguagem voltados para a área de educação, as tendências atuais de pesquisa em Línguistica Aplicada têm sido, cada vez mais orientada, para uma perspectiva sociolinguística e mais definida pela competência pragmática. Isto é, abordar os estudos da língua(gem), seguindo este viés, nos permite perceber o uso das língua(gens) nas suas mais variadas formas, enfatizando inúmeras práticas sociais de acordo com o perfil do usuário (ROSE; KASPER, 2001). Dar aulas de língua 
inglesa para crianças, por exemplo, requer do professor uma conduta mais orientada pela ludicidade. Ensinar como usar a língua(gem) em jogos, explicando o porquê de algumas expressões serem necessárias para entender o funcionamento do jogo pode ser trabalhada com professores deste idioma para motivar o interesse dos alunos em estudar Inglês. Tal viés segue uma perspectiva Pragmática do ensino (LEVINSON, 2007; MEY, 2001).

Seguindo o viés da Pragmática, as pesquisas em sala de aula muitas vezes descrevem, observam e discutem como os professores e os alunos costumam se comportar de forma verbal e não verbal para atingir os objetivos de ensino e aprendizagem, e como eles co-constroem conhecimentos relevantes através de seus atos comunicativos, por exemplo, por meio de suas falas. Questões que lidam (1) com o uso dos gestos e sorriso nas falas em interação (OLIVEIRA, 2007; NÓBREGA, 2011), (2) com a percepção dos alunos sobre os gestos dos professores (LORSCHER, 2003), (3) com a função dos elementos não verbais da linguagem em sala de aula (SANTOS, 2007; GREGERSEN, 2007; ACIOLI, 2007; SOUZA, 2007) são alguns dos exemplos de estudos que usam os conceitos e princípios da Pragmática para entender o funcionamento da língua(gem) entre professor e alunos.

No que concerne o uso do sorriso em sala de aula, dois interessantes trabalhos mostram a implicação do sorriso para a aprendizagem da língua. Oliveira (2007), por exemplo, constatou que este elemento pode estabelecer uma proximidade maior entre professor e alunos, mas também pode ser usado num momento de reprimenda, se usado pelo professor. Desta forma, o sorriso do professor acompanhado pelo olhar severo e tom de voz rígido 
pode ser indicativo não verbal para chamar a atenção dos alunos. Por sua vez, Nóbrega (2011) identificou dois tipos de sorriso em momentos distintos na sala de aula, revelando comportamentos também distintos de aprendizagem dos alunos. Quando em grupo com seus colegas, os alunos tendem a usar o sorriso espontâneo propiciando uma maior produção oral. Quando em contato direto com o professor, sobretudo quando estão tirando dúvidas, o sorriso do aluno mais tímido, sendo denominado social, aparece e implica numa diminuição da produção oral.

Sobre o uso dos gestos do professor, Santos (2007) e Gregersen (2007) asseveram que os sinais não verbais na sala de aula tendem a contradizer, complementar, explicar ou monitorar a fala. Quando usada pelo professor, estes sinais tendem a ser usados para esclarecer algo que está sendo dito no momento da aula. Daí porque são, na maioria das vezes, chamados de explicativos. Gumperz (1982) define estes sinais como gestos funcionais uma vez que eles são usados, no contexto de sala de aula, para complementar o objetivo pedagógico iniciado pela fala do professor.

Ainda sobre os gestos, três estudiosos revelaram funções relevantes para o ensino. Para Acioli (2007), Santos (2007) e Souza (2007), os elementos não verbais usados pelo professor tendem a facilitar a aprendizagem dos alunos, levando-os a visualizar melhor a explicação dado pelo professor, por exemplo. Em alguns casos, Acioli (2007) pontua que os movimentos das mãos do professor podem ser usados para controlar a classe, sobretudo quando o professor leciona para alunos que são adolescentes.

$\mathrm{Na}$ Alemanha, por sua vez, Lorscher (2003) observou que a percepção dos alunos sobre os gestos do professor 
tende a ajudar na aprendizagem também. Para os iniciantes, os gestos ajudam na compreensão da explicação do vocabulário, quando o professor dá um feedback positivo e na explicação das atividades a serem feitas em sala. Já para os avançados, os gestos do professor tende a ser menos usado e os alunos se baseiam mais na fala do professor.

Estes estudos, aqui mostrados, revelam que só é possível entendermos o uso dos elementos não verbais - o sorriso, os gestos, por exemplo - quando descrevemos e analisamos tais elementos num determinado ambiente social. O que faz com que entendamos a função social e interativa tanto dos gestos como do sorriso é também a noção pragmática da linguagem. Para compreendermos as implicações destes sinais não verbais para o ensino, faz-se necessário compreendermos quem usa, para quem, em que momento, em que situação e com que objetivo comunicativo, pedagógico e de aprendizagem. Seguindo este viés pragmático da linguagem, os professores de língua começam a entender o porquê de suas práticas pedagógicas, da implicação destas práticas para a aprendizagem dos seus alunos e de como funciona os mecanismos de interação em sala de aula. A seguir, comento sobre as contribuições da Sociolinguística Interacional para os estudos da linguagem e para a formação de professor em Línguas.

\section{Contribuições da sociolinguística interacional}

A Sociolingüística Interacional (SI) é conhecida dentro da área dos estudos linguísticos como uma vertente téorica que discute a organização social do discurso pelo ponto de vista sociológico e linguístico. Linguisticamente, a SI descreve a organização estrutural do discurso falado 
por meio da análise de como o tema/assunto é desenvolvido pelos interlocutores, por exemplo. Do ponto de vista sociológico, esta vertente aborda questões de língua, cultura e sociedade em estudos de interações sociais. Isto é, a SI descreve e analisa como os indivíduos (re)constroem suas identidades sociais através do uso da linguagem em uma variedade de encontros conversacionais (GUMPERZ, 1982; RIBEIRO; GARCEZ, 2002).

Esta teoria tem como procedimento metodológico a pesquisa etnográfica. Com base em observações etnográficas, Blom e Gumperz revelaram que os significados das ações e expressões dos interlocutores, em interações conversacionais, não estão relacionados apenas às palavras pronunciadas pelos interlocutores. Ao descrever o comportamento verbal de uma comunidade norueguesa, eles constataram que é o evento social que determina se o dialeto ou a linguagem padrão deve ser escolhido em conversas. Os sinais de prosódia, pronúncia, compartilhamento de conhecimentos, a organização sequencial dos diálogos, o sistema da tomada de turnos e a sinalização adequada de pistas de contextualização (GUMPERZ, 1982) são tidos como alguns dos elementos sociolinguísticos utilizados para indicar diferentes significados sociais e culturais em eventos interacionais diversos.

Para a SI, os interlocutores (ou usuários) são considerados como co-construtores ativos de encontros sociais (MARCUSCHI, 1991; TAVARES, 2007). Segundo esses autores, os indivíduos estão constantemente em um jogo cooperativo para construir sentidos em qualquer encontro conversacional (WARDHAUGH, 1985; MARCUSCHI, 1991; BLOM; GUMPERZ, 2002). A linguagem utilizada, os significados socioculturais imbricados em suas falas, 
as expectativas, valores e percepções, crenças, o conhecimentocomunicativo, pragmáticoea informaçãocontextual compartilhada por estes interlocutores são considerados como fatores extralinguísticos que podem modificar o contexto do encontro conversacional (GUMPERZ, 1982; WARDHAUGH, 1985; KRAMSCH, 2001; TAVARES, 2006, 2007). Contudo, os próprios usuários também podem usar signos linguísticos e não linguísticos durante estes encontros com a finalidade de modificar o curso de uma conversa. Tanto o contexto como os usuários são considerados fatores condicionantes para modificar o rumo que uma determinada conversa toma.

Situada no cruzamento das áreas de Linguística, Antropologia e Sociologia, a SI emergiu com os trabalhos de Gumperz (GUMPERZ, 1982; GORDON, 2010). Com ênfase na investigação sobre a diversidade linguística e cultural presentes em conversas do cotidiano, Gumperz (1982), o precursor desta vertente teórica, investigou os problemas de comunicação intercultural, para compreender como os indivíduos constroem e mantêm relacionamentos, exercem relações de poder, projetam e negociam identidades sociais.

Pelo viés linguístico, a SI analisa os aspectos estruturais e funcionais da linguagem inseridas num conceito mais amplo de interação social. O estudo mais relevante no âmbito da abordagem linguística foi da análise sobre as pistas de contextualização (GUMPERZ, 1982; LEVINSON, 2007). O objetivo deste autor foi investigar como interlocutores sinalizam, constroem e interpretam significados em interações sociais. Estes mecanismos de sinalização foram definidos por Gumperz como pistas de contextualização. Usando suas próprias palavras, a pista de 
contextualização "[...] é qualquer característica de forma linguística que contribue para a sinalização de pressuposições contextuais" ${ }^{1}$ (GUMPERZ, 1982, p.131). De acordo com este autor, é através destes mecanismos de sinalização, que podem ser de natureza prosódica, linguística ou paralingüística, que os interlocutores são capazes de reconhecer e interpretar uma mensagem em desenvolvimento numa interação face a face.

Seguindo uma abordagem antropológica, a SI objetiva desvendar questões culturais entre os interlocutores na análise das conversas do cotidiano. Neste sentido, a SI destaca a intersecção da língua e da cultura. Esta abordagem, portanto, discute que significados culturais os interlocutores atribuem às suas ações e palavras, enquanto estão envolvidos em encontros face-a-face. Um dos aspectos que merece atenção nesta perspectiva é o estudo da comunicação e conflito intercultural, que muitas vezes são baseados em diferenças culturais (GUMPERZ, 1982; GORDON, 2010). Estas pesquisas mostram que os desentendimentos normalmente ocorrem porque os participantes tendem a não compartilhar conhecimentos tanto de uso palavras e expressões típicas de suas culturas como de atitudes, também de natureza cultural. Este tipo de choque cultural, presente no uso da linguagem como no comportamento como um todo, tende a provocar desentendimentos e conflitos de cunho intercultural nas conversas.

Através de uma abordagem sociológica, a SI destaca a relação entre linguagem e sociedade, ou seja, investiga como as pessoas usam a linguagem para atingir os

1 Texto original: "[...] is any feature of linguistic form that contributes to the signaling of contextual pressupositions"(p.131). 
seus objetivos sociais, bem como para criar e negociar suas identidades sociais (GUMPERZ, 1982; GORDON, 2010). Sua principal contribuição teórica foi o estudo de Garfinkel. Segundo este autor, os interlocutores constroem suas realidades sociais e identidades através das suas declarações e ações em conversas diárias. O conhecimento sócio-cultural dos indivíduos - que vem de sua coleção de experiências culturais - tende a moldar suas identidades e valores sociais, implicando, desta forma, no comportamento verbal em interações face a face. Em suma, a SI procura discutir as implicações inferenciais em conversas, seja dos assuntos privados ou públicos, a partir da investigação da forma dos interlocutores co-construir e negociar suas posições sociais, papeis e identidades em encontros de conversação.

Por meio de metodologias de pesquisa de natureza qualitativa e cunho etnográfico, a SI descreve e analisa conversas informais e formais, ocorrendo prioritariamente em ambientes naturais. Baseia-se, basicamente, sobre o que acontece no exato momento de uma linguagem particular na situação de uso. Por esta razão, o seu método de análise tenta desvendar os processos inferenciais de conversas por meio de uma série de instrumentos: de áudio ou dados gravados em vídeo, entrevistas, aplicações do questionário e transcrições linguísticas de conversas gravadas.

Para ilustrar alguns estudos usando a SI na interação em sala de aula, podemos apontar a pesquisa de Nóbrega (2011) sobre o uso de marcadores discursivos de uma professora e suas implicações para a produção oral dos alunos em aulas de língua inglesa num curso de Letras- Inglês de uma instituição pública. De acordo com a SI, o uso dos 
elementos verbais, neste caso o dos marcadores conversacionais, e não verbais em qualquer evento interacional é social e culturalmente marcado. Também conhecidos como conectores pragmáticos e organizadores interacionais (URBANO, 2006), os marcadores conversacionais/ discursivos são sinais produzidos pelos interlocutores para relacionar as unidades comunicativas e orientar os sistemas de turnos durante a conversação. São esses sinais responsáveis pela organização da coerência nas conversas. De acordo com Marcuschi (1991) e Schiffrin (1987), os marcadores discursivos sinalizam às atitudes e intenções comunicativas dos interlocutores. De acordo com os resultados da pesquisa de Nóbrega (2011), os marcadores conversacionais da professora geralmente se posicionam antes das perguntas que ela mesma faz, nos levando a concluir que tal comportamento verbal orientava sobre o que e como os seus interlocutores (os alunos) deviam falar e se comportar nas atividades em sala de aula.

Conforme mostrado por Sinclair \& Coulthard (1975) e discutido por Marcuschi (1991), os resultados da pesquisa de Nóbrega (2011) também apontam que é o professor que ainda assume a responsabilidade de comandar os turnos conversacionais, sobretudo nas sequências interacionais de iniciação e avaliação. Como consequência dessa estratégia pedagógica assumida pela professora, os alunos intermediários tendem a desenvolver uma produção oral mais referencial do que expressiva. Quer dizer, suas respostas estão sempre de acordo com as perguntas feitas pela professora cujas respostas já são de conhecimento dela. As respostas expressivas, por sua vez, não são de conhecimento da professora e correspondem às opiniões dos alunos sobre o que está sendo debatido em sala de aula. 
Através de pesquisas como a apresentada acima, é que podemos inferir que condutas verbais do professor em sala de aula podem repercutir negativamente em relação à produção oral dos alunos, por exemplo. Tal conduta em sala nos faz refletir que a maioria dos alunos ainda se prende na concepção de que é o professor quem determina o que e como deve ser feito na sala, e aos alunos cabe ainda à função de responder ao que é pedido em sala de aula.

Observando a sala de aula, mais particularmente as atitudes verbais do professor conforme apresentado no trabalho de Nóbrega (2011), pelo viés da SI, os professores de línguas podem refletir de forma crítica sobre suas condutas e de suas implicações para a participação oral dos alunos em sala. A SI pode, portanto, orientar os professores para assumir uma postura mais crítica sobre o seu fazer docente, os fazendo questionar e refletir sobre o comportamento verbal e também o não verbal nas interações em sala de aula.

\section{Considerações finais}

Acreditamos que estes estudos, neste capítulo apresentados, podem contribuir para a Formação de Professores de Línguas uma vez que tais correntes téoricas, i.e. a Pragmática e a Sociolinguística Interacional, podem contribuir para a tomada de consciência crítica dos professores sobre o seu fazer docente.

Seguindo os princípios da Pragmática, os professores de línguas podem vir a refletir sobre suas práticas pedagógicas através de suas falas e de seu comportamento não verbal, por exemplo. Atentando-se sobre como e para que 
usamos uma variedade de linguagens no ambiente de sala de aula, no caso a linguagem verbal (a fala) e a não verbal (gestos, expressões faciais), os professores podem mudar suas condutas e, consequentemente, seu modo de lecionar procurando ser mais cuidadosos sobre suas condutas e suas respectivas implicações tanto para o ensino como para a aprendizagem dos alunos. A título de exemplo, quando um(a) professor(a) tende a usar as mãos enquanto fala, ele/ela pode tornar a fala mais clara e objetiva para os alunos pelo fato de ser, o movimento das mãos, um elemento não verbal que complementa a fala.

Já de acordo com o viés da Sociolinguística Interacional, questões que lidam com a identidade social e cultural, tanto do(a) professor(a) como do(a) aluno(a), são levadas em consideração. O que professor(a) e/ ou aluno(a)s faz na sala de aula pode representar a cultura e os valores sociais que eles/elas adotam em suas vidas. Isto, por sua vez, está imbricado na conduta em sala de aula e em vários momentos de ensino e aprendizagem.

Compreender as várias formas de ensinar e aprender um idioma (tanto da língua materna como estrangeira) não se limita apenas à questões de gramática mas, primordialmente, às inúmeras formas de lidar com as linguagens como um todo e de como podemos adequálas no contexto escolar, contexto este onde estão inseridos pessoas de culturas, valores e crenças diferenciadas. Por meio das discussões teóricas, aqui expostas, podemos concluir que tanto a Pragmática como a Sociolinguísitca Interacional podem contribuir teórica e pedagogicamente para que nós, professores, possamos colocar em prática um olhar mais crítico sobre nossas condutas em sala de aula. 


\section{REFERÊNCIAS}

ACIOLI, H. K. B. 2007. A Interação existente entre os elementos não-verbais e verbais no discurso de sala de aula. In: SANTOS, Maria Francisca Oliveira (org.), Os elementos verbais e não verbais no discurso de sala de aula. Maceió: EDUFAL, p.87-96.

DANTAS, L. M. 2007. Nonverbal Language in EFL classroom interaction. Maceió, AL. Dissertação de Mestrado. Universidade Federal de Alagoas. 74 p.

GORDON, C. Gumperz and interactional sociolinguistics. In: WODAC, R.; JOHNSTONE, B.; KERSWILL, P. E. (Ed.). The sage handbook of sociolinguistics. Thousand Oaks: SAGE Publications, 2010.

GREGERSEN, T. S. Language learning beyond words: Incorporating body language into classroom activities. In: Reflections on English Language Teaching, v.6, n.1, p.5164. 2007. Disponível em: www.nus.edu.sg/celc/publications/reltVol61.htm Acesso em: 04 jan.10.

GUMPERZ, J. J. Discourse Strategies. Cambridge: Cambridge University Press, 1982. (Studies in Interactional Sociolinguistics, 1)

KRAMSCH, C. Contexts of speech and social interaction. In: KRAMSCH, C. (Ed.). Context of culture in language teaching. Oxford: Oxford University Press, 2001. p. 34-69.

LEVINSON, S. C. Pragmática. Tradução Luís Carlos Borges, Aníbal Mari; revisão da tradução Aníbal Mari; revisão técnica Rodolfo llari. São Paulo: Martins Fontes, 2007. 
LORSCHER, W. Nonverbal aspects of Teacher-pupil communication in the Foreign language classroom. Web Proceedings, July 2003. Disponível em: www.ec.hku.hk/ $\mathrm{kd} 2$ proc/proceedings/fullpaper/.../LorscherWolfgang. pdf. Acesso em: 05 dez. 09.

MARCUSCHI, L. A. 1991. Análise da conversação. 2. ed., São Paulo: Ática, 1991. 89 p.

MEY, J. L. Pragmatics: an introduction. 2 ed. Malden: Blackwell, 2001.

NÓBREGA, D. G. A fala do professor e produção oral dos alunos. In: Calidoscópio, v.9, n.1, p.50-55, jan/abr .2011.

OLIVEIRA, C. L. A relevância dos efeitos faciais na conversação face a face no ambiente de sala de aula. In: SANTOS, Maria Francisca Oliveira (org.). Os elementos verbais e não verbais no discurso de sala de aula. Maceió: EDUFAL, 2007. p.45-68.

RIBEIRO, T. R.; GARCEZ, P. M. (Org.). Sociolinguística interacional. 2. ed. São Paulo: Loyola, 2002. (Coleção Humanística. Série 07598). ISBN: 9788515025169.

ROSE, K. R.; KASPER, G. (Ed.). Pragmatics in language teaching. Cambridge: Cambridge University Press, 2001. p.1-10.

SANTOS, M. F. O. Os elementos verbais e não verbais no discurso de sala de aula. In: SANTOS, Maria Francisca Oliveira (org.), Os elementos verbais e não-verbais no discurso de sala de aula. Maceió: EDUFAL, 2007. p.17-44. 
SOUZA, D. P. A Intersecção entre a fala e os gestos no comportamento do professor em sala de aula. In: SANTOS, Maria Francisca Oliveira (org.), Os elementos verbais e não verbais no discurso de sala de aula. Maceió: EDUFAL, 2007, p. 45-68.

TAVARES, R. R. A interação verbal no contexto pedagógico à luz da micro-análise etnográfica da interação. In: LEFFA, V. (Org.). Pesquisa em lingüística aplicada: temas e métodos. Pelotas: Educat, 2006.

OLIVEIRA, C. L. A relevância dos efeitos faciais na conversação face a face no ambiente de sala de aula. SANTOS, Maria Francisca Oliveira (org.), In: Os elementos verbais e não verbais no discurso de sala de aula. Maceió: EDUFAL, 2007. p.45-68.

WARDHAUGH, R. Ethnography and Ethnomethodology. In: An introduction to Sociolinguistics. Third edition. Blackwell publishers: USA, 1998. p.237-254. 


\title{
OS PROCESSOS E CRITÉRIOS DE ESCOLHA DE LIVROS DIDÁTICOS DE PORTUGUÊS: o que dizem os professores?
}

\author{
Taíza Ferreira de Souza Cavalcanti (UFPE) \\ Alexsandro da Silva (UFPE)
}

\begin{abstract}
"Quando a gente aprende a ler, as letras, nos livros, são grandes. Nas cartilhas - pelo menos nas cartilhas do meu tempo - as letras eram enormes" (VERÍSSIMO, 2008, p. 111).
\end{abstract}

Ao iniciar nossas considerações acerca do processo de escolha do livro didático de português vivenciado por professores de língua portuguesa atuantes no Ensino Fundamental, remetemo-nos ao fragmento da crônica de Luís Fernando Veríssimo (1998), porque, quando ele faz a menção às cartilhas do seu tempo, provoca-nos a refletir sobre os livros escolares de uma determinada época, na qual a escola não era acessível a todos e não existiam grandes editoras, nem políticas públicas para avaliação e distribuição de livros didáticos (LDs). 
Diferentemente dessa época, hoje podemos olhar para uma escola que, apesar de apresentar limitações políticas, estruturais e pedagógicas, expandiu o seu acesso aos estudantes de classes populares, assim como ampliou o acervo de materiais impressos nela disponíveis, entre os quais se incluem os livros didáticos. Esse recurso, outrora notadamente escasso nas salas de aula, permitiu contemplar a necessidade de alunos e professores no que se refere à existência de um material de apoio ao ensino e à aprendizagem.

Nesse contexto, com a criação do Programa Nacional do Livro Didático (PNLD), as questões relacionadas à escolha e ao uso de livros didáticos nas escolas públicas brasileiras passaram a receber novos encaminhamentos políticos e pedagógicos. Hoje, os professores têm mais autonomia para escolher o livro didático e os alunos da educação básica passaram a receber livros da maior parte das disciplinas das áreas do currículo escolar.

O PNLD, tendo em vista disponibilizar livros didáticos de melhor qualidade, se tornou um instrumento de suma importância para a melhoria do LDP ao definir critérios avaliativos que têm contribuído para a incorporação de novas orientações teóricas e metodológicas ao LDP. Desse modo, é necessário que esse recurso atenda, além de critérios gerais, critérios específicos da área, correspondentes a cada eixo do ensino de língua portuguesa, os quais se baseiam, em muitos aspectos, nas discussões teóricas fomentadas, principalmente, a partir da década de 80 do século passado. Em outras palavras, é critério de avaliação dos livros didáticos a adequação das propostas dos eixos de leitura, produção de textos escritos, oralidade e análise linguística. 
Nessa direção, concordamos com Rangel (2005), quando observa que,

O PNLD, especificamente a partir da avaliação, estabeleceu perspectivas teóricas e metodológicas bastantes definidas para o LDP, perspectivas estas que se tornaram possíveis graças a uma movimentação no campo de reflexão sobre o ensino da língua materna (RANGEL, 2005, p.14).

Sendo assim, a submissão dos livros a um processo de avaliação criterioso e sistemático passou a requerer que editoras buscassem adequar as suas produções aos padrões estabelecidos pelo Ministério da Educação (MEC) $\mathrm{e}$, consequentemente, produzissem livros que atendessem em certa medida às perspectivas teóricas mais atuais no campo do ensino de língua.

Atualmente, embora o professor disponha de variados recursos pedagógicos para subsidiar as suas práticas de ensino, o livro didático continua sendo um dos materiais mais frequentemente utilizados em sala de aula, provavelmente porque a coletânea textual, as propostas de atividades, as sugestões de projetos de didáticos e os demais recursos que o constituem podem facilitar o trabalho docente. Segundo Batista e Val (2004, p.17), “o livro didático está presente cotidianamente na sala de aula e constitui um dos elementos básicos da organização do trabalho docente".

Desse modo, reconhecendo a importância que o livro didático tem no cenário da educação brasileira, assim 
como o surgimento e desenvolvimento do PNLD, que avalia e distribui esses livros, o presente estudo buscou investigar como ocorre o processo de escolha do LDP e quais os critérios considerados pelos docentes ao realizarem suas escolhas.

\section{O PNLD e o processo de escolha dos livros didáticos}

A partir dos anos de 1970, o quantitativo de alunos nas escolas públicas brasileiras foi se expandindo, o que fez emergir a necessidade de novos direcionamentos políticos e pedagógicos para que a escola pudesse atendê-los. Tais encaminhamentos começaram a acontecer de forma mais efetiva com a chegada dos anos 1980, época na qual o governo iniciou a disponibilização de maiores investimentos financeiros para o campo educacional e que foi marcada pela ruptura com paradigmas pedagógicos até então cristalizados na história da educação.

Nesse contexto de mudanças, o Governo Federal, através do decreto Lei $n^{\circ} 91.542$ de 19 de agosto de 1985, estabeleceu, entre outras determinações, que os livros didáticos seriam escolhidos pelos professores, conforme a sua área de atuação, e deveriam ser utilizados por três anos até o momento da nova escolha. Esse decreto também estabeleceu o fim da participação financeira dos Estados no processo de aquisição e distribuição dos livros ${ }^{1}$.

Essas medidas criaram o Programa Nacional do Livro didático (PNLD), em parceria com o Fundo Nacional de Educação (FNDE), órgão federal responsável pela

1 Informações disponíveis no site do FNDE. 
administração de recursos que viabilizam a aquisição, avaliação e distribuição dos livros didáticos. Ao discorrer sobre a implementação desse Programa, Bagno (2007, p.18) argumenta que,

Desde sua primeira edição, o PNLD vem provocando uma transformação radical na cultura do livro didático em nosso país. Vencida a resistência inicial das grandes empresas editoriais, e também a de muitos autores - que se recusavam a incorporar naquelas obras uma nova filosofia de ensino-aprendizagem que substituísse a velha prática de transmissão mecânica de conteúdos tradicionais, sem apelo à participação ativa-criativa do aprendiz (e do docente) -, é possível dizer que o material didático hoje no mercado brasileiro apresenta inegáveis qualidades, sobretudo em comparação com o que se produzia antes (BAGNO, 2007, p.18).

Inicialmente, quando foi criado em 1985, o PNLD não apresentava a organização e atribuições que tem hoje, visto que esses aspectos foram modificados e ampliados a partir de 1996 (BATISTA; COSTA VAL, 2004). Devido às atribuições que caracterizam esse Programa, Costa Val (2009, p.13) define o PNLD como "parte das políticas públicas de educação desenvolvidas pelo MEC. Seu objetivo é a distribuição gratuita de livros didáticos para 
todos os alunos das escolas públicas do ensino fundamental (EF) no Brasil".

Essa política de avaliação e distribuição de livros didáticos não atingiu imediatamente todos os níveis de ensino, pois foi sendo gradativamente implantada, de modo que, inicialmente, atendia apenas aos estudantes do ensino fundamental. A partir de 2006, começou a disponibilizar livros didáticos para os estudantes do ensino médio, atendimento que se iniciou pelos livros de português e matemática e, gradualmente, foi se ampliando até abranger todas as disciplinas.

Desde a implantação do PNLD, muitas modificações relacionadas à presença dos LDs na escola aconteceram. Tais mudanças envolveram mercado editorial, investimento financeiro, adequação dos livros face aos novos paradigmas científicos e metodológicos, entre outras modificações, que, de forma gradativa, exigiram desse Programa uma organização sistemática e criteriosa de suas ações (BATISTA, 2004; BATISTA; COSTA VAL, 2004; COSTA VAL, 2009; BATISTA; ROJO, 2006).

Para tal organização, o PNLD tem-se desenvolvido por meio do cumprimento de algumas etapas, iniciadas pela adesão das redes ao Programa e contemplando ainda a inscrição das editoras, a avaliação das coleções, o processo de escolha realizada pelos professores e, por fim, o recebimento dos exemplares.

Ao analisarmos tais etapas, percebemos que o PNLD é realizado por meio de ações que buscam assegurar o direito de alunos e professores de escolas públicas a terem acesso a livros didáticos de melhor qualidade. Nessa direção, faz-se necessário que esses recursos constituam subsídios que estejam a serviço da prática docente, de forma 
que, ao abordarem os conteúdos, apresentem propostas de atividades diversificadas que ampliem o desenvolvimento dos processos de ensino e aprendizagem. Como aponta Pavão (2006, p.4), "o livro deve contribuir para que o professor organize sua prática e fornecer questões de aprofundamento das concepções pedagógicas desenvolvidas na escola".

Entretanto, apesar das ações desenvolvidas pelo PNLD, o processo de escolha do LD nem sempre tem acontecido da maneira prevista pelo Programa. Batista (2004), em pesquisa de caráter exploratório realizada com professores que participaram do processo de escolha no PNLD/2001, constatou que os docentes demonstraram possuir informações limitadas sobre o processo de avaliação dos livros didáticos. Nessa mesma direção, a investigação realizada por Costa Val (2002) apontou que os professores preferiam consultar os exemplares das coleções didáticas em vez do Guia. Quanto a esse material, os professores participantes desse estudo declararam que ele não havia chegado à escola a tempo suficiente para ser consultado, além de a quantidade de exemplares ser insuficiente para atender a todos os docentes. Em alguns casos, o Guia ficava sob o controle da equipe pedagógica da escola, o que também dificultava o contato dos professores com esse material e, consequentemente, com a avaliação nele presente sobre os livros.

No que alude ao momento da escolha do livro, Costa Val (2002) observou que cada caso apresentava suas peculiaridades, mas que, geralmente, o momento da escolha era organizado pelas secretarias municipais de educação, que convidava os professores para se reunirem por área de atuação. Nessa reunião, os docentes negociavam suas 
propostas de escolha, indicando os livros que preferiam e, em outros casos, eram realizadas plenárias com votações sobre qual livro deveria ser escolhido.

Nessa mesma linha de investigação, a pesquisa desenvolvida por Castanheira e Evangelista (2002), que teve como objetivo perceber padrões recorrentes ou diferenciados de processos de escolha dos LDs em escolas públicas do país, constatou situações diversificadas no que se refere à escolha, ao recebimento e ao uso dos livros de língua portuguesa e alfabetização. Uma das tendências sinalizadas na pesquisa aponta que, provavelmente, havia uma relação entre o processo de escolha e a organização escolar, uma vez que as escolas que demostraram maior organização pedagógica fizeram opção de escolha por livros mais qualificados.

A segunda tendência sinalizada na pesquisa apontou que, nos casos das escolas que se organizavam de forma híbrida (ciclos e séries), os padrões de escolha foram diferenciados, pois foi observado que, nas fases iniciais do ciclo, os professores demonstravam um padrão de preferência por livros que apresentam melhores recomendações, enquanto que nas séries finais do segmento observou-se preferência por livros menos qualificados. Ainda foi observado que, em alguns casos, os professores não utilizaram os livros recebidos, visto que, embora esses fossem bem avaliados, não correspondiam à escolha realizada, o que fazia com que utilizassem outros manuais.

Diante do exposto, reconhecendo que as práticas de ensino são muitas vezes subsidiadas pelo uso do livro didático, decidimos investigar como ocorreu o processo de escolha do LDP numa escola estadual de Pernambuco, 
situada na cidade de Arcoverde, e quais os critérios os docentes de língua portuguesa utilizaram para escolher as coleções didáticas.

\section{O estudo sobre os processos e critérios de escolha de livros didáticos: campo, participante e procedimentos}

Compreendendo que uma pesquisa nasce da necessidade de um conhecimento novo ou mais profundo sobre de uma questão que nos inquieta, realizamos esse estudo objetivando investigar como ocorreu o processo de escolha do LDP em uma escola da rede estadual de ensino de Pernambuco, situada no município de Arcoverde-PE, e quais foram os critérios considerados pelos docentes ao realizarem suas escolhas.

Para delimitarmos nosso campo de estudo, fizemos um estudo exploratório nas escolas pertencentes à Secretaria Estadual de Educação de Pernambuco, localizadas no município de Arcoverde-PE, com o objetivo de conhecer quais foram as coleções ou os livros didáticos de língua portuguesa adotadas pelas escolas e/ou professores no âmbito do PNLD/2014. Ao visitarmos essas instituições de ensino, constatamos que 3 (três) das 10 (dez) escolas visitadas fizeram a opção pela coleção "Projeto Teláris: Português", da Editora Ática, 2 (duas) escolheram a "Para Viver Juntos: Português", da Editora SM e outras 2 (duas) escolheram a coleção "Jornadas.port - língua portuguesa", da Editora Saraiva". As demais escolheram, cada uma, um livro diferente.

Mobilizados pelo objetivo mencionado anteriormente, e diante dos dados obtidos durante o estudo 
exploratório, realizamos uma sessão de grupo focal (GF), que nos permitiu ter acesso, por meio dos depoimentos dos docentes, a como se deu o processo de escolha do LDP e quais critérios de escolha foram utilizados pelos professores. Escolhemos essa técnica por compreendermos que ela possibilita ao pesquisador conhecer o que cada participante de um determinado grupo social pensa a respeito de um assunto comum, ou seja, conhecer o que um grupo pesquisado pensa sobre um tema que faz parte das suas práticas cotidianas (GATTI, 2012).

Para organização e realização da sessão do GF, visitamos as escolas nas quais as coleções de LDP adotadas na rede estadual de ensino de Arcoverde-PE foram as mais escolhidas, visando a convidar os professores de português a participarem da pesquisa, que seria realizada em cada escola, conforme horário a ser combinado com os professores. No entanto, devido a razões operacionais e/ ou de receptividade, não foi possível efetivar o estudo em todas elas. Por isso, participaram da referida sessão uma professora e dois professores de língua portuguesa de uma das escolas. No quadro a seguir, apresentamos o perfil desses professores. 
Quadro 1- Dados pessoais e profissionais dos(as) professores (as)

\begin{tabular}{|c|c|c|c|}
\hline $\begin{array}{l}\text { Dados dos } \\
\text { professores }\end{array}$ & Alice & Mário & Felipe \\
\hline Idade & 41 anos & 26 & 27 \\
\hline $\begin{array}{l}\text { Graduação } \\
\text { (curso, rede } \\
\text { e ano de } \\
\text { conclusão) }\end{array}$ & $\begin{array}{c}\text { Letras } \\
\text { Instituição } \\
\text { Pública } \\
1997\end{array}$ & $\begin{array}{l}\text { Letras } \\
\text { Instituição } \\
\text { Pública } \\
2010\end{array}$ & $\begin{array}{l}\text { Letras } \\
\text { Instituição } \\
\text { Pública } \\
2011\end{array}$ \\
\hline $\begin{array}{l}\text { Pós- } \\
\text { graduação } \\
\text { (latu sensu, } \\
\text { stricto sensu) }\end{array}$ & $\begin{array}{l}\text { Especialização } \\
\text { em Metodologia } \\
\text { do Ensino } \\
\text { de Língua } \\
\text { Portuguesa - } \\
\text { 2006/2007 }\end{array}$ & $\begin{array}{c}\text { Especialização } \\
\text { em Metodologia } \\
\text { do Ensino } \\
\text { de Língua } \\
\text { Portuguesa - } \\
\text { 2011/2012 }\end{array}$ & $\begin{array}{c}\text { Especialização } \\
\text { em Metodologia } \\
\text { do Ensino } \\
\text { de Língua } \\
\text { Portuguesa } \\
\text { 2012/2013 }\end{array}$ \\
\hline $\begin{array}{l}\text { Quantidade } \\
\text { de anos de } \\
\text { experiência } \\
\text { como } \\
\text { docente }\end{array}$ & $\begin{array}{c}9 \text { anos } \\
\text { (atua desde } \\
2006)\end{array}$ & $\begin{array}{c}5 \text { anos }^{2} \\
\text { (contratado } \\
\text { desde 2012) }\end{array}$ & $\begin{array}{c}2 \text { anos } \\
\text { (contratado } \\
\text { desde 2012) }\end{array}$ \\
\hline $\begin{array}{l}\text { Atuação em } \\
\text { outra escola } \\
\text { ou rede de } \\
\text { ensino }\end{array}$ & Sim & Não & Sim \\
\hline $\begin{array}{l}\text { Situação de } \\
\text { trabalho na } \\
\text { rede }\end{array}$ & Efetiva & Contratado & Contratado \\
\hline
\end{tabular}

Fonte: elaboração dos autores

Para analisar os dados gerados nesse estudo, utilizamos a técnica da análise de conteúdo (BARDIN, 2011), que nos possibilitou categorizar e descrever os dados obtidos

2 O professor Mário possuía três anos de experiência como estagiário e dois como professor contratado. 
e inferir informações. Nesse sentido, como objetivávamos interpretar os dados explícitos e, além desses, os conteúdos implícitos nos documentos construídos por meio da transcrição das falas dos professores envolvidos na pesquisa, seguimos as etapas sugeridas por Bardin (2011): a) pré-análise; b) exploração do material; c) tratamento dos dados, inferência e interpretação.

No entanto, esse método não constitui um procedimento rígido e fechado em si mesmo, mas um procedimento flexível, que permite ao pesquisador construir seus próprios caminhos de observação dos dados. Porém, tais caminhos são construídos de acordo com a organização das etapas mencionadas.

\section{Livros didáticos de Português: processos e critérios de escolha}

\section{O processo de escolha}

Um dado importante que emergiu em meio as interações entre os professores participantes do GF diz respeito à análise que eles fizeram dos volumes das coleções de LDP quando chegavam à escola. Essa análise ocorreu em dias que antecederam o momento da escolha e aconteceu, primeiro, de modo individual e, depois, coletivamente. Em outras palavras, cada docente, ao receber as coleções, analisava-as individualmente e, posteriormente, socializava com os demais as suas impressões e opiniões a respeito do material recebido. Essas socializações aconteceram durante os intervalos (recreio) ou ao final do dia. Porém, devido à incompatibilidade de horário dos professores, nem sempre era possível que todos se reunissem 
para discutirem qual coleção seria mais apropriada para ser escolhida. Tais impressões foram reconhecidas ao analisarmos os depoimentos concedidos pelos professores, conforme apontam os extratos a seguir:

Moderadora: Como aconteceu o processo de escolha do livro didático?

Professor Felipe: /.../ na verdade, cada professor analisou individualmente o livro, levou também pra casa, observou os textos, as propostas de atividades e depois o consenso.

Professora Alice: Veja só, como os dias dos professores nem sempre coincidem, então a gente sempre, nos momentos... “E aí, professor Mário, já analisou? "Não". Então vamos parar no final do dia pra gente ver direitinho. "E aí, você gostou mais de qual? Oh, eu tô gostando desses dois. E você?" Então, assim, havia sempre essa discussão nos intervalos. E assim... os que se encontravam já iam entrando num consenso, depois a gente ouviu a opinião de outros professores que não estavam naquele momento. Mas (...) o tempo foi se esvaindo. Não que a gente se sentiu forçado por conta do tempo, não. $O$ problema foi de encontro mesmo!(...). Então, assim, houve divergência em relação a Mário e tudo mais (informações verbais). 
Esses dados apontam que o processo de escolha do LD não aconteceu aleatoriamente, visto que os docentes buscaram "(re)criar" espaços, momentos ou mesmo possibilidades para analisar e discutir sobre o LDP a ser adotado. Entretanto, a fala da professora Alice parece revelar que, além de ter havido opiniões divergentes entre eles acerca das coleções de LDPs analisadas, o tempo para que pudessem se encontrar e discutir sobre o material recebido não foi satisfatório.

A reflexão sobre esses dados permite inferir que, apesar das limitações impostas pelo tempo e horários dos professores, questões essas inerentes aos fatores condicionantes de cada instituição escolar (TARDIF, 2008), os docentes demonstraram autonomia para decidir qual livro seria usado por eles em sala de aula. Isso fez com que a escolha desse recurso não fosse reduzida a uma resposta exigida pelas políticas educacionais, mas, sim, uma atividade que mobilizou os professores. Nessa ótica, concordamos com Menezes et al (2012, p.4) quando declaram que "a escolha do LD [...] deve ser, portanto, um exercício de autonomia pedagógica do professor, que, de acordo com seus próprios princípios, pode escolher e decidir um valioso apoio para sua prática".

Quanto à discordância de opiniões sobre a coleção que seria escolhida, o extrato a seguir ilustra essa discussão:

Mário: (...) Nos reunimos numa quarta-feira e nos sentamos e escolhemos, com apoio de uma coordenadora pedagógica que não faz mais a coordenação conosco, que é professora M. Ela fez a fala, pelo livro 
que nós adotamos, onde eu e uma outra profissional, professora ... é... Nós havíamos optado pelo Singular $\&$ Plural, que foi um dos livros, dos produtos abordados numa dessas formações e nós gostamos.

Felipe: É da Moderna esse [livro]?

Mário: Esse Singular \& Plural é da Moderna. Aí houve a escolha pela maior parte, né? Professor A, professor C...

Alice: A diferença foi só de um voto, né?

Mário: De um voto, para a coleção Viver Juntos. Para Viver Juntos, que é da editora $\mathrm{SM}$, que é vinculada à editora Moderna, mas na verdade não é editora Moderna (informações verbais).

A análise desses dados permite-nos perceber que a organização dessa reunião, com presença da coordenadora, não inibiu que houvesse divergência de opiniões entre os mestres. Essa discordância provavelmente iniciou-se devido aos desencontros de horários entre os docentes, o que pode ter dificultado o compartilhamento de informações e opiniões sobre as coleções, e prevaleceu mesmo durante a reunião dedicada à efetivação da escolha, na qual três professores optaram pela coleção "Para 
Viver Juntos", da editora SM, e dois professores preferiram a coleção "Singular \& Plural", da editora Moderna.

Para que pudéssemos obter uma visão geral dessas coleções, organizamos o quadro a seguir, a partir das resenhas das coleções apresentadas no Guia de Livros Didáticos:

Quadro 2- Visão geral das coleções didáticas que os (as) professores (as) indicaram para escolha

\begin{tabular}{|c|c|c|}
\hline $\begin{array}{l}\text { Eixos de } \\
\text { ensino }\end{array}$ & $\begin{array}{l}\text { Para Viver Juntos: } \\
\text { português }\end{array}$ & $\begin{array}{l}\text { Singular e Plural - } \\
\text { Leitura, Produção e } \\
\text { Estudos da Linguagem }\end{array}$ \\
\hline Leitura & $\begin{array}{l}\text { O trabalho é desenvolvido } \\
\text { "por meio de uma coletânea } \\
\text { textual que favorece } \\
\text { experiências significativas } \\
\text { para a formação do leitor" } \\
\text { (BRASIL, 2013, p.76) e } \\
\text { articula-se com as atividades } \\
\text { de produção escrita. }\end{array}$ & $\begin{array}{l}\text { Desenvolve o trabalho a } \\
\text { partir de vários gêneros } \\
\text { textuais, e "contempla } \\
\text { estratégias produtivas no } \\
\text { processo de formação de } \\
\text { leitores" (BRASIL, 2013, } \\
\text { p.105). }\end{array}$ \\
\hline $\begin{array}{l}\text { Produção } \\
\text { de textos } \\
\text { escritos }\end{array}$ & $\begin{array}{l}\text { As atividades de produção } \\
\text { valorizam "os usos sociais } \\
\text { dos gêneros e explicitam } \\
\text { seu contexto de produção" } \\
\text { (BRASIL, 2013, p.77). }\end{array}$ & $\begin{array}{c}\text { As atividades de } \\
\text { produção articulam-se } \\
\text { às atividades de leitura. } \\
\text { A coleção oferece } \\
\text { orientações para que as } \\
\text { atividades de produção } \\
\text { sejam realizadas. Essas } \\
\text { atividades consideram } \\
\text { os aspectos referentes à } \\
\text { "esfera, ao suporte, ao } \\
\text { gênero e ao destinatário" } \\
\text { (BRASIL, 2013, p.108). }\end{array}$ \\
\hline
\end{tabular}




\begin{tabular}{|c|c|c|}
\hline $\begin{array}{l}\text { Eixos de } \\
\text { ensino }\end{array}$ & $\begin{array}{c}\text { Para Viver Juntos: } \\
\text { português }\end{array}$ & $\begin{array}{l}\text { Singular e Plural - } \\
\text { Leitura, Produção e } \\
\text { Estudos da Linguagem }\end{array}$ \\
\hline Oralidade & $\begin{array}{l}\text { Assim como os demais } \\
\text { eixos, também enfatiza o } \\
\text { trabalho sobre os gêneros } \\
\text { textuais. Para tanto, são } \\
\text { apresentadas ao aluno } \\
\text { estratégias e procedimentos } \\
\text { para a produção do discurso } \\
\text { oral, que favorecem o } \\
\text { desenvolvimento das } \\
\text { “habilidades linguísticas } \\
\text { dos alunos” (BRASIL, 2013, } \\
\text { p.74). }\end{array}$ & $\begin{array}{l}\text { Valoriza o trabalho com } \\
\text { os diversos gêneros } \\
\text { textuais e articula-se com } \\
\text { as atividades de leitura } \\
\text { e escrita. De acordo com } \\
\text { o GDL a "oralidade é } \\
\text { intensamente explorada } \\
\text { desde a abertura das } \\
\text { unidades, em atividades } \\
\text { que envolvem interação } \\
\text { em sala de aula" } \\
\text { (BRASIL, 2013, p.108). }\end{array}$ \\
\hline $\begin{array}{l}\text { Análise } \\
\text { Linguística }\end{array}$ & $\begin{array}{l}\text { A perspectiva predominante } \\
\text { é a textual discursiva, } \\
\text { apesar de haver } \\
\text { algumas recorrências de } \\
\text { metalinguagem. De forma } \\
\text { geral, favorece a análise e } \\
\text { reflexão sobre o uso dos } \\
\text { recursos linguísticos nos } \\
\text { diversos contextos de leitura } \\
\text { e produção. }\end{array}$ & $\begin{array}{c}\text { O tratamento desse eixo } \\
\text { de ensino ocorre em um } \\
\text { caderno exclusivo, mas } \\
\text { também é retomado } \\
\text { em algumas atividades } \\
\text { de outros cadernos. } \\
\text { Segundo o Guia os LDs } \\
\text { dessa coleção favorecem } \\
\text { a análise e reflexão sobre } \\
\text { a língua, entretanto, } \\
\text { no segundo caderno } \\
\text { onde é tratado esse eixo } \\
\text { de ensino, predomina } \\
\text { uma perspectiva } \\
\text { metalinguística } \\
\text { (classificações e } \\
\text { nomenclaturas). Sobre } \\
\text { esse aspecto o aponta que } \\
\text { Guia “A apresentação } \\
\text { desse eixo em um } \\
\text { caderno específico pode } \\
\text { dificultar sua articulação } \\
\text { com os demais” (BRASIL, } \\
\text { 2013, p.105). }\end{array}$ \\
\hline
\end{tabular}

Fonte: elaboração dos autores. 
Conforme as informações expostas no quadro, observamos que as coleções que dividiram as opiniões dos docentes participantes no processo de escolha pareciam valorizar o trabalho com os gêneros textuais/discursivos e tentar promover atividades de análise e reflexão sobre a língua, embora haja recorrências de atividades de classificação e identificação de palavras. Entretanto, na coleção "Singular e Plural- Leitura, Produção e Estudos da Linguagem", essas ocorrências parecem ser mais evidentes, uma vez que o Guia aponta que a perspectiva adotada é predominantemente transmissiva, além de o tratamento das atividades de gramática/análise linguística ocorrer em um caderno à parte não facilitar a articulação com os demais eixos de ensino. Desse modo, pressupomos que a preferência dos docentes por essas coleções pode se relacionar ao modo como cada um deles compreende o ensino da língua portuguesa.

Nesse aspecto, esses dados assemelham-se com os resultados obtidos na pesquisa realizada por Lerner (2004), na qual constatou que os professores selecionam LDPs cujo modo de tratar os conteúdos identifica-se com suas concepções teórico-práticas sobre o ensino. Sobre essa perspectiva, a pesquisadora constatou que "os professores escolhem livros que garantem certa segurança, porque confirmam seu saber-fazer" (p.117). Isso pode justificar o fato de um professor gostar do LDP que foi adotado pela escola, enquanto outro docente, da mesma instituição, expressar verdadeira aversão a esse recurso didático, uma vez que não concorda com as propostas de atividades que ele apresenta, conforme parece ter sido o caso dos professores que aqui investigamos. 
A ausência do Guia no processo de escolha e a participação das editoras

Ao conversarmos com os professores sobre como aconteceu a escolha do LDP, observamos que os mestres não mencionaram se haviam consultado o Guia de Livros Didáticos do PNLD antes ou durante a reunião destinada à escolha. Diante disso, fizemos a seguinte indagação:

Moderadora: Vocês consultaram o Guia que o MEC encaminha para a escola com a avaliação?

Professora Alice: Não.

Moderadora: Mas o Guia mesmo, vocês não viram? Veio para a mão de vocês?

Professora Alice: Não.

Professor Mário: Não chegou.

Professor Felipe: Não. Na verdade a gente só analisou em relação também só ao currículo, só isso, mas em relação ao guia não.

Professora Alice: Apesar de todo cuidado com a escolha do livro, ainda tá deixando a desejar. Apesar de toda preocupação, tanto das editoras, quanto dos professores, quanto da parte pedagógica da escola, dos orientadores e tudo mais, ainda há falhas, 
não é? A gente vê nesse sentido de um acordo único pra estudar aquilo ali, pra ver os prós e contras, pra pegar esse guia, e essa preocupação de ir à internet e ver as opiniões de outros, de mestres ou de outros colegas de mesma área (informações verbais).

Tais dados evidenciam que o Guia do Livro Didático foi um elemento ausente no processo de escolha do LD nessa escola, pois os professores não o consultaram nem antes, nem durante a escolha. Segundo eles, suas decisões foram fundamentadas na análise das próprias das coleções e nas Orientações Teórico-Metodológicas (OTMs), as quais constituem um documento curricular da Secretaria Estadual de Educação - PE com indicação de conteúdos de ensino por componente curricular e ano de ensino.

Sobre esse aspecto, salientamos que os depoimentos dos docentes não revelaram indícios de que a escola teria recebido ou não o Guia, porém esclarecem que, na ausência dele, outros suportes e/ou agentes estiveram presentes, como, por exemplo, a consulta às OTMs e, conforme será observado mais adiante, a participação das editoras.

Tais dados remetem aos resultados das já citadas pesquisas desenvolvidas por Costa Val (2002) e Batista (2004), as quais constaram que a maioria dos professores investigados preferiu consultar as coleções de LDs recebidas, em vez de recorrer ao Guia de Livros Didáticos para nortear suas escolhas. Essa realidade também emergiu entre os dados obtidos na pesquisa de Oliveira (2013), que teve como objetivo descrever, analisar e compreender como professoras de $6^{\circ}$ e $9^{\circ}$ ano do ensino fundamental 
apropriaram-se dos livros didáticos da coleção "Tudo é Linguagem", adotada no triênio 2008- 2010, em uma escola estadual de Belém - PA. Nesse estudo, a pesquisadora mencionada observou que as professoras não consultaram o Guia no momento da escolha e fundamentaram sua opção pelo LDP nas consultas às coleções que foram encaminhadas pelas editoras.

Se compararmos os resultados apresentados pelas pesquisas de Costa Val (2002); Batista (2004); Oliveira (2013) com os dados de nosso estudo, considerando o distanciamento e/ou a aproximação temporal entre elas, observaremos que, apesar da gradativa expansão do PNLD nas duas últimas décadas, ainda há professores de língua portuguesa atuantes em escolas brasileiras que não consultam o Guia do LD. Essa consulta parece não estar ocorrendo seja porque esse catálogo não chega às escolas em tempo hábil, seja porque, quando chega, fica guardado e não é entregue aos professores ou, ainda, porque os mestres parecem desconhecer o fato de que esse material pode ser consultado na internet ou preferem mesmo não o utilizar.

Contrapondo-se à ausência do Guia, a análise dos dados apontou que a participação de algumas editoras no processo de escolha do LD foi intensa, uma vez que elas tanto encaminharam representantes para visitarem as escolas com a finalidade de divulgar as coleções didáticas, quanto ofereceram "formações" para os docentes. Eis os extratos que apontaram esses dados:

Professor Mário: É ... nós recebemos a visita do representante da editora em um momento pontual da nossa rotina.

$\mathrm{O}$ representante ou a representante, 
porque foram mais de duas editoras. Eles marcavam encontros pontuais em que nós podíamos analisar o material e, quando nós analisávamos o material, nós fazíamos anotações em papeis pra comparar o que esse livro tinha que aquele não tinha e confrontávamos com as OTMs para aquela série. Então isso ocorreu do sexto ao nono ano com o professor C, professora A, professora $\mathrm{D}$ e professora E, que não está presente agora.

Professora Alice: Complementando aí ... a representante, ela ... ela mostrava ... o que determinado ... vamos dizer ... produto oferecido por ela ... Existiu todo aquele trabalho, né? De apresentação mesmo. E ela dizia ... ela mostrava a atualização, se o livro foi modificado, se a edição renovada agora trouxe alguma coisa a mais. Então isso tudo pesa também! A apresentação da representante em si também é levada em consideração, tipo é ... o tempo dispensado pra determinada reunião, a organização, o que nos ofereceu. Então há representantes que não oferecem. Houve uma representante de uma das editoras que inclusive deu uma formação diferenciada em outro local para os professores da área. 
Professor Mário: Teve um outro formador de uma outra editora que nos convidou para fazer a formação num local específico da cidade, num hotel, e ... essa formação ela trazia ... ela fazia uma via de mão dupla: ela tanto mostrava um produto ofertado e quais os diferenciais desse produto, quanto nos trazia uma formação em língua portuguesa, mostrando em que aspectos aquele produto nos serviria. Então foram duas formações. [...] Quem foi dos nossos profissionais de português pra formação que houve no hotel que era a editora Saraiva que estava fazendo essa formação. A primeira que eu já falei foi a editora Moderna, com o tema gênero textual, gêneros textuais, e a editora Saraiva trabalhou muito os gêneros textuais nos instrumentos didáticos. Então ela colocou numa apresentação no data show com os eixos do MEC. Quem foi viu, mas ela pincelou (informações verbais).

Nesse contexto, percebemos que as editoras participaram do processo de escolha do LDP, por meio de reuniões organizadas pelos seus representantes para apresentar as coleções didáticas aos professores. Nessas ocasiões, esses representantes faziam exposições sobre as inovações ou mudanças que os LDPs apresentavam, o que demonstra 
uma tentativa, por parte das editoras, de persuadir os mestres a escolherem a coleção em questão.

Outro aspecto que merece ser observado nos depoimentos expostos anteriormente é que os mestres aproveitavam esses encontros com os representantes das editoras para se reunirem e observarem se a coleção didática que estava sendo oferecida contemplava os conteúdos curriculares propostos pelas OTMs. Sendo assim, essas reuniões pareciam constituir, para os docentes, mais uma oportunidade para análise e discussão sobre as coleções de LDP, uma vez que o tempo destinado exclusivamente para essas finalidades era limitado.

Além disso, as falas dos professores apontaram que a divulgação das coleções de LDPs não foi restrita a essas reuniões, uma vez que algumas editoras, sob a pretexto de divulgar as coleções didáticas, promoveram outros encontros com os docentes em ambientes externos às escolas para influenciar os professores na escolha. Além disso, a análise dos depoimentos dos colaboradores da pesquisa parece revelar que os mestres caracterizaram esses eventos como de divulgação dos LDs, mas também como momentos de formação continuada, pois algumas editoras contrataram, como uma estratégia adicional, especialistas para oferecerem cursos, que abordavam alguns conteúdos curriculares do ensino de língua portuguesa, à medida que apresentavam os LDPs.

Esses dados remetem à pesquisa desenvolvida por Costa Val (2002), na qual se constatou que a participação das editoras era acentuada no processo de escolha dos livros, pois, quando elas não se faziam presentes por meio da visita dos representantes, suas presenças eram materializadas por meio dos catálogos, cartazes e cursos 
que divulgavam as coleções. Ao fazer esse trabalho, essas empresas exerciam, consequentemente, maior influência que o Guia no momento da escolha.

\section{Os critérios considerados no momento da escolha da coleção de LDPS}

\section{Adequação do LDP às OTMs}

A análise dos dados evidenciou que um dos critérios utilizados pelos professores para escolher as coleções didáticas parece ter sido a adequação da coleção às OTMs. Como já dissemos anteriormente, no processo de escolha, os docentes observavam se as coleções didáticas que haviam recebido para análise contemplavam os conteúdos e indicadores de desempenhos propostos pelas OTMs. Eis as falas dos docentes que nos permitiram fazer essa interpretação:

Moderadora: Qual foi o critério, o principal critério que vocês utilizaram pra dizer: É esse livro aqui, não é esse. O que mais chamou a atenção de vocês nos livros ao optar por aquela coleção?

Professor Felipe: Na verdade, a gente só analisou em relação também só ao currículo, só isso, mas em relação ao guia não. 
Professor Mário: Eu acho que vai ser sucinta a nossa fala, assim rápida, e vai ser comum. A OTM, nós recebemos o parâmetro, num é Alice? Num é Felipe? E os livros que os colegas escolheram, que foi uma boa escolha também. Isso é assim ... Como eu vou dizer... Isso é, independentemente de minha escolha ter sido outra, foi uma boa escolha. Nós utilizamos, os meninos [os professores] utilizaram a questão de pegar a OTM pra ver o que era preciso. Eu lembro quando a professora Alice, na quarta-feira, pegou e [disse]: "Olha, esse aqui num tá de acordo, em comum acordo com esse livro. Esse aqui tá em comum acordo com esse livro". Porque a série que ela trabalha era justamente o oitavo ano, nono ano. Mário também: "Olhe, tá em comum acordo isso e isso". E é esse o padrão e eu creio, nós cremos em uníssimo que o padrão que se adequa, coordenadora, é esse [simulou como ocorreu a indicação do LDP a coordenadora]. E foi feito a escolha assim (informações verbais).

Ao analisarmos tais depoimentos, notamos que os professores, ao escolherem o LDP, preocuparam-se em observar a coleção na qual os conteúdos abordados mais se aproximavam dos conteúdos indicados pelas OTMs 
para serem ensinados em cada ano de ensino. Esses dados parecem revelar que, enquanto a consulta ao Guia foi uma ação ausente no processo de escolha dos LDPs nessa escola, a consulta às OTMs foi uma das ações que influenciaram diretamente os docentes a optarem pela coleção "Para Viver Juntos: Português", opção essa que não foi a de todos, mas que prevaleceu por ter sido definida pela maioria dos docentes.

Nesse sentido, pressupomos que essa influência das OTMs sobre a escolha do LDP deu-se em decorrência do monitoramento dos conteúdos trabalhados em cada bimestre do ano letivo, o qual é realizado ao final de cada unidade, por meio do Sistema de Monitoramento de Conteúdos (SMC) da Secretaria de Educação do Estado de Pernambuco.

A partir desse pressuposto, inferimos que havia certa preocupação, por parte dos professores, em desenvolver um trabalho em torno dos conteúdos estabelecidos pelas OTMs. Essa preocupação também foi constatada na pesquisa desenvolvida por Cavalcanti; Silva e Suassuna (2014), que perceberam o caso de duas professoras que buscavam trabalhar os conteúdos propostos pelas OTMs em virtude do monitoramento de conteúdos que era realizado.

Entretanto, não podemos afirmar que o livro escolhido contemple todos os conteúdos sugeridos pelas OTMs ou mesmo que os professores seguem à risca as recomendações constantes nesse documento, pois compreendemos que as situações vivenciadas no interior da sala de aula nem sempre refletem o que é estabelecido pelos programas de ensino. Apoiando-nos em autores como Chartier (2007); Duran (2008) e Ferreira (2007), compreendemos 
que há certa distância entre as determinações pedagógicas e o que realmente é vivenciado no interior da sala de aula.

\section{Adequação do LDP à realidade dos estudantes}

Outro critério utilizado pelos professores para definir a coleção didática a ser adotada foi a adequação dela à realidade dos estudantes. Para tanto, os professores, ao analisarem as coleções de LDPs, também atentaram para observar, além dos aspectos já abordados, algumas características presentes nas coleções, como, por exemplo, o material textual disponibilizado, as imagens, a atualização, entre outros aspectos que foram mencionados pelos docentes, os quais podem ser percebidos nos depoimentos a seguir:

Professora Alice: Particularmente, existe em mim uma preocupação nesse sentido de... de tornar o livro didático mais próximo possível do mundo em que nosso alunado se encontra hoje. As ilustrações, os textos, a relação... a contextualização, num é? Da gramática, o trabalho mesmo carinhoso. Até a ilustração eu levo em consideração. É... o... os anexos, as sugestões, o anote, é... sugestões de filmes, sugestões de outras leituras. Eu levo em consideração isso. [...] . 
Professor Felipe: É até porque assim, Alice, o nosso público, o publico da nossa escola ele é muito assim...: "Professor, e aí? O que que vai ter hoje? Ô, num tô afim de copiar no livro não" [exemplificando a fala do aluno]. Mas o livro tem que ter realmente uma... uma coisa que chame a atenção (informações verbais).

Diante dessas falas, notamos que, no momento de análise e escolha do LDP, os professores preocuparam-se em observar tanto o modo como as coleções didáticas tratavam os conteúdos, quanto as sugestões de leitura e filmes e imagens disponibilizadas. Além disso, observaram se os LDPs apresentavam atualizações e abordavam temas que se aproximavam do repertório cultual em que os alunas/ os estavam inseridos.

Desse modo, percebemos que a consideração desses itens constituiu mais um critério no qual os professores se apoiaram para escolher o LDP "Para Viver Juntos". Esse critério também foi reconhecido no estudo exploratório desenvolvido por Costa Val et. al. (2004), que investigaram os processos de escolha de LDs de alfabetização e língua portuguesa de ( $1^{\mathrm{a}}$ a $4^{\mathrm{a}}$ séries) por professores de escolas brasileiras. Ao objetivar compreender os padrões e os condicionantes dessas escolhas, constataram que a adequação do LDP aos estudantes que irão utilizá-los é um dos fatores decisivos no momento da escolha. Entretanto, o referido estudo destaca que é necessário analisar se esse critério, na realidade, não mascara outro fator: a subestimação da capacidade linguística e cognitiva dos estudantes. 
Ao relacionarmos os dados produzidos no estudo de Costa Val et. al. (2004) e os produzidos na realização dessa sessão de grupo focal, compreendemos que, apesar do marco temporal que separa as duas pesquisas, e, independentemente do nível de ensino em que o professor atua, o modo como as/os alunas/os se relacionariam com o LDP parece ser um dos fatores determinantes no momento da escolha.

\section{Relação do professor com o LDP}

Os professores, ao realizarem a escolha do LDP, pareciam buscar também identificar qual coleção didática poderia melhor facilitar a organização do seu trabalho na dinâmica do cotidiano da sala de aula, bem como subsidiar a gestão das diversas atividades com as quais se deparam diariamente. Eis um dos fragmentos que permitiu realizar essa análise:

Professora Alice: Assim, porque o professor Ele ... ele tá limitado também ao tempo, num é? O nosso tempo é muito corrido. Então, quando a gente vê o livro como um instrumento riquíssimo, então quanto mais ... Vamos dizer ... quanto mais rica, quanto mais é ... quanto mais facilitador, vamos dizer assim, do nosso dia-a-dia, para com nosso trabalho mesmo literário, é ... gramatical, linguístico. $\mathrm{O}$... o livro que nos oferecer essa ferramenta, vamos dizer assim, 
facilitando a compreensão, facilitando essa comunicação, trazendo esse atrativo no sentido de linguagem, de menos formalidade, vamos dizer assim, é esse livro que assim ... que a gente se apaixona (informações verbais).

Diante da declaração, percebemos que, para a professora Alice, o LDP necessita constituir-se como um material que colabore para organização do tempo pedagógico em sala de aula, de modo que a sua utilização possa facilitar o trabalho docente ao abordar os objetos de ensino de língua portuguesa.

Esses dados parecem revelar que o professor, ao adotar um LDP, espera que esse recurso apresente elementos que ofereçam múltiplas possibilidades de atuação do docente no que se refere aos objetos de ensino, por meio de uma linguagem acessível, que favoreça a comunicação entre aluno e professor e entre os estudantes e os conteúdos curriculares, como também apresente elementos que despertem o interesse dos alunos.

Quanto às contribuições proporcionadas pelo LDP ao trabalho do professor por meio das sequências de atividades sugeridas, Lerner (2004) destaca três pontos a serem observados. O primeiro relaciona-se à importância do LDP auxiliar o professor a conduzir a aula, oferecendo um conjunto de atividades que os alunos possam solucionar de forma mais independente, o que contribuirá para que o docente tenha mais tempo para atender aqueles que necessitam receber mais assistência. $\mathrm{O}$ segundo refere-se à necessidade de o LDP colaborar com a organização 
do tempo do professor no que se refere ao planejamento das atividades. O terceiro, por sua vez, vincula-se ao LD como fonte de informações acerca dos conhecimentos a serem estudados na sala de aula, de maneira que, além de favorecer a didatização desses conhecimentos, permita uma aproximação pessoal entre o aluno e os conteúdos estudados.

Pelo exposto, compreendemos que, tanto para a referida autora, quanto para a professora Alice, o LDP não se constitui como uma ferramenta didática que engessa as práticas de ensino, mas, sim, como um recurso que pode colaborar para a organização dessas práticas, possibilitando ao professor intervir do modo mais adequado ante a diversidade de situações que podem ser vivenciadas na sala de aula.

Nesse sentido, pressupomos que os docentes não constroem com o LDP uma relação de subserviência, mas, sim, de autonomia, uma vez que seus saberes possibilitam escolher se utilizarão ou não o LD e como o usarão, o que dependerá tanto da realidade de sala de aula, quanto dos elementos apresentados pelo LD.

\section{Considerações finais}

Os resultados do estudo que desenvolvemos evidenciaram que, apesar da autonomia exercida pelo docente ao escolher os LDPs, o processo de escolha parecia ocorrer de forma de não planejada, uma vez que os professores não dispunham de tempo e espaços apropriados para analisar e discutir sobre as coleções didáticas. Além disso, a atuação das editoras esteve presente nesse processo de 
escolha, enquanto o acesso ao Guia de Livros Didáticos pareceu restrito ou inexistente.

Quanto aos critérios utilizados para escolher o LDP, percebemos que os professores, valorizavam, principalmente, a adequação do material ao documento que regulava os conteúdos curriculares na rede ensino (as OTMs) e a sua pertinência (ilustrações, material textual, conteúdos, etc.) ao grupo de alunos com o qual atuavam. Além disso, os professores também pareciam selecionar livros que facilitassem a organização de seu trabalho pedagógico em sala de aula.

Com base na discussão apresentada, acreditamos que é necessário desenvolver ações que orientem as escolas a organizar melhor o processo de escolha do LDP, de forma que os gestores e coordenadores promovam encontros mais sistemáticos para que os professores possam dialogar melhor sobre a escolha do LD. Nessas situações, além de analisar as coleções, eles podem tomar conhecimento sobre as informações relativas ao Guia, inclusive a de que ele é disponibilizado para acesso na internet. Sobre esse aspecto, é importante salientar, porém, que a consulta ao Guia não invalida a análise das próprias coleções didáticas pelos professores, a quem cabe decidir sobre a adequação ou não do livro.

Sendo assim, concordamos com as palavras de Rojo (2006, p.51), quando observa que "o momento da escolha do livro faz parte de um cenário de arrumação da sala de aula e da escola para receber seus protagonistas mais importantes: seus alunos". Desse modo, acreditamos ser necessário que os docentes escolham um LDP que ofereça melhores condições de ensino e aprendizagem aos estudantes, o que requer que o momento da escolha seja 
organizado com tempo suficiente para que os mestres discutam sobre o livro a ser adotado, estabeleçam critérios para realizar a escolha, como também tenham acesso ao Guia e demais informações sobre o PNLD.

\section{REFERÊNCIAS}

ALBUQUERQUE, E. B. C. de; COUTINHO, M. L. Atividades de leitura nos livros didáticos de língua portuguesa. In: BARBOSA, M. L. F. de F.; SOUZA, I. P. de. (Orgs) Práticas de leitura e escrita no ensino fundamental. Belo Horizonte: Autêntica, 2006.

BARDIN, L. Análise do conteúdo. São Paulo: Edições 70, 2011.

BATISTA, A. A. G. O processo de escolha de livros: o que dizem os professores. In: BATISTA, A. A. G.; VAL, M. G. C. (Orgs) Livros de alfabetização e língua portuguesa: os professores e suas escolhas. Belo Horizonte: Ceale: Autêntica, 2004.

BATISTA, A. A. G.; COSTA VAL, Maria das G. Livros didáticos, controle do currículo, professores: uma introdução. In: BATISTA, A.A.G; VAL, M. G. C. Livros de alfabetização e de português: os professores e suas escolhas. Belo Horizonte: Ceale: Autêntica, 2004.

CASTANHEIRA, M. L. et. al. Processos de escolha, recebimento e uso de livros didáticos nas escolas públicas do país. Anais da 25 a Reunião Anual da ANPEd. Caxambu: ANPEd, 2002. 
CHARTIER, A. M. Práticas de leitura e escrita: história e atualidade. Belo Horizonte: Ceale/ Autêntica, 2007.

COSTA VAL, M. G. Os processos e critérios subjacentes a escolha do livro didático nas escolas públicas do País. In: Anais da 25 a Reunião Anual da ANPEd. Caxambu: ANPEd, 2002.

COSTA VAL, M. G. et. al. Padrões de escolha de livros didáticos e seus condicionantes: um estudo exploratório. In: BATISTA, A. A. G.; VAL, M. G. C. (Orgs) Livros de alfabetização e língua portuguesa: os professores e suas escolhas. Belo Horizonte: Ceale: Autêntica, 2004.

COSTA VAL, M. G. Sobre o PNLD. In: COSTA VAL, M. G. Alfabetização e língua portuguesa: livros didáticos e práticas pedagógicas. Belo Horizonte: Autêntica: Ceale/ FaE/UFMG, 2009. (Coleção Linguagem e Educação).

DURAN, M. C. G. Ensaio sobre a contribuição de Michel de Certeau à pesquisa em formação de professores e o trabalho docente. Educação \& Linguagem, ano 10, n.15, p.117-137, jan/jun, 2007.

FERREIRA, A. T. B. O cotidiano da escola como ambiente de fabricação de táticas. In: FERREIRA, S. T. B;. ALBUQUERQUE, E. B. C. de.; LEAl, T. F. (orgs) Formação continuada professores: questões para reflexão. 2 reimp. Belo Horizonte: Autêntica, 2007.

GATTI, B. A. Grupo focal na pesquisa em ciências sociais e humanas. Brasília: Liber Livro, 2012. (Série Pesquisa). 
LERNER, D. O. Livro didático e a transformação do ensino da língua. In: BATISTA, A.A.G.; VAL, M. G. C. Livros de alfabetização e de português: os professores e suas escolhas. Belo Horizonte: Ceale: Autêntica, 2004.

MENEZES, E. A. de O. O Livro didático como política educacional e o processo da sua escolha: uma experiência em municípios cearenses. In: XVI ENDIPE - Encontro Nacional de Didática e Práticas de Ensino.Campinas: UNICAMP, 2012. Disponível em: <http://www.infoteca. inf.br/endipe/smarty/templates/arquivos_template/ upload_arquivos/acervo/docs/2169p.pdf.> Acesso em: 20 mar. 2014.

OLIVEIRA, M. A. A. O ensino de língua portuguesa: usos do livro didático, objetos de ensino e gestos profissionais. 2013. Tese (Tese de Doutorado) - Universidade Estadual de Campinas. Departamento de Linguística Aplicada no Instituto de Ciências da Linguagem. Campinas, 2013.

PAVÃO, A. C. Proposta pedagógica. O Livro didático em questão. 2006. Disponível em:< http: // www. ufpe.br/ ceel>. Acesso em: 30 dez. 2013.

ROJO, R. O livro didático de língua portuguesa. In: O livro didático em questão. 2006. Disponível em:< http: / / www. ufpe.br/ceel>1. Acesso em: 30 dez. 2013. 


\title{
ANÁLISE QUANTITATIVA DA TRADUÇÃO PARA O PORTUGUÊS DE EXPRESSÕES IDIOMÁTICAS NAS LEGENDAS DE FÃS DO SERIADO GLEE
}

\author{
Nathalia Leite de Queiroz Sátiro (UFCG/UEPB) \\ Sinara de Oliveira Branco (UFCG)
}

\begin{abstract}
A legendagem de fãs tem ganhado visibilidade no Brasil, pois quem é fã de séries não quer aguardar os canais de TV a cabo disponibilizarem os episódios com legendas em português ou dublados, uma vez que esse processo pode levar dias. Por essa razão, os fãs das séries que têm conhecimento da língua inglesa traduzem, informalmente, as legendas dos seriados que eles acompanham. As legendas produzidas por fãs se popularizaram rapidamente no Brasil, pois elas são disponibilizadas até mesmo no dia seguinte ao lançamento do episódio nos Estados Unidos. Verificamos a grande popularidade das legendas de fãs em sites, como por exemplo, o Legendas $\mathrm{TV}^{1}$, em que o seriado The Walking Dead ${ }^{2}$ bate recordes de legendas mais baixadas a cada episódio. Por esse contexto, consideramos necessário analisar a legenda de fãs, pois cada vez mais, os grupos de tradutores de legendas
\end{abstract}

1 O site Legendas TV disponibiliza as legendas de filmes e seriados feitos por grupos de legendagem de fãs.

2 Mais de cem mil fãs baixam as legendas de cada episódio do seriado norte-americano The Walking Dead. 
se organizam e criam suas próprias regras dentro da legendagem de fãs.

A atividade de legendagem é técnica e específica, tendo que se respeitar limites de caracteres por segundo, o tempo de exposição de legendas em tela, a cultura da língua de origem e de chegada, entre outros aspectos, o que pode fazer com que o tradutor de legendas precise sintetizar, adaptar o que foi dito, omitir algumas falas, para que haja tempo de leitura. As nuances do ato tradutório na produção de legendas chamou a atenção e nos fez perceber que um dos aspectos relevantes na série selecionada diz respeito às traduções de expressões idiomáticas (doravante EI).

Acreditamos que a atividade de tradução de legendas de seriados de TV é um tema que necessita de abordagem investigativa adicional, que venha a observar o resultado do trabalho tradutório de tais legendas para que possamos verificar as implicações dessas traduções na cultura brasileira, além de servir como material para cursos de tradução e insumo para pesquisa.

Pretendemos, portanto, analisar a tradução de EI em legendas de três episódios do seriado Glee, da língua inglesa norte-americana para a língua portuguesa do Brasil, produzida por uma equipe de tradutores de legendas de fãs.

Para tanto, buscamos: identificar, categorizar e quantificar as estratégias tradutórias utilizadas para a tradução de EI nas legendas. Para desenvolver este estudo, os dados foram coletados, seguindo os passos: i) seleção de legendas produzidas por uma equipe de legendagem 
de fãs ${ }^{3}$ nos episódios escolhidos e; ii) análise quantitativa das legendas feitas por fãs, com o intuito de investigar as traduções de EI.

O arcabouço teórico aqui utilizado está baseado na Tradução Audiovisual; na Legendagem; na Semiótica e Semiótica da Legendagem; nas Expressões Idiomáticas e; nas Estratégias de Tradução. Acreditamos que esta investigação poderá ajudar não apenas pesquisadores da área de tradução, como também os produtores de legendas, uma vez que é comum tradutores se depararem com EI nos textos que eles traduzem. Além disso, este capítulo pode ajudar aprendizes e professores de línguas a observarem o uso da língua através do meio audiovisual, justificando a importância desta investigação.

\section{O texto em legenda}

Daremos início a este capítulo tratando da tradução audiovisual (TAV), um campo específico nos Estudos da Tradução, no qual a legendagem está inserida. Em termos históricos, Silva (2009) afirma que a questão de

3 A equipe de legendagem de fãs aqui mencionada é a Griots Team, que é uma das equipes que se organizam para legendar filmes e seriados. As pessoas que fazem parte da equipe não são remuneradas. Os tradutores de legendas participam de treinamento antes de entrarem para a equipe. A organização da equipe e do trabalho acontece da seguinte maneira: cada episódio de seriado ou filme a ser traduzido é dividido entre cerca de seis tradutores de legendas (o número varia de acordo com a quantidade de linhas a serem traduzidas) e um ou dois revisores que padronizam os termos e corrigem os erros encontrados. Os tradutores de legendas mais experientes acabam se tornando revisores. 
combinação de sons e imagens gravados é quase tão antiga quanto o cinema. Segundo Silva (2009), a primeira exibição do cinema foi em 1895, na França, e foi a partir daí que o cinema se expandiu por toda a Europa, depois pelos Estados Unidos e pelo restante do mundo. A TAV surgiu diante dessa globalização e da necessidade de o mundo se relacionar e mostrar as diferentes culturas.

A autora divide os tipos de tradução audiovisual em: 1) dublagem, na qual nada nas imagens é alterado e se substitui o áudio original por um áudio na língua de chegada; 2) voice-over, em que o áudio original não é apagado e outro áudio na língua diferente é sobreposto; 3) legendagem, quando se utiliza um texto escrito, transmitido simultaneamente à fala; e 4) closed-captions ${ }^{4}$, que dá acessibilidade a deficientes auditivos, pois é direcionada a esse público.

Os estudos da TAV ganham destaque nos anos 2000 com Díaz Cintas e Anderman (2009) que descrevem os tipos de TAV e o seu crescimento nos últimos anos, ressaltando que um dos aspectos positivos é o acesso de pessoas com alguma deficiência auditiva ou visual aos meios audiovisuais. Os tipos de TAV, segundo os autores, são: 1) a dublagem, cuja principal meta é a sincronia entre os lábios do ator original e a voz do dublador; 2) a audiodescrição, que é a descrição gravada em voz alta e integrada ao áudio do vídeo, geralmente usada para ajudar deficientes

4 Closed-captions é uma das modalidades da TAV que faz a inclusão dos deficientes auditivos. Para a autora, os closed-captions são um tipo de legendagem e "não apenas ocorre na tradução, mas também na língua nativa, focando seu público nos portadores de algum grau de deficiência auditiva" (SILVA, 2009, p.15). 
visuais na compreensão dos vídeos; 3) a narração, que consiste em um texto descritivo traduzido, lido por um narrador sem aparecer em cena; 4) no voice-over, ouve-se a voz original em volume mais baixo e o texto oral traduzido é sobreposto; e, 5) a legendagem, que é a transposição do discurso falado em forma de texto escrito, sendo o tipo de TAV mais popular, por ser mais econômico.

No entanto, para Franco e Araújo (2011), nem todos esses tipos de tradução são do meio audiovisual. Levando em consideração o contexto desse capítulo, concordamos com as autoras de que essa divisão de tipos de TAV é extensa e que, para uma melhor compreensão delas, esses tipos devem ser reduzidos em categorias. Para Franco e Araújo (2011), os tipos de TAV são: 1) legendagem, que se subdivide em três: legendagem para ouvintes, legendagem para surdos e ensurdecidos (LSE) e legendagem eletrônica (surtitling); 2) modos de revocalização: a dublagem e o voice-over; e 3) a audiodescrição (AD). Para as autoras, a narração e a interpretação não fazem parte da modalidade da TAV - e nós concordamos com elas.

Este capítulo se atém à legendagem que, conforme Araújo (2004) é a interpretação condensada ou não das falas de um filme, seriado ou outro programa de televisão-definição da qual partilhamos. No Brasil, antes de os canais de TV a cabo se popularizarem, a legendagem estava presente apenas nos cinemas e nos vídeos domésticos. Nos dias atuais, na TV a cabo, a incidência da legendagem é maior do que a da dublagem, o mesmo não ocorre na TV aberta, uma vez que se dá de maneira inversa.

A seguir, será detalhado não só o trabalho técnico de legendagem, mas também a sua função baseada em estudos analíticos de seu papel no cinema. 


\section{Legendagem}

$\mathrm{Na}$ tradução de legendas, existem diversos obstáculos a serem enfrentados pelos tradutores de legendas. Sobre isso temos a contribuição de Gorovitz (2006) afirmando que,

O tradutor, pelas limitações técnicas impostas, deve resumir e sintetizar ao máximo o diálogo, tentando produzir uma mensagem curta e clara e tendo unidade semântica. [...] A mensagem deve estar contida em, no máximo, duas linhas de até 56 caracteres. A posição da legenda, a fonte utilizada, a cor, o tempo de exposição, a escolha de palavras facilmente apreensíveis devem respeitar regras rígidas e, assim, limitam a liberdade do tradutor. Além disso, a projeção da legenda deve ser sincronizada à imagem: a tradução precisa aparecer e desaparecer conforme a sucessão do diálogo (GOROVITZ, 2006, p.65-66).

Ou seja, para produzir legendas, o tradutor deve compreender como funcionam os aspectos da legendagem e obedecer às regras que são impostas por ela. Podemos citar como exemplo dessas regras o limite de caracteres por linha, o número máximo de linhas, o tempo em que a legenda deve aparecer em tela. Cada empresa de 
legendagem tem as suas próprias regras e manuais, que diferem das regras mencionadas por Gorovitz (2006).

Além disso, há também uma grande quantidade de elementos da oralidade que são intransponíveis no discurso escrito, por isso, é preciso destacar que a legendagem "incorpora certos traços, mas rejeita outros por querer se aperfeiçoar ao discurso oral" (RIDD, 1995, p.478). Por causa da passagem do oral para o escrito perdem-se muitas informações, pois elas, muitas vezes, não podem estar nas legendas, devido às limitações técnicas. Então, faz-se necessário omitir, mas, para isso, o tradutor de legendas tem que conhecer bem o produto, seja ele um filme, um seriado, ou outro meio audiovisual, para que saiba em que momentos se pode fazer os cortes.

Linde e Kay (2009) discutem sobre esse tema e sugerem que o tradutor de legendas avalie a relevância de cada segmento das mensagens, para que, em caso de falta de espaço na legenda, seja possível omitir informações que não causarão perdas importantes no contexto. Os autores abordam ainda alguns elementos de fala que podem parecer que não são importantes e são facilmente omitidos em legendas, como: "actually, well, you know, etc.". No entanto, se eles forem a marca de fala de algum personagem, devem ser respeitados para que não o descaracterize. Portanto, o texto da legenda é geralmente uma parte condensada do texto falado no vídeo, devido às limitações de tempo e de espaço e da velocidade de leitura do espectador. É importante também, respeitar a sincronia do áudio com a legenda, para que o leitor não leia novamente a mesma legenda uma vez concluído o áudio. Por isso, vemos o quanto é importante pensar no leitor das legendas, respeitando os aspectos citados, já que 
as legendas podem mudar o ritmo de leitura de quem as acompanha.

O foco deste capítulo é a legendagem de fãs que, em conceito, é igual à legendagem profissional, pois os tradutores de legenda também seguem regras e técnicas. Um dos aspectos que as difere é o tipo de tradutor de legendas: aquele que faz o trabalho de legendagem como profissão; e o fã que faz por hobby, assumindo uma função social. Esse papel social que o tradutor de legendas de fãs assume faz com que pessoas sem TV a cabo ou cinema próximo ao local onde vivem tenham acesso a filmes e seriados. Além disso, Carvalho (2005) assevera que, na legendagem profissional, o tradutor de legendas, na maioria dos casos, traduz a legenda apenas com base no roteiro do filme ou do seriado, não tendo acesso às imagens e ao áudio, pois as empresas podem não liberar o material com receio da pirataria. Então, podemos observar que há uma vantagem na legendagem de fãs, uma vez que o tradutor de legendas tem acesso ao vídeo e, diversas vezes, tem também acesso a uma legenda já com os tempos inclusos ou um roteiro na língua original para traduzir. Carvalho (2005) afirma ainda que, na legendagem profissional, existem diferentes profissionais envolvidos, como: os funcionários que acompanham os diálogos do roteiro do vídeo juntamente com o vídeo para indicar onde cada trecho de fala começa e termina; os tradutores, que recebem o roteiro e poucas vezes o material audiovisual e traduzem as falas em um software específico; os profissionais que ajustam a sincronia das legendas com o vídeo; os que fazem a inserção das legendas nas películas; e, por fim, a distribuidora que analisa o produto e o distribui. 
Na legendagem de fãs, normalmente, há o tradutor de legendas e o revisor. O primeiro, em posse do material audiovisual, produz a legenda utilizando um software ${ }^{5}$ específico, e ele mesmo pode fazer a sincronia das legendas com as falas; o revisor padroniza os termos, observa se as questões técnicas foram respeitadas e faz os ajustes necessários nelas e nas traduções. Vale salientar que a equipe de legendagem de fãs que produziu as legendas aqui analisadas não insere as legendas aos vídeos, ou seja, ela não pirateia o vídeo (distribuindo-o na internet), ela apenas publica a legenda feita ${ }^{6}$. Acreditamos que a legendagem de fãs seja um meio alternativo para que as pessoas tenham acesso a filmes e seriados.

Acerca do processo de legendagem no Brasil, conforme esboçado por Araújo (2004), observa-se que as pesquisas nessa área começaram a surgir na década de 1990. Quanto à classificação das legendas, elas podem ser classificadas segundo dois parâmetros: 1) o linguístico, que se subdivide em dois: a) intralingual, a legendagem na mesma língua do texto falado, e b) interlingual, a tradução dos diálogos de um filme ou programa de TV em língua estrangeira, por exemplo; e 2) o técnico, em que as legendas se subdividem em duas: a) abertas, as que são

5 O software utilizado pela equipe Griots Team é o Subtitle Workshop que será apresentado na medotologia deste trabalho.

6 Todo conteúdo produzido pela Griots Team está sob a licença Creative Commons Atribuição, Não Comercial, Compartilhamento Igual 4.0 (CC BY-NC-SA 4.0). A equipe não disponibiliza para download arquivos ou links de séries, filmes ou qualquer outro conteúdo protegido por direitos autorais. Outros detalhes acerca da equipe encontram-se no site: <http://www.griotsteam.com/>. 
sobrepostas à imagem antes da transmissão ou exibição e b) fechadas, closed-captions, cujo acesso ficará a critério do telespectador através de um decodificador de legenda localizado no controle remoto do aparelho de televisão (ARAÚJO, 2004).

As legendas aqui investigadas são legendas interlinguais, já que foram traduzidas do inglês para o português do Brasil e são abertas, pois elas, depois de produzidas, são inseridas ao vídeo pelo telespectador ou por alguém que conhece esses procedimentos. As legendas selecionadas são do seriado Glee feitas por uma equipe de fãs. Como o foco são as expressões idiomáticas produzidas a partir da fala dos personagens do seriado, direcionamos nossa análise para esse aspecto. Então, a seguir, apresentaremos conceitos importantes sobre EI que nos auxiliarão no momento de nossa análise.

\section{Expressões Idiomáticas em Contexto de Legendagem}

Ao estudar uma língua estrangeira ou ao visitar uma região e comunidade com costumes distintos dos nossos, percebemos as especificidades das expressões idiomáticas (EI), pois não há regra que as explique, seja com relação à sua formação ou ao novo sentido que as palavras juntas ganham. Além de conhecimento de léxico e da gramática de uma língua, temos que conhecer suas funções e seus sentidos, pois elas levam consigo aspectos culturais de cada lugar em que são usadas.

Para Tagnin (2005) uma EI é a expressão que não tem o seu significado transparente. Para a autora, o termo EI “englobará apenas expressões semanticamente convencionalizadas, istoé, cujo significado não pode ser depreendido 
a partir do significado de suas partes" (TAGNIN, 2005, p.64). A autora diferencia as EI de expressões convencionais, já que para ela, estas últimas possuem significado transparente. Quando as expressões deixam transparecer essa relação entre a imagem e o seu significado, Tagnin (2005) as classifica como expressões metafóricas. Para a autora, só seriam EI se essa relação de imagem aludida e significado não pudesse mais ser recuperada.

Baker (1992) discorre que as EI e expressões fixas são formas cristalizadas da língua que permitem pouca ou nenhuma variação, e no caso específico das EI, a autora destaca que elas carregam um significado que não pode ser compreendido por seus elementos individuais. Baker (1992) apresenta estratégias para a tradução de EI, tais como usar uma EI que tenha significado e forma similar; usar uma EI com significado similar, porém com forma diferente; parafrasear a EI; ou omitir a EI. Estas estratégias de tradução de EI propostas por Baker (1992) foram utilizadas para auxiliar na seleção do corpus, cuja explicação será apresentada no tópico seguinte.

Apresentamos, então, a definição sobre EI de Alvarez:

Uma expressão idiomática pode ser definida como uma unidade sintática e semântica. Ela forma uma estrutura sintagmática complexa que resulta numa unidade lexical conotativa e se refere a uma realidade específica com um sentido particular. $\mathrm{O}$ significado dela resultante independe do significado dos lexemas isolados que a compõem. Sua extensão de 
sentido é metafórica e o que mantém a unidade lexical é o todo significativo; são os lexemas gerando um novo sentido ao se combinarem que justifica a sua opacidade e o fato de serem indecomponíveis (ALVAREZ, 2011, p.123-124).

O que a autora quer dizer é que uma EI não deve ser compreendida pelo significado de cada um dos seus elementos, já que esses elementos juntos ganham um novo sentido.

A partir das definições discutidas acima e para atingir os objetivos desse capítulo, a definição de EI aqui utilizada será: uma estrutura sintagmática complexa, cujo sentido é compreendido através da unidade completa (e não dos lexemas isolados que a compõem) e do contexto cultural e geográfico. As EI podem ter sentido metafórico e em sua maioria não fazem sentido se tentarmos entender palavra por palavra isoladamente. Deve-se entender a combinação de palavras, pois ganharão um novo sentido ao se combinarem. As EI nem sempre serão indecomponíveis, uma vez que verificamos ser possível substituirmos uma palavra da EI e ela não perder o sentido idiomático, porém se quando essa substituição for feita a expressão perder o sentido idiomático, ela deixará de ser uma expressão idiomática.

Para nos auxiliar na análise das traduções das EI nas legendas, apresentaremos no subitem a seguir as estratégias de tradução propostas por Chesterman (1997). 


\section{Estratégias de tradução}

Segundo Chesterman (1997), os tradutores são pessoas especializadas em resolver certos problemas na comunicação. Para auxiliar os tradutores, o autor propõe estratégias de tradução nos níveis: sintático, semântico e pragmático.

As estratégias sintáticas são as que envolvem mudanças sintáticas, ou seja, elas manipulam as formas. As principais delas apresentadas por Chesterman (1997, p. 94-101) são: G1, Tradução literal (traduz-se o texto de chegada o mais próximo possível da estrutura gramatical do texto de partida); G2: Empréstimo, calque (se refere a uma escolha deliberada e não inconsciente); G3: Transposição (significa qualquer mudança de classe de palavra, por exemplo: de substantivo para verbo, de adjetivo para advérbio); G4: Deslocamento de unidade (ocorre quando uma unidade - morfema, palavra, frase, oração, sentença, parágrafo - do texto de partida é traduzida para uma unidade diferente no texto de chegada; G5: Mudança estrutural da frase (mudanças no nível da frase, incluindo número, exatidão e modificação na oração substantiva e na pessoa, número e tempo verbal); G6: Mudança estrutural da oração (tem a ver com a estrutura da oração em termos de suas frases constituintes); G7: Mudança estrutural de período (esta estratégia afeta a estrutura da unidade de sentença); G8: Mudança de coesão (é algo que afeta a referência intratextual, elipse, substituição, pronominalização e repetição, ou o uso de conectores e vários tipos); G9: Deslocamento de nível (em um deslocamento de nível - fonológico, morfológico, sintático e lexical-, o modo de expressão de um determinado item é modificado de um 
nível para outro); G10: Mudança de esquema (se refere aos tipos de mudanças que os tradutores incorporam na tradução de esquemas retóricos - paralelismo, repetição, aliteração, ritmo e métrica).

As estratégias semânticas, de acordo com Chesterman (1997, p.101-107), são as que manipulam os significados. São elas: S1: Sinonímia (não selecionam o equivalente óbvio, mas um sinônimo ou um termo quase sinônimo para evitar repetição por exemplo); S2: Antonímia (o tradutor seleciona um antônimo e combina com um elemento de negação); S3: Hiponímia (mudanças dentro das relações hiponímicas); S4: Conversões (são pares de estruturas verbais que expressam o mesmo sentido, porém com pontos de vistas controversos); S5: Mudança de abstração (uma seleção diferente do nível abstrato pode variar do abstrato para o mais concreto ou do concreto para o mais abstrato); S6: Mudança de distribuição (é a mudança de distribuição dos mesmos componentes semânticos para mais itens - expansão, ou para menos itens - compressão); S7: Mudança de ênfase (esta estratégia reduz ou altera a ênfase ou foco temático por uma razão ou outra); S8: Paráfrase (resulta em uma versão do texto de chegada que pode ser descrita como distante do texto de origem. componentes semânticos no nível lexical tendem a ser ignorados favorecendo o sentido pragmático de alguma outra unidade, como por exemplo: uma oração inteira); S9: Mudança de tropo (é a tradução de tropos retóricos, assim como a estratégia g10 aplicada à tradução de esquemas); S10: Outras mudanças semânticas (inclui outras modulações de vários tipos, como a mudança de sentido ou a direção de dêitica). 
Quanto às estratégias pragmáticas, Chesterman (1997, p.107-112) afirma que elas envolvem, geralmente, uma maior mudança do texto de partida e que podem incorporar mudanças sintáticas e/ou semânticas também. As estratégias pragmáticas são as que manipulam as mensagens propriamente ditas: Pr1: Filtro cultural (esta estratégia é também conhecida como naturalização, domesticação ou adaptação); Pr2: Mudança de explicitação (esta mudança é mais direcionada à informação explicita ou mais direcionada à informação implícita); Pr3: Mudança de informação (a adição de novas informações que são consideradas relevantes para o leitor do texto de chegada, porém não estão presentes no texto de partida, assim como omissão de informações); Pr4: Mudança interpessoal (esta estratégia altera o nível de formalidade, o grau de emotividade e envolvimento, o nível de léxico técnico, entre outros); Pr5: Mudança de elocução (as mudanças de elocução estão geralmente ligadas a outras estratégias, por exemplo: a mudança do modo verbal do indicativo para o imperativo (g5) também envolve uma mudança de elocução de afirmação para pedido); Pr6: Mudança de coerência (é a organização lógica da informação no texto, no nível ideacional); Pr7: Tradução parcial (este tipo de tradução abrange qualquer tipo de tradução parcial, como a tradução resumida, a transcrição, a tradução apenas dos sonhos, entre outras); Pr8: Mudança de visibilidade (diz respeito a mudança na presença de autoria ou a inclusão evidente ou em primeiro plano da presença tradutória, como as notas de rodapé, os comentários entre chaves ou os comentários adicionais explícitos); Pr9: Reedição (se refere à reedição, às vezes, radical que os tradutores precisam fazer em textos de partida mal escritos); 
Pr10: Outras mudanças pragmáticas (um dos exemplos seria mudança no layout do texto).

Após a exposição das estratégias com relação a estes três níveis sintático, semântico e pragmático, podemos dar como exemplos mais comuns: a questão da tradução literal estando no nível sintático, seguindo a forma gramatical do texto que está sendo traduzindo; a da paráfrase que se encontra no nível semântico, uma versão do texto de partida para o texto de chegada; e, o filtro cultural que está no nível pragmático, uma vez que se a frase a ser traduzida não fizer sentido para a língua de chegada, opta-se por fazer uma domesticação ou uma adaptação para o contexto da língua e da cultura do Brasil, no caso que estamos analisando.

Para contextualizar o que foi discutido, podemos ter como exemplos destes níveis e das estratégias de traduções citadas, as seguintes frases:

Quadro 1 - Trecho retirado do primeiro episódio da quinta temporada do seriado Glee

\begin{tabular}{|l|l|}
\hline Legenda original: & Legenda traduzida: \\
00:10:21,401 $\rightarrow$ 00:10:23,899 & 00:10:21,401 $\rightarrow$ 00:10:23,899 \\
You want to get to Broadway, & Se quer chegar a Broadway, \\
you have to pay your dues. & tem que pagar suas dívidas. \\
\hline
\end{tabular}

Fonte: Elaborado pelas autoras. 
Quadro 2 - Trecho retirado do terceiro episódio da quinta temporada do seriado Glee

\begin{tabular}{|l|l|}
\hline Legenda original: & Legenda traduzida: \\
00:18:37,896 $\rightarrow$ 00:18:40,715 & $00: 18: 37,896 \rightarrow 00: 18: 40,715$ \\
-You get the hell out of my office! & -Saia do meu escritório! \\
-How about you make me get & -Que tal você me fazer sair? \\
the hell out of your office? & \\
\hline
\end{tabular}

Fonte: Elaborado pelas autoras.

No Quadro 1, a personagem Santana fala com Rachel que ela precisa batalhar para chegar à Broadway. A tradução feita foi a literal, o tradutor traduziu cada elemento da EI, mantendo as estruturas do nível sintático, porém não se levou em consideração o nível pragmático, referente ao uso da EI, que neste caso seria que a personagem teria que fazer por onde conseguir, ou seja, correr atrás do sonho dela e não pagar as dívidas.

No Quadro 2 a professora Sue tenta expulsar Santana do seu escritório. No português do Brasil a tradução de "get the hell out of" não ficaria adequada se fosse feita literalmente, por isso a tradução escolhida como "saia" e "sair" se adequou ao contexto de uso, uma vez que foi levado em consideração o aspecto semântico e pragmático, mantendo-se o sentido da frase e escolhendo uma frase que está de acordo com o que os falantes do português do Brasil usam.

A seguir, apresentaremos a metodologia utilizada para alcançar os objetivos do capítulo. Para tanto, apresentaremos o seriado, discutiremos o corpus analisado, além de descrever as categorias de análise do corpus e as ferramentas de auxílio para a análise. 


\section{Sistematizando um estudo sobre legendas}

O objetivo aqui é expor a metodologia utilizada para atingir os objetivos deste capítulo.

Conhecendo o seriado Glee: os três episódios escolhidos

Glee é uma série de televisão norte-americana exibida pelo canal FOX e produzida por Ryan Murphy, Ian Brennan e Brad Falchuk. Ela teve seis temporadas, sendo a primeira iniciada no dia 19 de maio de 2009 e a última encerrada no dia 20 de março de 2015. Ao todo foram 121 episódios, da primeira à quarta temporada cada uma teve 22 episódios, a quinta temporada teve 20 episódios e a última, 13 episódios. A série é sobre jovens ambiciosos e talentosos que entram para o Clube Glee Novas Direções (o coral da escola McKinley) que é coordenado pelo professor Will Schuester (personagem de Matthew Morrison) e perseguido pela professora Sue Silvester (que odeia todos do coral). No coral, os alunos são bem diferentes uns dos outros, desde os mais populares até os mais perdedores da escola. Essa diferença é o que chama atenção do público, pois se identificam com os personagens, e mesmo os que são considerados perdedores, mostram que são capazes de vencer.

No primeiro episódio selecionado, houve 5.060 .000 espectadores, no segundo, 4.420.000 de espectadores e no terceiro episódio houve 7.390 .000 espectadores $^{7}$. As legendas produzidas pela equipe Griots Team mais aces-

7 Verificamos esse dado no site: <http://www. adorocinema.com/series/serie-4114/audiencias/\#22500_on 
sadas da quinta temporada de Glee também foram as dos três primeiros episódios, com uma média de mais de 14 $\mathrm{mil}^{8}$. Esse fato, provavelmente, ocorre porque um dos principais atores (Cory Monteith) da série morreu antes da quinta temporada ir ao ar e os fãs e público em geral quiseram ver como seria o desfecho do personagem Finn Hudson em Glee.

O primeiro episódio é intitulado, Love, love, love, e é o primeiro dos dois episódios que fizeram um tributo a banda The Beatles. O segundo episódio da quinta temporada da série foi o Tina in the Sky with Diamondss. O último episódio escolhido e terceiro da quinta temporada foi um tributo ao personagem Finn Hudson e a Cory Monteith que o interpretava e foi intitulado "The Quarterback".

\section{O corpus da análise}

Olohan (2006) define corpus como:

Uma coleção de textos, selecionados e compilados de acordo com critérios específicos. Os textos são armazenados em formato eletrônico, como em arquivos de computador, para que vários tipos de ferramentas de

_20024>. Acesso em: 16 set. 2015. O número de espectadores foi contado apenas na primeira exibição de cada episódio.

8 Os números exatos podem ser visualizados no site que publicou as legendas: <http://legendas.tv/busca/Glee/ 30742>. Acesso em: 16 set. 2015. 
corpus, como um software, possam ser utilizados para realizar as análi$\operatorname{ses}^{9}$ (OLOHAN, 2006, p. 1, tradução nossa).

Para coletarmos o corpus, assistimos uma vez a cada um dos três episódios do seriado sem legenda, assistimos três vezes a cada um dos episódios com legenda em inglês, assistimos duas vezes a cada um dos episódios com legenda em inglês e em português (com o auxílio do software Subtitle Workshop), e assistimos três vezes aos dois primeiros episódios e quatro vezes ao terceiro até conseguirmos encontrar todas as EI. A medida em que alguma EI surgia, parávamos o episódio para anotações. Decidimos não utilizar as EI que estavam nas letras das músicas cantadas pelos personagens, porque teríamos que explorar outro gênero (música) e isso fugiria do objetivo de verificarmos as EI que foram escritas no roteiro para cada um dos personagens.

Utilizamos os termos forma (type) e ocorrência (token) da Linguística de Corpus para contabilizarmos o número de EI em língua inglesa do corpus deste capítulo. A forma corresponde a cada item, sem levar em consideração a repetição de cada um, obtivemos um total de 51 formas, ou seja, 51 EI distintas. A ocorrência corresponde ao número total de itens, incluindo as repetições deles, obtivemos um total de 59 ocorrências, sendo cinco EI

9 A corpus is a collection of texts, selected and compiled according to specific criteria. The texts are held in eletronic format, i.e. as computer files, so that various kinds of corpus tools, i.e. software, can be used to carry out analysis on them (OLOHAN, 2006, p.01). 
repetidas nos episódios. Para facilitar essa contagem, criamos um quadro no Microsoft Word com as EI em ordem alfabética e as EI que se repetem foram destacadas.

Após a seleção das EI, elas foram inseridas em quadros feitos no Microsoft Word, separadas inicialmente por episódios. A primeira coluna dos quadros possui as linhas das legendas em inglês (em negrito, itálico e sublinhado), além dos nomes dos personagens que falaram e a segunda coluna possui as linhas das legendas traduzidas para o português do Brasil (em negrito e sublinhado). Como se pode observar no Quadro 3 a seguir:

Quadro 3 - Trechos retirados do segundo episódio da quinta temporada do seriado Glee

\begin{tabular}{|c|c|}
\hline Legenda original: & Legenda traduzida: \\
\hline SR. SCHUE & \\
\hline 00:00:39,151 $\rightarrow$ 00:00:41,822 & 00:00:39,151 $\rightarrow$ 00:00:41,822 \\
\hline where they literally and figuratively & fazendo que eles deixassem \\
\hline let their hair down. & os cabelos crescerem. \\
\hline TINA & \\
\hline 00:02:07,514 $\rightarrow$ 00:02:09,863 & 00:02:07,514 $\rightarrow$ 00:02:09,863 \\
\hline I need to maximize my odds & Preciso ter todas as chances \\
\hline of taking the crown, & de ganhar, \\
\hline TINA & \\
\hline 00:02:12,122 $\rightarrow$ 00:02:14,917 & 00:02:12,122 $\rightarrow$ 00:02:14,917 \\
\hline And I am going for it. & Vou batalhar por isso. \\
\hline
\end{tabular}

Fonte: Elaborado pelas autoras. 
Essa divisão feita caracteriza este corpus como paralelo e Zanettin (2000, p. 106) descreve corpus paralelo como um conjunto de traduções em uma língua e a tradução correspondente em outra língua. $\mathrm{O}$ autor afirma que o corpus paralelo pode ser utilizado para apresentar o que os tradutores fizeram, e a partir dessa comparação entre o texto original e o texto traduzido é que faremos as análises, observando quais estratégias de tradução foram escolhidas e as implicações dessas escolhas.

Para não perdermos o contexto de cada EI, contamos com o auxílio do software Bandicam para selecionarmos as cenas em que as EI estavam e as capturamos em vídeos no formato $A V I^{10}$ com legendas em português.

\section{Descrição das categorias escolhidas para a divisão do corpus}

Com a contribuição das estratégias para a tradução de EI que Baker (1992) apresenta e que já mencionamos no tópico anterior, decidimos separar o corpus em quatro categorias: 1) tradução literal de EI, perdendo-se o sentido dela; 2) tradução de uma EI por outra EI com o mesmo efeito; 3) tradução de uma EI por meio de paráfrase; e, 4) omissão da EI.

Para isso, outros quadros foram criados no Microsoft Word, um para cada categoria. Na primeira coluna apresentamos a legenda em inglês com as EI destacadas em negrito e sublinhadas; na segunda coluna, apresentamos a legenda em português traduzida pela equipe de

10 O formato AVI é um dos mais populares e é reconhecido pela maioria dos leitores de vídeos. 
legendagem de fãs com as EI destacadas em negrito e sublinhadas; na terceira coluna, tem-se a definição da EI; na quarta coluna, apresentamos a estratégia de tradução utilizada de acordo com as que Chesterman (1997) propõe; e, na última coluna, indicamos de qual episódio o trecho foi retirado.

Ferramentas de auxílio para análise

A seguir, descreveremos os dois softwares que foram usados como ferramentas para as análises de dados, o Subtitle Workshop e o Bandicam, respectivamente.

\section{Subtitle Workshop}

O Subtitle Workshop ${ }^{11}$ é um software gratuito para criar, editar e converter arquivos de legendas com base em texto. Utilizamos a versão 2.52 do software para verificar os aspectos técnicos da legendagem e foi a mesma versão utilizada pelos tradutores de legendas da equipe de legendagem de fãs Griots Team. Cursos de legendagem também o utilizam, como é o caso da GTC Treinamento ${ }^{12}$.

Para configurá-lo, seguimos os passos:

1. Abrir o Subtitle Workshop e apertar ALT + I;

2. No item "Guia Geral" deixar somente estas opções marcadas:

11 Software disponível gratuitamente para download em: <http:/ / subworkshop.sourceforge.net/ $>$.

12 Informações sobre o curso de legendagem disponíveis em: $<$ http://gtctreinamento.com.br/>. 
a. Marcar Erros na Lista do Formato Principal; b. Negrito; c. Marcar erros ao abrir a legenda.(Conforme a Figura 1)

3. No item "Guia Avançado" configurar:

a. Duração muito longa: 5000 / b. Duração muito curta: 1400 / c. Linha muito longa: 33 d. CPS superior ou igual a: 20,01 / e. Espaço após caractere: (Conforme a Figura 2)

4. No item "Verificar Por" deixar marcado conforme a Figura 3.

5. Arrastar o vídeo e as legendas para o software.

6. Utilizar os atalhos da Figura 4 para facilitar a manuseio do software.

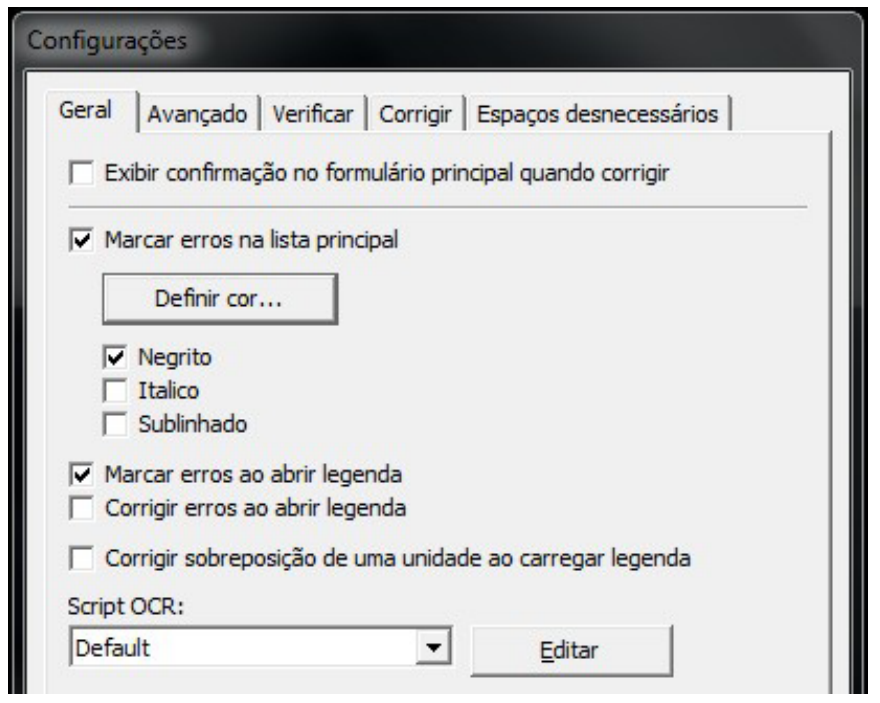

Figura 1 - Segundo passo das configurações do Subtitle Workshop Fonte: Subtitle Workshop. 


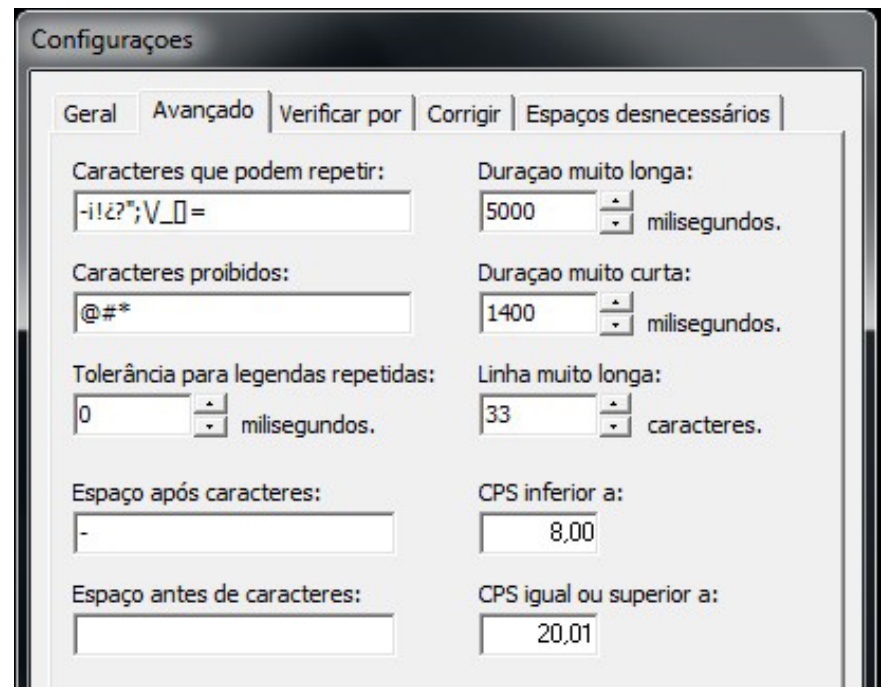

Figura 2 - Terceiro passo das configurações do Subtitle Workshop Fonte: Subtitle Workshop.

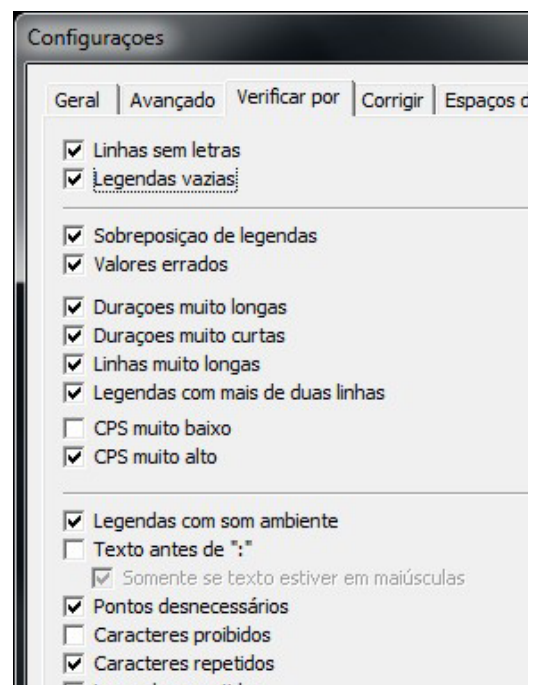

Figura 3 - Quarto passo das configurações Subtitle Workshop

Fonte: Subtitle Workshop. 


\begin{tabular}{|c|c|c|}
\hline & ATALHO & $A C \not \subset O$ \\
\hline \multirow{5}{*}{ TEMPOS } & $A L T+C$ & Define o tempo de inicio de exibição da legenda \\
\hline & $A L T+V$ & Define o tempo de término de exibiçăo da legenda \\
\hline & CTRL+SHIFT+E & Estende o tempo de duraçâo da legenda até o ínicio da outra \\
\hline & $\mathrm{CTRL}+\mathrm{SHIFT}+\mathrm{N}$ & Muda a legenda +100 milissegundos \\
\hline & $\mathrm{CTRL}+\mathrm{SHIFT}+\mathrm{H}$ & Muda a legenda - 100 milissegundos \\
\hline \multirow{4}{*}{ TEXTOS } & INSERT & Inserir nova legenda abaixo da atual \\
\hline & SHIFT+INSERT & Inserir nova legenda antes da atual \\
\hline & $C T R L+K$ & Junta as legendas selecionadas, preservando os tempos \\
\hline & $C T R L+S H I F T+D$ & Divide os textos das legendas e seus tempos \\
\hline \multirow{5}{*}{ VIDEO } & CTRL+ESPACCO & Pausa/Continua reprodução \\
\hline & $\mathrm{ALT}+\longrightarrow$ & Avança 1 segundo, se pressionado \\
\hline & $\mathrm{ALT}+\longleftarrow$ & Retrocede 1 segundo, se pressionado \\
\hline & $\mathrm{CTRL}+\longrightarrow$ & Avança 5 segundos, se pressionado \\
\hline & $\mathrm{CTRL}+\longleftarrow$ & Retrocede 5 segundos, se pressionado \\
\hline \multirow{4}{*}{ REVISĀO } & CTRL+1 & Abre janela de erros na legenda \\
\hline & $C T R L+S H I F T+Y$ & Expandir/Reduzir tempos \\
\hline & $C T R L+L$ & Determina valores mínimos e máximos de duração \\
\hline & $C T R L+D$ & Adianta/retrocede legendas (usado em resyncs) \\
\hline
\end{tabular}

Figura 4 - Sexto passo das configurações do Subtitle Workshop

Fonte: Elaborado pelas autoras.

Após os ajustes feitos nas configurações do software, deu-se início às análises dos aspectos técnicos das legendas escolhidas. O Subtitle Workshop possibilitou também que as pesquisadoras pudessem assistir aos episódios com a legenda em inglês, em seguida com a legenda em português e por fim, com as duas legendas, em português e em inglês ao mesmo tempo.

Feita a descrição do software utilizado para as questões das legendas, descreveremos, a seguir, o software que foi usado para a captura das cenas do seriado.

\section{Bandicam}

Utilizamos o software Bandicam para capturar vídeos dos episódios selecionados para que as EI não ficassem 
descontextualizadas. Este software tem uma versão gratuita e uma paga, utilizamos a gratuita que supriu as nossas necessidades neste capítulo, já que podemos capturar até dez minutos de vídeo por cada arquivo. Além de capturar vídeos, o software também captura imagens, mas não utilizamos esse recurso.

Para configurar o software, seguimos os passos:

1. Escolher na aba GERAL no item Opções, a pasta de saída para armazenar os vídeos. Escolhemos salvar na pasta de documentos com uma subpasta com o nome do software (Conforme Figura 5);

2. Clicar em VÍDEO e ativar Gravar/Parar atalho, escolhemos o atalho como a letra $\mathbf{A}$, mas qualquer outra tecla pode ser escolhida. (Conforme Figura 6);

3. Escolhemos o formato de vídeo AVI por ser facilmente reconhecido em programas de exibição de vídeo. Para as configurações técnicas do vídeo escolhemos: Xvid (VBR), Full Size, 3000fps, 80q (configurações já vindas no software). E para as configurações do áudio escolhemos: MPEG-1 L2, 48,0KHz, stereo, 192kbps (configurações já vindas no software). (Conforme Figura 6);

4. Após as configurações ajustadas, abrimos o vídeo com a legenda em português e fomos selecionando as cenas uma a uma (as que continham EI nos diálogos) e em seguida, verificamos se os vídeos estavam adequados ou se ficaram com alguma falha (foi capturar os vídeos mais de uma vez cada um, pois as imagens às vezes ficavam com o áudio atrasado em relação com as imagens). 
No processo de capturar as partes dos episódios que continham as EI, seguimos o passo a passo descrito acima e obtivemos um total de 32 cenas gravadas através deste software. A importância de se ter essas cenas se dá pela necessidade de se analisar o contexto em que as EI estão inseridas, uma vez que, ter apenas as EI não é suficiente para se fazer uma análise, pois as EI ganham sentido de acordo com a situação de uso.

Após termos apontado os caminhos metodológicos percorridos; a seguir apresentaremos a análise dos dados.

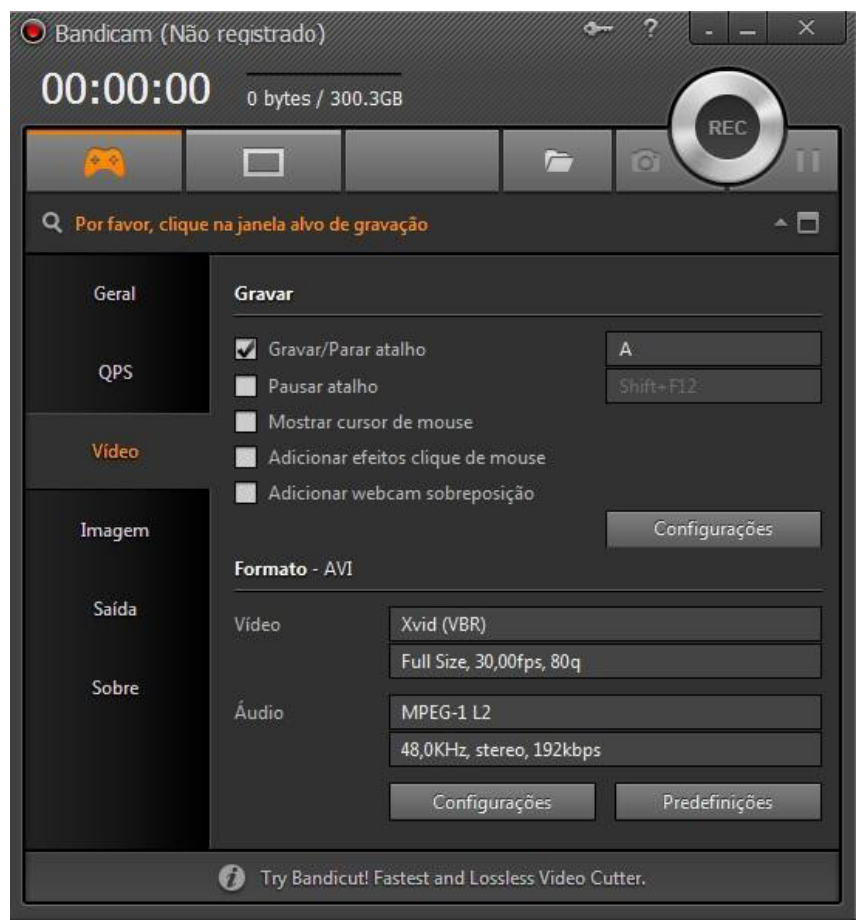

Figura 5 - Configuração do Bandicam -Geral Fonte:Bandicam. 


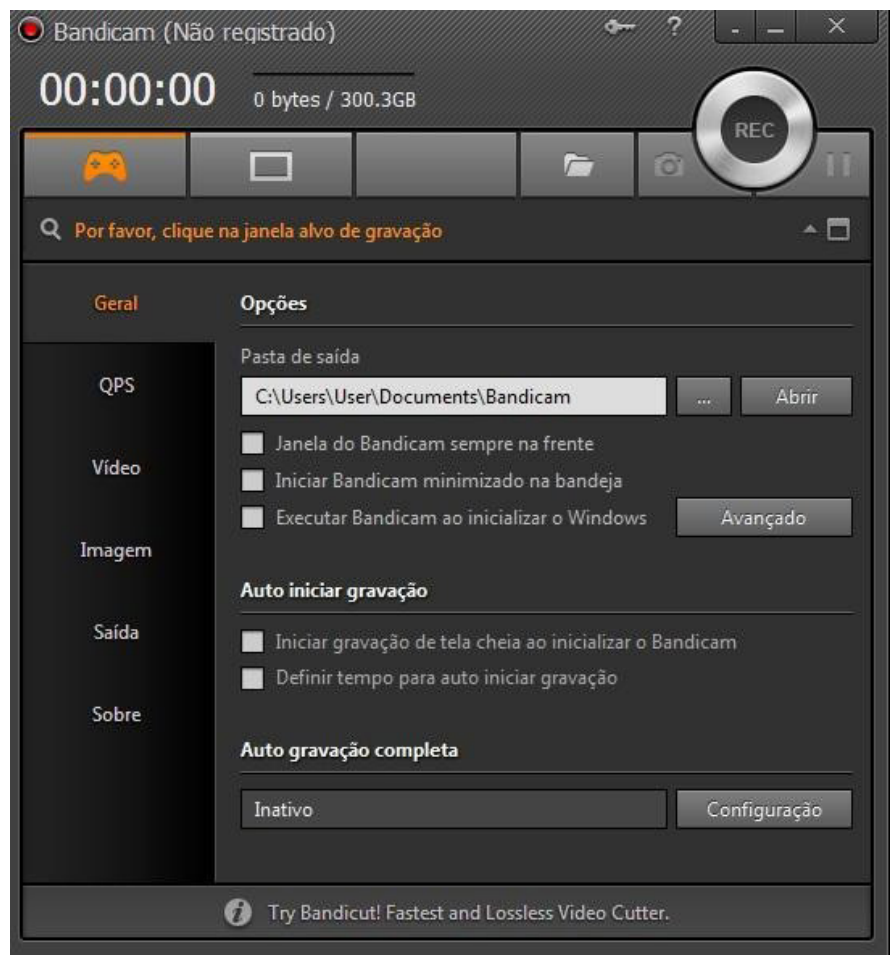

Figura 6 - Configuração do Bandicam-Video

Fonte:Bandicam.

\section{Olhar analítico sobre legendas: números e representações}

A seguir apresentamos a análise quantitativa dos dados, observando as estratégias de tradução utilizadas na tradução das EI nas legendas. 
Quantificações das El distribuídas em categorias

As EI foram organizadas segundo as categorias como apresentado abaixo:

Categoria 1:Tradução literal de EI, perdendo-se o sentido dela (04 ocorrências)

Episódio I $\rightarrow$ a) to pay your dues - pagar suas dívidas.

Episódio II $\rightarrow$ a) let their hair down - deixassem os cabelos crescerem; b) get that reference - peguei a referência; c) that ship has sailed - esse navio já partiu.

\section{Categoria 2: Tradução de uma EI por outra com o mesmo efeito (24 ocorrências)}

Episódio I $\rightarrow$ a)on the black side - meio por fora; b) on the down-low - -s escondidas; c) hands are tied - mãos estão atadas; d) at a turning point - em tempo de mudança; e) put the hells out - dê o fora; f) in one fell swoop - num piscar de olhos; g) keep it hush-hush - manter em segredo; h) found your calling - nasceu para fazer isso.

Episódio II $\rightarrow$ a) I am going for it - vou batalhar por isso; b) to tie yourself down - apertar o cinto; c) a rough ride uma viagem difícil; d) I do not give a flying fart - não dou a mínima; e) get the hell out of - dê o fora; f) hot off the presses - acabou de sair de forno; g) Hot off the presses? - Acabou de sair do forno?; h) wet your bed - você molhava sua cama; i) don't give a fart - não dá a mínima.

Episódio III $\rightarrow$ a) to move on - seguir em frente; b) making a self-serving spectacle - fazendo um espetáculo; c) the dark side - lado negro; d) chickened out - amarelei; e) treat me with kid gloves - sentir pena de mim; f) kick the crap out of - chutar a bunda; g) leave the nest - deixando o ninho. 


\section{Categoria 3: Tradução de uma EI por meio de pará- frase (30 ocorrências)}

Episódio I $\rightarrow$ a) break it down - explicar; b) you cheated on me -você me traiu; c) out of the picture - fora; d) cheat on you - trairia você; e) give it a try - tentar; f) put something together - fiz uma coisinha; g)in a pinch - em apuros; h) had each other's backs - se apoiaram; i) to step in - agirmos; j) she's falling apart - ela está desmoronando.

Episódio II $\rightarrow$ a) maximize my odds - ter todas as chances; b) on the verge of crying about - estejam chorando; c) freak me out - me apavoram; d) I would watch your tone - eu manteria o tom; e) making out - beijando; f) all hell broke loose - tudo desabou; g) hang out - ficar comigo; h) get the hell out of - sair; i) go after - acabar; j) go after - vá atrás; k) can't help não poderão evitar.

Episódio III $\rightarrow$ a) keep that out - escondo isso; b) to get us through - para passarmos; c) hard times - dificuldades; d) bummed out - chateado; e) get the hell out of - saia; f) get the hell out of - sair; g) can't take it - não consigo aguentar; h) rush me out of the door - me apressar para eu sair daqui; i) tripping me out - me incomoda.

\section{Categoria 4: Omissão da EI (01 ocorrência)}

Episódio II $\rightarrow$ a) and the Cheerios do not give a flying fart - e as Cheerios também não.

Em suma, podemos verificar que: na categoria 1 obtivemos uma ocorrência no $1^{\circ}$ episódio, três no $2^{\circ}$ episódio e nenhuma no $3^{\circ}$ episódio; na categoria 2 encontramos oito ocorrências no $1^{\circ}$ episódio, nove no $2^{\circ}$ episódio e sete no $3^{\circ}$ episódio; na categoria 3 observamos dez ocorrências no $1^{\circ}$ episódio, onze no $2^{\circ}$ episódio e nove no $3^{\circ}$ episódio; e, 
por fim, na categoria 4 há uma ocorrência apenas no $2^{\circ}$ episódio. Para que fiquem mais claros esses dados, podemos visualizá-los no gráfico 1 .

Chegamos a um total de 59 ocorrências de EI nas três legendas selecionadas, sendo 19 EI encontradas no primeiro episódio, 24 no segundo e 16 no terceiro episódio. Verificou-se que das 59 ocorrências: 4 EI foram traduzidas literalmente, perdendo-se o sentido idiomático; 24 EI foram traduzidas por outras EI com o mesmo efeito; 30 EI foram parafraseadas; e, uma EI foi omitida. Podemos ver esses dados em porcentagem no Gráfico 2.

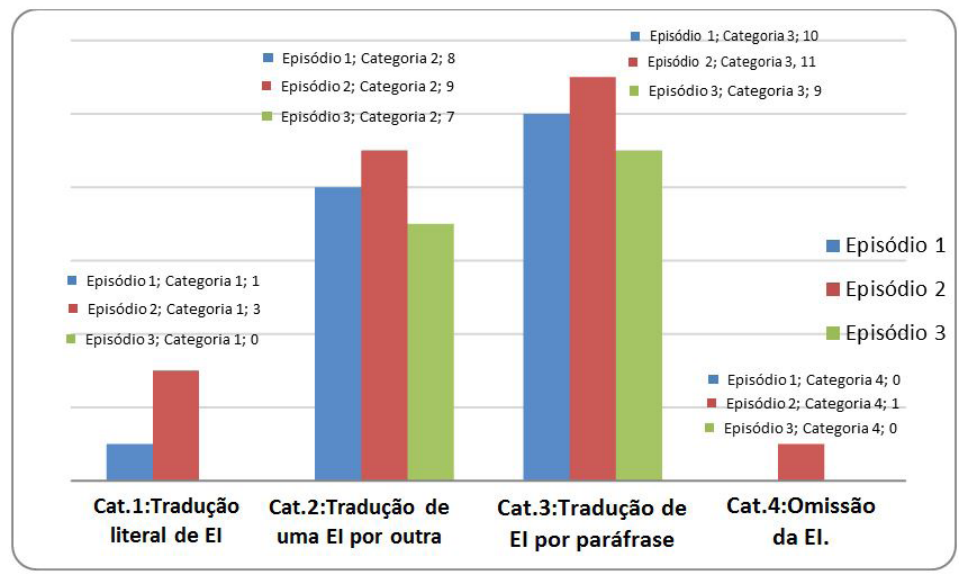

Gráfico 1 - Número de EI encontradas em cada episódio, dividido pelas quatro categorias

Fonte: Elaborado pelas autoras. 


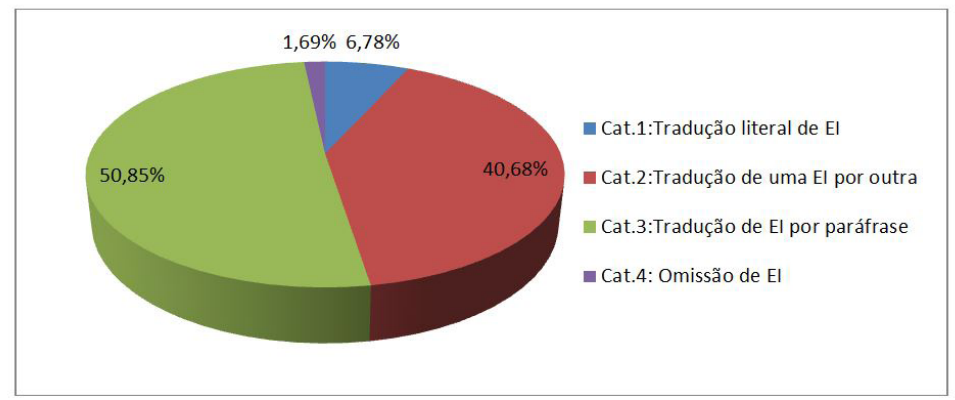

Gráfico 2 - Porcentagem das categorias

Fonte: Elaborado pelas autoras.

Com isso, constatamos que a escolha mais usada pelos tradutores foi a de parafrasear as EI (50,85\%), em seguida foi escolhido traduzir as EI por EI com o mesmo efeito da EI original (40,68\%). O sentido das EI foram perdidos em 6,78\% delas, uma vez que os tradutores usaram tradução literal, de modo que as traduções não estavam adequadas em relação ao texto original e nem fizeram sentido para a cultura brasileira. E por fim, a omissão foi apenas utilizada em uma EI (1,69\%).

Inferimos, a partir desses dados, que os tradutores conseguiram, de forma geral, traduzir as EI dos episódios escolhidos. Porém, em quatro casos a tradução literal não fez sentido com relação ao contexto, isso pode ter ocorrido porque os tradutores não conheciam o sentido que elas tinham no contexto norte-americano. $\mathrm{O}$ alto índice de ocorrências de paráfrases nos mostra que, mesmo que os tradutores não conhecessem uma EI que tivesse o mesmo efeito para o contexto brasileiro, não deixaram de encontrar um meio para transmitir a mensagem que se adequava à nossa cultura. Os 40,68\% de EI que foram traduzidas por 
outras EI nos dá a impressão de que os tradutores além de compreenderem a língua e a cultura brasileira, conhecem também a língua e a cultura norte-americana, uma vez que foram utilizadas EI que tinham o mesmo efeito para os dois lugares. E a questão de apenas uma ocorrência de omissão pode ser entendida como um ponto positivo dos tradutores, que podem ter optado por traduzirem as demais EI por julgarem serem importantes para a compreensão da mensagem e o caso da omissão foi utilizada apenas para evitar uma repetição, pois a mesma EI tinha sido utilizada anteriormente.

Analisando as estratégias utilizadas pelos tradutores, segundo a classificação de Chesterman (1997) apresentada no tópico 1.2.2 (estratégias de tradução em nível sintático, semântico e pragmático), percebemos que mais de uma estratégia pode ser usada para cada tradução de EI. Das 59 ocorrências de EI temos que: a Tradução Literal (G1) foi utilizada em 7 EI; o Deslocamento de unidade (G4) foi empregado em 41 EI; a Mudança estrutural da frase (G5) foi usada em 56 EI; a Mudança de coesão (G8) foi aplicada em uma EI; uma EI foi traduzida por meio da Sinonímia (S1); 6 EI foram traduzidas recorrendo-se à Mudança de ênfase (S7); 47 EI foi traduzidas através de Paráfrase (S8); 5 EI foram traduzidas usando Outras Mudanças Semânticas (S10), nestes casos, a mudança de sentido; o Filtro cultural (Pr1) foi aplicado em 3 EI; a Mudança de Explicitação (Pr2) foi utilizada em uma EI; e, a Mudança de Informação (Pr3) foi empregada em uma EI, neste caso a omissão da EI. Pode-se verificar esses números no Gráfico 3. 


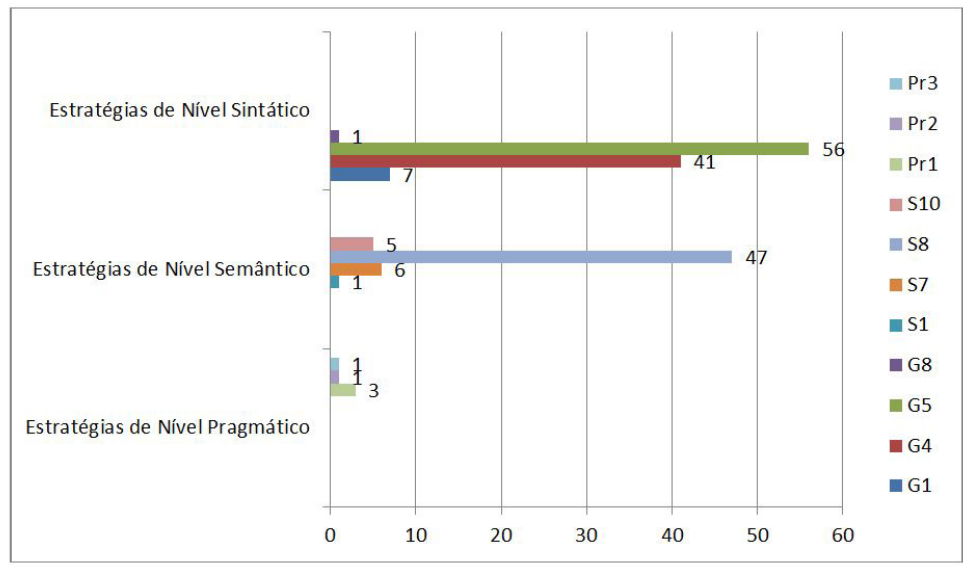

Gráfico 3 - Quantidade de cada estratégia de tradução (CHESTERMAN, 1997) utilizada nas traduções das EI separadas pelos níveis: sintático, semântico e pragmático

Fonte: Elaborado pela autora.

Ou seja, das 30 estratégias propostas por Chesterman (1997), encontramos 11 utilizadas nas traduções das EI, sendo quatro delas estratégias de nível sintático, quatro de nível semântico e três de nível pragmático.

Podemos observar que o maior número de uso foi das estratégias de nível sintático, ou seja, os tradutores optaram por manipular mais as formas. Em seguida, também em grande número, ficou o uso de estratégias semânticas que são aquelas que manipulam o significado. Por último, as estratégias de nível pragmático praticamente não foram utilizadas, o que podemos deduzir que não houve uma maior mudança do texto de partida.

Das 59 ocorrências, obtivemos 51 EI distintas, uma vez que cinco EI se repetiram ("cheat on", "get the hell out of", "give a (flying) fart", "hot off the presses" e "go after"). Destas 
EI repetidas, "cheat on" (do episódio 1) foi encontrada duas vezes e foi traduzida por meio de paráfrase (Categoria 3) pelo verbo "trair", mudando apenas o tempo verbal de cada uma; "get the hell out of" foi encontrada quatro vezes (duas vezes no episódio 2 e duas vezes no episódio 3 ) e foi traduzida por meio de paráfrase (Categoria 3) três vezes pelo verbo "sair", mudando apenas a conjugação verbal e uma vez traduzida por outra EI (Categoria 2), "dê o fora"; "give a (flying) fart" foi encontrada três vezes (no episódio 2), foi traduzida duas vezes por outra EI (Categoria 2), "não dar a mínima", mudando a pessoa e uma vez a EI foi omitida(Categoria 4). Podemos melhor observar no Quadro a seguir:

Quadro 4 - EI que se repetiram nos episódios selecionados

\begin{tabular}{|l|l|l|}
\hline EI em inglês & EI traduzida & Episódio e Categoria \\
\hline $\begin{array}{l}\text { you cheated on me } \\
\text { cheat on you }\end{array}$ & $\begin{array}{l}\text { você me traiu } \\
\text { trairia você }\end{array}$ & $\begin{array}{l}\text { Episódio 1/Categoria 3 } \\
\text { Episódio 1/Categoria 3 }\end{array}$ \\
\hline $\begin{array}{l}\text { get the hell out of } \\
\text { get the hell out of } \\
\text { get the hell out of } \\
\text { get the hell out of }\end{array}$ & $\begin{array}{l}\text { dê o fora } \\
\text { sair } \\
\text { saia } \\
\text { sair }\end{array}$ & $\begin{array}{l}\text { Episódio 2/Categoria 2 } \\
\text { Episódio 2/Categoria 3 } \\
\text { Episódio 3/Categoria 3 } \\
\text { Episódio 3/Categoria 3 }\end{array}$ \\
\hline $\begin{array}{l}\text { I do not give a flying } \\
\text { fand the Cheerios do do } \\
\text { not give a flying fart } \\
\text { don't give a fart }\end{array}$ & $\begin{array}{l}\text { não dou a mínima } \\
\text { não Cheerios também } \\
\text { não dá a mínima }\end{array}$ & Episódio 2/Categoria 2 \\
\hline $\begin{array}{l}\text { hot off the presses } \\
\text { Eot off the presses? }\end{array}$ & $\begin{array}{l}\text { acabou de sair de forno 2/Categoria 4 } \\
\text { forno? de sair do }\end{array}$ & Episódio 2/Categoria 2 \\
\hline $\begin{array}{l}\text { go after } \\
\text { go after }\end{array}$ & $\begin{array}{l}\text { Ecabódio 2/Categoria 2 } \\
\text { vá atrás }\end{array}$ & Episódio 2/Categoria 2 \\
\hline
\end{tabular}

Fonte: Elaborado pela autora. 
Observamos, ainda, que alguns personagens usam mais EI do que outros e esse uso acaba se tornando uma marca do personagem. A professora Sue é a que mais utiliza EI, ela usou 14; em seguida vem Blaine e Santana com 7 EI cada um; depois a líder de torcida Bree com 5 EI; o professor Schue utilizou 4 EI; Rachel e Kurt com 3 EI cada um; Kity, Puck, Tina, Dani e os policiais utilizaram 2 EI cada um; e por fim, Jake, Unique, Sam, Mercedes, o pai de Kurt, e Artie usaram, cada um, uma EI.

\section{Considerações finais}

O objetivo deste capítulo foi analisar a tradução de EI em legendas de três episódios do seriado Glee, da língua inglesa norte-americana para a língua portuguesa do Brasil, produzida por uma equipe de tradutores de legendas de fãs, a ser trabalhado a partir da identificação, categorização e quantificação das estratégias tradutórias utilizadas para a tradução de EI nas legendas. O objetivo foi alcançado por meio de análise quantitativa.

$\mathrm{Na}$ análise quantitativa verificamos que os tradutores conseguiram traduzir, de maneira geral, as EI dos três episódios escolhidos. Entretanto o uso da tradução literal em quatro EI não fez sentido com relação ao contexto norte-americano. A questão de apenas uma ocorrência de omissão foi um destaque positivo dos tradutores, que optaram por evitar uma repetição, já que a mesma EI foi usada antes.

A maior parte das traduções das EI foram feitas por meio de paráfrase ou por outras EI, observamos, com isso, que os tradutores além de compreenderem a língua e a cultura brasileira, são conhecedores também da língua e 
da cultura norte-americana, uma vez que foram utilizadas EI e paráfrases que tinham o mesmo efeito para as duas culturas.

A série tem ainda o seu lado da censura, uma vez que se pensa no público alvo, de jovens e a linguagem utilizada se adequa a eles, assim como também foi pensado por quem traduziu as legendas. Portanto, vemos que o seriado transmitiu essa mesma mensagem nas duas culturas aqui analisadas, o que nos leva a crer que quem a traduziu para o Brasil, através da legendagem, foi capaz de adaptar ao contexto cultural brasileiro.

Percebemos também a importância que o tradutor de legendas assume, tendo uma função social de caráter inclusivo para aquelas pessoas que, sem eles, não teriam acesso a filmes e seriados, pelos mais diversos motivos, como o lugar que moram, a falta de conhecimento da língua estrangeira, as condições financeiras, entre outros.

Sabendo da fundamental importância dos tradutores de legenda, acreditamos que esse estudo possa servir de inspiração para que sejam incluídas, em cursos de graduação de Letras ou Tradução, disciplinas sobre legendagem, já que o que se tem nos dias atuais são apenas cursos de pequena duração sobre legendagem. Inserindo disciplinas de legendagem, a formação de tradutores de legendas vai além de treinamentos com foco em aspectos da legendagem, os alunos aprenderiam também as questões teóricas da TAV que em cursos técnicos não são apresentadas.

Fazendo isso, haveria uma formação mais completa para tradutores, pois nas disciplinas de tradução para legendagem seriam desenvolvidas habilidades como: o poder de sintetizar textos, a análise textual e o domínio 
de ferramentas utilizadas na legendagem (MARTINEZ, 2007).

Por fim, a inclusão de disciplinas sobre legendagem nas universidades faria com que a profissão dos tradutores de legendas fosse mais valorizada, uma vez que a qualidade das legendas aumentaria por meio de estudos teóricos e técnicos acerca da legendagem.

\section{REFERÊNCIAS}

ALVAREZ, Maria Luisa Ortiz. Traduzir uma expressão idiomática não é quebrar galho, é descascar um abacaxi. In: SANTOS, C.A.B.; BESSA, C. R.; HATJE-FAGGION, V.; SOUSA, G. H. P. Tradução e Cultura. Rio de Janeiro: 7 Letras, 2011.

ARAÚJO, Vera Lúcia Santiago. O processo de legendagem no Brasil. Ceará: Universidade Estadual do Ceará, 2004.

BAKER, M. In Other Words. A Coursebook on Translation. Routledge, 1992.

CARVALHO, Carolina Alfaro de. A tradução para legendas: dos polissistemas à singularidade do tradutor. Dissertação de Mestrado. Rio de Janeiro: PUC-Rio, Departamento de Letras, 2005.

CHESTERMAN, Andrew. Memes of Translation: the spread ideias in translation theory. Amsterdam/ Philadelphia: John Benjamins Publishing Company, 1997. 
CINTAZ, Jorge Diaz; SÁNCHEZ, Pablo Muños. Fansubs: Audiovisual Translation in an Amateur Environment. In: Journal of Specialised Translation, Issue 06, p.3752, 2006. Disponível em: <http://www.jostrans.org/ issue06/art_diaz_munoz.pdf $>$.

CINTAZ, Jorge Diaz; ANDERMAN, Gunilla. Audiovisual Translation: Language Transfer on Screen. Palgrave MacMillan: 2009.

CINTAZ, Jorge Dias; REMAEL, Aline. Audiovisual Translation: Subtitling. UK, 2010.

FRANCO, Eliana P.C.; ARAÚJO, Vera Santiago. Questões Terminológico-Conceituais no Campo da Tradução Audiovisual (TAV). Tradução em Revista 11, 2011.

GOROVITZ, Sabine. Os labirintos da tradução: a legendagem e a construção do imaginário. Brasília: Editora UnB, 2006.

LINDE; KAY. The semiotics of subtitling.UK, 2009.

RIDD, M. D. Legendagem: corda bamba entre oral e escrito. In: ANAIS do I Encontro Nacional de Interação em Linguagem Verbal e Não-Verbal. UnB, 1995.

SILVA, Thaís Francis. Pela lente da legenda: um estudo de caso na recepção audiovisual. Brasília, 2009.

TAGNIN, Stella Esther Ortweiler. Expressões idiomáticas e convencionais. São Paulo: Ed. Ática, 1989. 
TEIXEIRA, E. As três metodologias: acadêmica, da ciência e da pesquisa. Petrópolis/RJ: Vozes, 2007.

VENUTI, L. The Scandals of translation: towards an ethics of difference. London \& New York: Routledge, 1999.

WILLIAMS, J.; CHESTERMAN, A. The Map: A beginner's guide to doing research in translation studies. St. Jerome Publishing, 2002. 


\section{EL ROL DE LA MEDIACIÓN ESTRATÉGICA EN LAS ARENAS DE INTERACCIÓN PARA LA POTENCIACIÓN DEL INTERCAMBIO LINGÜÍSTICO-CULTURAL ${ }^{1}$}

Fábio Marques de Souza (UEPB/UFPE)

Ana Luzia de Souza (UEPB/IFPB)

Angela Patricia Felipe Gama (PUC-SP)

Antes de ser profesores, fuimos y somos aprendices de idiomas $\mathrm{y}$, por consiguiente, hablantes de lenguas. Por tanto, tenemos consciencia de la dificultad que existe respecto a la adquisición de la oralidad en una lengua adicional (LA). Podemos afirmar que esta competencia es una de las más complejas o, quizás, la más difícil de adquirirse. En este sentido, Revuz (1998) expone:

Objeto de conocimiento intelectual, la lengua es también objeto de una práctica. Esa práctica es, por sí sola,

1 Agradecemos a los amigos Prof. Dr. Manoel Dias Martins y Yendrys Martínez Martínez por la revisión crítica de este texto. 
compleja. Práctica de expresión, relativamente creativa, convoca al sujeto, a su manera de relacionarse con los demás y con el mundo; una práctica corporal, pues pone en juego todo su aparato fonador. (...) El sujeto debe poner al servicio de la expresión de su yo un vaivén que requiere mucha flexibilidad psíquica entre un trabajo del cuerpo sobre los ritmos, los sonidos, las curvas de entonación, y un trabajo de análisis y de memorización de las estructuras lingüísticas. Es posible plantear la hipótesis de que muchos de los fracasos pueden ser analizados como una incapacidad de relacionar esos tres elementos: afirmación del yo, trabajo del cuerpo, dimensión cognitiva (REVUZ, 1998, p.216-217).

Tenemos consciencia de las dificultades en cuanto a la interacción oral en situaciones reales de comunicación en la lengua meta y, como profesores, somos conscientes también de nuestra función como agentes de humanización en el trabajo con el lenguaje. De esa manera, iniciaremos este texto presentando dos de los participantes que nos motivan a desarrollar nuestras prácticas e investigaciones y que, por tanto, dan significado a nuestras acciones en la enseñanza, en la investigación y en la extensión. 


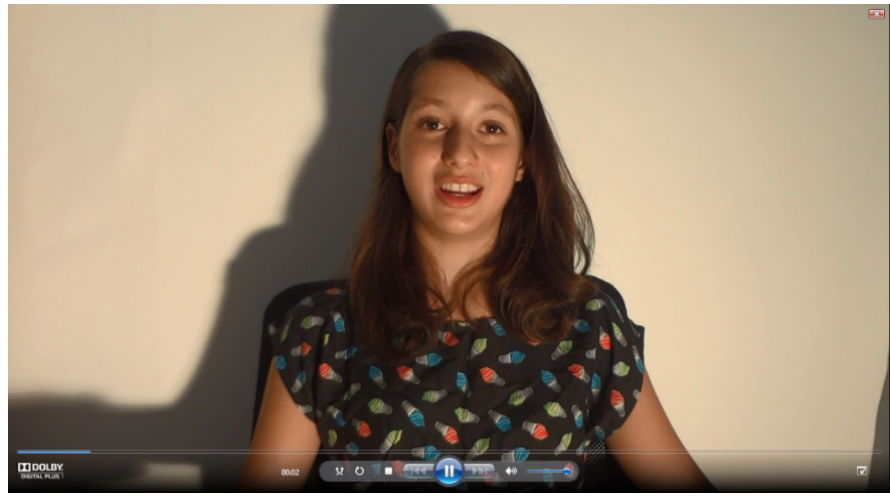

Imagen 1 - Pantalla inicial del video de presentación de Nathália, grabado en español- LA, para participación en el proyecto "INTERCULT: aprendizaje colaborativo e intercultural de lenguas vía teletándem"

Fuente: corpus reunido durante el desarrollo del proyecto "INTERCULT".

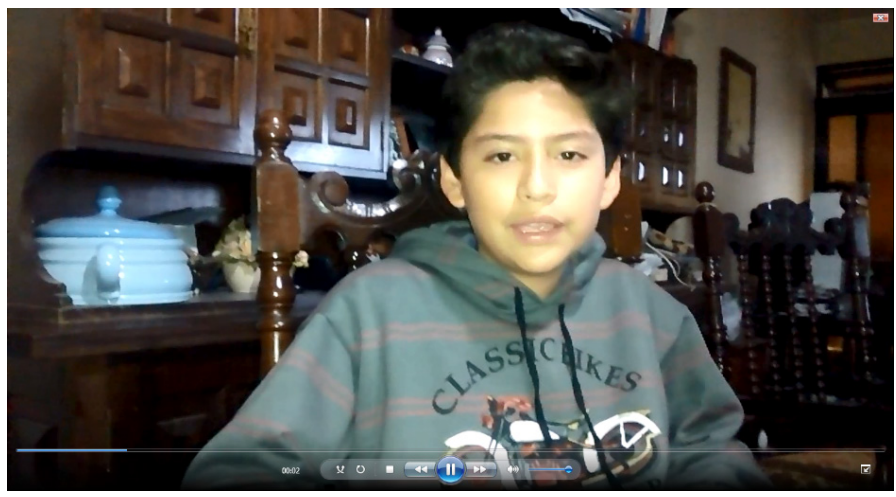

Imagen 2 - Pantalla inicial del video de Santino, grabado en portugués - LA, para participación en el proyecto "INTERCULT: aprendizaje colaborativo e intercultural de lenguas vía teletandem"

Fuente: corpus reunido durante el desarrollo del proyecto "INTERCULT". 
Nathália es brasileña, vive en el interior del Estado de Paraíba, Brasil. Tiene 12 años, cursa el 7. ${ }^{\circ}$ año de la enseñanza fundamental y estudia español. Empezó a estudiar esta LA en la escuela; participó en un curso de extensión en la UEPB y, actualmente, además de las clases regulares en el colegio, estudia en casa. Santino es argentino, vive en la Provincia de Salta, tiene la misma edad de Nathália y también es alumno de la enseñanza fundamental. Estudia portugués como LA hace 4 años, en un centro de idiomas subvencionado por el gobierno de Salta, en Argentina. Pese a que uno estudia la lengua del otro, difícilmente los dos podrían encontrarse para prácticas reales de uso de la lengua meta de cada uno, de manera que fuese promovido el avance de sus habilidades orales con el apoyo de un mediador.

El encuentro de los dos aprendientes ${ }^{2}$ fue posible a partir de la mediación con el apoyo de las Tecnologías Digitales de la Información y Comunicación (TDICS) y de profesores investigadores, realizadores del proyecto interinstitucional "INTERCULT: aprendizaje colaborativo e intercultural de lenguas vía teletándem", actividad colaborativa entre la Universidade Estadual da Paraíba, Universidade Federal de Pernambuco, Instituto Federal da Paraíba, Universidade Federal da Integração

2 Compartimos, en este texto, el término aprendiente presentado por Garcia de Stefani (2010, p.59) por ser formado del prefijo aprend - del verbo aprender y el sufijo -iente - que designa aquel que practica la acción, resaltando, de este modo, el carácter activo de aquel que aprende. 
Latino-Americana, Universidad Nacional de Rosario y del Instituto de Idiomas de Salta ${ }^{3}$ (Argentina).

A pesar de poco conocida, la práctica del teletándem es antigua, existe en muchos países, incluso en Brasil, con trabajos desarrollados por la Universidade Estadual Paulista (UNESP) y la Universidade Federal do Paraná (UFPR), por ejemplo.

La propuesta apunta a fomentar el intercambio lingüístico-cultural entre los estudiantes que tienen el portugués y el español como lenguas adicionales. De acuerdo con Souza (2015a), utilizaremos, a lo largo de este capítulo, el término "adicionales", y no "extranjeras", cuando se hace referencia a lenguas no maternas porque consideramos que el término "extranjero" tiene connotaciones que remiten a lo que es ajeno, diferente, opuesto.

Compartiendo la cita de Almeida Filho (1993) cuando dice que aprender una lengua extranjera "es crecer en una matriz de relaciones interactivas en la lengua meta que gradualmente se desextranjeriza para quien la aprende" (p.15) y considerando que la lengua, para ser aprendida/ adquirida ${ }^{4}$ necesita desextranjerizarse en un complejo continuum, juzgamos más adecuado nombrarla como lengua adicional (LA) y no extranjera.

3 Colaboración mediada por la profesora Liliana Roxana Rubín, Instituto de Idiomas de Salta, n. ${ }^{\circ}$ 7216, subvencionada por la gestión pública de educación no formal del Ministerio de Educación.

4 Los términos adquisición y aprendizaje se utilizarán, en este texto, indistintamente pese a las discusiones alrededor de esta temática, así como la dicotomía establecida por Krashen (1982). 


\section{Latinoamérica como una construcción cultural, histórica, política y no solo una construcción geográfica}

La proposición del teletándem interinstitucional, que se está desarrollando como proyecto de enseñanza, investigación y extensión, comprende lo lingüístico como elemento fundamental en el proceso de integración regional $\mathrm{y}$, de este modo, el español y el portugués son pensados como lenguas adicionales multidimensionales e interculturales de forma a promover una integración que considere Latinoamérica como construcción cultural, histórica, política y no solamente construcción geográfica (SOUZA, 2014).

De entre los diversos temas de estudio que han surgido a partir del proyecto, tenemos por objetivo investigar el rol de la mediación y su influencia en la percepción que los interactuantes tienen de su proceso de aprendizaje de lenguas y potencializar la interacción oral y cultural de los aprendientes en un contexto de no inmersión, usando el teletándem como forma de interacción. Específicamente, los objetivos son los siguientes:

- Perfeccionar la interacción oral de los interactuantes;

- Crear un corpus representativo de conversaciones mediadas por el teletándem;

- Generar datos, por medio de análisis cualitativo, de las estrategias conversacionales entre hablante nativo/ hablante no nativo;

- Crear un banco de datos para una posible elaboración de un manual de procedimientos de implantación del teletándem en escuelas y universidades. 
Convivimos con un presunto discurso de integración latinoamericana, que hace mucho tiempo permea nuestros textos oficiales, al lado de claras evidencias de imperialismo y colonización lingüística que convierten esas leyes en letras muertas.

La Constitución de 1988, en su artículo $4 .^{\circ}$, párrafo único, presenta: “ $\mathrm{La}$ República Federativa de Brasil buscará la integración económica, política, sociocultural de los pueblos de Latinoamérica, con miras a la formación de una comunidad latinoamericana de naciones". Sin embargo, nuestra historia fue marcada por un recorrido que confirma la falta de compromiso con una política que, de hecho, se haya dedicado a la construcción de una relación dialéctica entre Brasil y los países hispánicos. Desde el Tratado de Tordesillas, nosotros y nuestros vecinos hispanoamericanos vivimos de espaldas los unos a los otros. Nuestras miradas estuvieron durante muchos años volcadas hacia Europa, representada por los modelos culturales de París y/o Londres y, años más tarde, volvimos nuestra atención hacia 
Norteamérica (SOUZA, 2014, p.114, traducción nuestra). ${ }^{5}$

Según expone Souza (2009), presenciamos, en 1991, la firma del Tratado de Asunción, instrumento jurídico fundamental del Mercosur, que deja claro, en su artículo $8 .^{\circ}$, tratarse de intereses comerciales, es decir, la constitución de un mercado común entre los países miembros: “de igual forma, tal como ocurre con el Tratado de Roma (25 de marzo de 1957) que instituye la creación de la actual Unión Europea, el Tratado de Asunción no propone objetivos culturales y lingüísticos" (CHAREILLE, 2003, p.66).

Arnoux (2010) analiza las representaciones sociolingüísticas y la construcción de identidades colectivas. Esta investigadora expone que el pueblo latinoamericano tendrá que ampliar sus identidades nacionales rumbo hacia una identidad que implica la consciencia de un destino común.

5 Traducción nuestra para: A Constituição de 1988, no seu artigo 4 , parágrafo único, apresenta: "A República Federativa do Brasil buscará a integração econômica, política, social e cultural dos povos da América Latina, visando à formação de uma comunidade latino-americana de nações". Porém, nossa história foi marcada por um percurso que confirma a falta de compromisso com uma política que, de fato, tenha se dedicado à construção de uma relação dialética entre o Brasil e os países hispânicos. Desde o tratado de Tordesilhas, nós e nossos vizinhos hispano-americanos vivemos de costas uns para os outros. Nossos olhares estiveram por muitos anos voltados à Europa, representada pelos modelos culturais de Paris e/ou Londres e, anos mais tarde, voltamos nossa atenção para a América do Norte (SOUZA, 2014, p.114). 
La construcción de una identidad colectiva impone la necesidad de políticas lingüísticas plurilingües sostenidas por políticas mediáticas y escolares que permitan a los futuros ciudadanos la comprensión mutua, para que puedan expresarse en otras lenguas y que sean capaces de elaborar estrategias lingüísticas de aprendizaje.

En este sentido, lo deseable es que las políticas lingüístico-culturales contemplen diversas modalidades de bilingüismo portugués-español y la convivencia con las lenguas de los pueblos originarios. El aprendizaje de la lengua del otro cumple una función decisiva no sólo porque permite ampliar las redes comunicativas, sino también por el juego de resonancias culturales a que cada lengua está asociada.

Tanto la legislación brasileña (Ley n. ${ }^{\circ}$ 11.161/2005) como la argentina (Ley n. ${ }^{\circ} 24.468 / 2009$ ), pueden considerarse como ejemplos de respuestas a las necesidades actuales de integración regional. Sin embargo, para que tales medidas no fracasen, son necesarias la concienciación y la actuación de la población de modo que esas políticas sean implantadas y se tornen, de hecho, públicas. En esta ocasión, es importante evaluar las creencias ${ }^{6}$ asociadas a las lenguas (SOUZA, 2015).

6 Adoptaremos la perspectiva sociocultural e interpretaremos las creencias como un elemento de la cognición. De este modo, compartiremos la definición de Barcelos (2006, p.18), que corrobora el sentido adoptado para nuestros estudios: "[Las creencias son] una forma de pensar, como construcciones de la realidad, formas de ver y percibir el mundo y sus fenómenos, coconstruídas en nuestras experiencias y como resultado de un proceso de interpretación y (re) significación. Como tal, las creencias son sociales (pero también individuales), dinámicas, contextuales y paradójicas". 
Ante lo expuesto, la integración regional puede ir más allá de la pauta meramente económica y, para consolidar la integración político-cultural, es fundamental la integración lingüística, que implica la sensibilización de la población para que esta adquiera conciencia de la importancia de tal hecho para el futuro de nuestros países. En tal dirección, el proyecto "INTERCULT: aprendizaje colaborativo e intercultural de lenguas vía teletándem" presenta sus contribuciones cuando favorece el intercambio lingüístico-cultural entre brasileños aprendientes de español e hispánicos aprendientes de portugués.

\section{Del tándem al teletándem}

A partir de una consistente revisión bibliográfica, Benedetti (2010) expone que, aunque poco conocido en Brasil, el aprendizaje de lenguas en tándem surgió en Alemania a finales de los años sesenta, diseminándose en las décadas siguientes por otros países de Europa como modalidad alternativa y complementaria al aprendizaje formal de lenguas adicionales (SOUZA, 2015b).

Inicialmente, el término tándem hacía referencia a una bicicleta para dos personas que dispone de dos sillines colocados el uno detrás del otro. Con el paso del tiempo, este término pasó a ser utilizado para definir un conjunto de dos personas que poseen una actividad en común o que colaboran en algo. En el campo de la enseñanza y aprendizaje de lenguas, "el aprendizaje en tándem consiste en el intercambio de conocimiento entre individuos 
de diferentes culturas, con propósitos de aprendizaje de lenguas de modo colaborativo" (BENEDETTI, p.21) .

Esta práctica se fundamenta en la concepción sociocultural del desarrollo humano y concibe, por tanto, el aprendizaje como un proceso socialmente mediado que fomenta la asociación entre personas que desean aprender una lengua adicional y que se ponen de acuerdo en alcanzar una meta por intermedio de prácticas con hablantes proficientes en el idioma que desean aprender. En otras palabras, se puede definir el aprendizaje en tándem como un proceso en que colaboran dos personas con diferentes lenguas maternas y que se ayudan mutuamente trabajando para incrementar los conocimientos idiomáticos, culturales $\mathrm{y}$, a veces, también para intercambiar otro tipo de información relacionada, por ejemplo, a sus respectivos estudios, gustos o áreas de interés o trabajo y que puede practicarse de modo presencial $u$ otro medio de comunicación.

Son características del aprendizaje en tándem: I) abierta, puesto que no sigue un programa curricular fijo; II) intercultural, por el hecho de que implica diferentes lenguas y culturas; III) interpersonal, practicado por parejas de aprendices; IV) socialmente simétrica, involucra la alternancia de roles, pues en determinado momento se puede ser aprendiz de la lengua del compañero, y en otro, profesor del propio idioma.

7 Nuestra traducción para "a aprendizagem em tándem consiste no intercâmbio e compartilhamento de conhecimento entre indivíduos de culturas diferentes, com propósitos de aprendizagem de línguas de modo colaborativo". 
El trabajo en tándem puede ser realizado desde diferentes perspectivas:

- Presencial, designado también cara a cara. La comunicación es predominantemente oral, pero los participantes, siempre que quieran, pueden recorrer a materiales escritos y también apuntar las informaciones;

- Por correo electrónico (e-mail), conocido también por e-tándem. Considerando que los participantes en e-tándem se encuentran en sitios diferentes, es difícil seguir las mismas pautas del tándem presencial;

- Teletándem, diferente del tándem presencial y del e-tándem, porque permite una interacción completa (escrita y audio-visual) en tiempo real entre los participantes, debido a programas de comunicación gratuitos a través de internet (RAMMÉ, 2014).

Independiente de la perspectiva adoptada, se trata de una posibilidad para una comunicación auténtica en la lengua meta. En este contexto, las informaciones negociadas respecto a la cultura, la forma de vivir, entre otros elementos de determinado país, provienen de una persona concreta, con su personalidad y percepción de todo lo que está en su entorno.

Es un complemento para la clase de LA, tanto si se realiza de forma presencial como por Internet. Aprender en tándem es una práctica realizada por intermedio de comunicación auténtica con un interlocutor nativo, que sirve de modelo y que puede corregir y auxiliar a la hora de expresarse. 
En su concepción actual y en sus muchas formas (en parejas, en grupos, en e-tándem, tándem presencial, teletándem, etc) el tándem se convirtió, antes de todo, en una actividad complementaria al proceso tradicional de aprendizaje de lenguas (en el aula, principalmente), pues pone los aprendices de lengua adicional en contacto con hablantes nativos de la lengua meta, proporcionando ambientes comunicativos auténticos en que estos pueden desarrollar sus habilidades sociocognitivas, interculturales y lingüísticas de manera plena e irrestricta (RAMMÉ, 2014).

El hecho de que ambos pueden, de alguna forma, hablar la lengua del otro, les permite la ayuda recíproca mediante explicaciones, comparaciones entre las culturas o esquemas lingüísticos. Además, cuando se establece una comunicación entre personas de diferentes comunidades de lenguas y de culturas, se facilita, igualmente el aprendizaje intercultural.

El tándem, como herramienta de aprendizaje de una lengua adicional, puede encuadrarse en las más recientes teorías sociointeraccionistas de enseñanza y aprendizaje. Vygotsky y Bajtín, influenciaron fuertemente la enseñanza de lenguas adicionales, cuando situaron la cultura y el lenguaje en la constitución social del hombre y del conocimiento. Para ambos, la lengua es producto de actividades sociales, resultantes de interacciones entre interlocutores, por lo tanto, la enseñanza de lenguas no puede dejar de considerar la lengua en contexto. En consonancia, el tándem se basa en el presupuesto de que en las interacciones entre los tandenistas el conocimiento (de la lengua, de la cultura del otro) es socialmente co-construido en la interacción entre los pares por intermedio del lenguaje (RAMMÉ, 2014). 
El desarrollo de la competencia intercultural se presenta como un importante factor con apoyo tecnológico. Siempre ha formado parte del aprendizaje de la lengua, pero actualmente ha adquirido una creciente importancia.

\section{La importancia de la mediación estratégica}

Varios investigadores consensuan en que las situaciones cotidianas de enseñanza y aprendizaje componen un proceso en el que existen interacciones dinámicas entre cognición, contexto y experiencia. En efecto, los contextos social, institucional, físico, por los cuales alumnos y profesores actúan, ejercen profundo impacto en sus cogniciones. Mejor dicho, el aprendizaje puede considerarse como procesual y socialmente mediado. Un concepto central para la comprensión del pensamiento de Vygotsky respecto al funcionamiento psicológico es el concepto de mediación.

Para ampliar nuestra concepción respecto a la mediación, presentaremos algunas definiciones que colaboran con el sentido adoptado en este estudio. Gehlen \& Delizoicov (2012) argumentan que mediación "se caracteriza como un proceso de intervención de un elemento intermediario en una relación que deja de ser directa y pasa a ser mediada por tal elemento ${ }^{8 \prime}(2012$, p.61).

De forma complementaria, Vieira-Abrahão (2012) presenta este concepto como primordial en la teoría sociocultural: "Es el proceso mediante el cual los seres humanos se

8 Nuestra traducción para "pode ser caracterizada como um processo de intervenção de um elemento intermediário numa relação que deixa de ser direta e passa a ser mediada por tal elemento" (p. 61). 
valen de artefactos culturalmente construidos, de conceptos y de actividades para controlar y transformar el mundo material o su propio mundo y sus actividades sociales y mentales recíprocamente ${ }^{9 \prime \prime}(2012$, p.5).

Vygotsky (2007) expone, en su obra, que la relación del hombre con el mundo no es una relación directa, sino fundamentalmente una relación mediada. Esta mediación se realiza a través de instrumentos y de signos. La mediación por instrumentos es la relación de las personas, usando herramientas que sirven de intermediarias con los elementos del mundo. A modo de ejemplo, podríamos citar el hacha, que tiene el potencial de cortar de manera más ágil que la mano humana y los útiles que permiten el acopio de agua. Luego, estos instrumentos hacen una mediación entre la acción concreta sobre el mundo y el mundo.

El concepto vygotskyano de mediación se relaciona directamente con la cuestión de la internalización "la internalización de las actividades socialmente arraigadas e históricamente desarrolladas constituye el aspecto característico de la psicología humana; es la base del salto cualitativo de la psicología animal para la psicología humana ${ }^{10 \prime \prime}$ (VYGOTSKY, 2007, p.76).

9 Nuestra traducción para: “É o processo por meio do qual os seres humanos se utilizam de artefatos culturalmente construídos, de conceitos e de atividades para regular (ganhar controle voluntário e transformar) o mundo material ou seu próprio mundo e suas atividades sociais e mentais reciprocamente (p.5).

10 Nuestra traducción para: "a internalização das atividades socialmente enraizadas e historicamente desenvolvidas constitui o aspecto característico da psicologia humana; é a base do salto qualitativo da psicologia animal para a psicologia humana" (VYGOTSKY, 2007, p.76). 
La invención y el uso de los signos como recursos auxiliares para solucionar un determinado problema psicológico, tales como acordarse, comparar, relatar, elegir, por ejemplo, son análogos a la invención y el uso de los instrumentos, sólo que ahora, en el ámbito psicológico. Los signos son formas posteriores de mediación de carácter semiótico (simbólico), que se interponen entre el sujeto y el objeto de conocimiento. El hecho de cambiar el anillo de dedo, por ejemplo, para que uno se acuerde que tiene que llamar a alguien, es una información de carácter simbólico que está interpuesta entre la intención de hacer algo y la propia acción. Esto, todavía, es concreto, aún es visible por otros, está marcado en el mundo fuera de nosotros, sin embargo, no es de carácter instrumental, sino de naturaleza simbólica, en el sentido de que no actúa directamente sobre las cosas, pero actúa en un plan simbólico.

Los signos aparecen en otro plan, pero este, totalmente simbólico. Los elementos son puestos dentro del sistema psicológico de las personas y funcionan como mediadores semióticos. Para tanto, aparece una característica intrínsecamente humana, que es la posibilidad de representación mental; la posibilidad de transitar por un mundo que es sólo simbólico.

Cuando vemos una silla no estamos relacionándonos con ella de manera no mediada, directa. Sólo la sentimos si la tocamos y la sentimos si es de madera, de plástico, de acero etc., o si nos sentamos en ella. La miramos y vemos "silla" inmediatamente. Ella nos remite a un objeto de carácter simbólico que ya está dentro de nuestra cabeza, que es el concepto de silla, la idea de silla, la palabra silla, la imagen silla. 
Sea cual sea la forma, hay una representación de los elementos del mundo que está dentro de nosotros, que no es el mundo, sino representaciones del mundo. Por tener el ser humano esta capacidad, podemos transitar entre dimensiones de tiempo, podemos pensar en momentos pasados, anticipar momentos futuros, podemos imaginar objetos o acciones en diferentes espacios, todo por intermedio de este plan simbólico, de estos mediadores que hacen ese puente entre nuestra persona y el mundo. Gran parte de la acción del hombre en el mundo es mediada por la experiencia de otros. No es necesario vivir todo en primera mano. Esto es esencial para los procesos de crecimiento histórico, de no ser así, cada ser humano tendría que empezar todo del punto cero.

En esta ocasión, creemos que, a partir de la visión que comulgamos en este texto, el complejo proceso de enseñanza y aprendizaje puede concebirse como mediación dialógica. Luego, "cuando la enseñanza propicia oportunidades de aprendizaje en que los individuos pueden participar en actividades que les proporcionan experiencias directas en el uso de nuevas herramientas psicológicas, estas tienen el potencial para funcionar como instrumentos poderosos"11 (SOUZA, 2014, p.78).

Otro concepto fundamental para comprender los procesos de mediación e internalización es el de la zona de desarrollo próximo (ZDP). Vygotsky (2007) presenta

11 Nuestra traducción para: "quando o ensino cria oportunidades de aprendizagem em que os indivíduos podem participar em atividades que lhes proporcionam experiências diretas no uso de novas ferramentas psicológicas, essas ferramentas têm o potencial para funcionar como instrumentos poderosos (SOUZA, 2014, p.78). 
este término como "la distancia entre el nivel de desarrollo real, que suele determinarse a través de la solución independiente de problemas bajo la orientación de un adulto o en colaboración de compañeros más capaces"12 (p.97). En otras palabras, a modo de ejemplo, este concepto expone que lo que un niño puede hacer hoy con la ayuda de un adulto será lo que conseguirá hacer solo en el futuro.

Souza (2014) complementa que la ZPD puede ser definida como la diferencia entre qué puede alcanzar una persona de forma independiente y qué puede conseguir trabajando en colaboración con otras personas o con un mediador más capaz. El autor recurre a Jonhson ${ }^{13}$ (2009) y argumenta que cuando reconocemos la ZDP como:

Multidimensional y dinámica y como lugar de crecimiento potencial, debemos ofrecer a los alumnos instrumentos de mediación estratégicos, en

12 Nuestra traducción para: "a distância entre o nível de desenvolvimento real, que se costuma determinar através da solução independente de problemas, e o nível de desenvolvimento potencial, determinado através da solução de problemas sob a orientação de um adulto ou em colaboração com companheiros mais capazes" ( $p$ 97).

13 Nuestra traducción para: multidimensional e dinâmica e como lugar de crescimento potencial, devemos oferecer aos alunos instrumentos de mediação estratégicos, em vez de instrumentos fixos ou aleatórios. Isto, entretanto, é difícil de ser executado nas escolas onde os instrumentos de mediação disponibilizados para os professores tendem a ser formalizados (livros didáticos), fixos (técnicas educacionais específicas), e rotinizadas (normas escolares) (p. 20). 
lugar de instrumentos fijos o aleatorios. Eso, sin embargo, es difícil de ejecutarse en las escuelas donde los instrumentos de mediación disponibles para los profesores tienden a ser formalizados (libros de texto), fijos (técnicas educacionales específicas), y rutinarios (normas escolares) (p. 20).

De esta manera, en nuestra investigación, consideramos fundamental buscar una comprensión amplia de las TDICS y de los docentes como instrumentos de mediación para el desarrollo de la capacidad comunicativa en una perspectiva discursiva, vía diálogo y promoción de la alteridad.

\section{Algunas cuestiones metodológicas}

Apoyados en la experiencia de Souza (2014), entre los diversos caminos para el avance de la investigación científica, nos afiliamos a la investigación cualitativa de carácter etnográfico a causa de sus contribuciones para la comprensión del ámbito educativo y pedagógico, en que las relaciones humanas y las diversas variables juegan un papel muy relevante. En efecto, la investigación se vuelve compleja y demanda una metodología que contenga conceptos, instrumentos y procedimientos que describan y analicen esa realidad adecuadamente.

Buscando comprender las potencialidades y limitaciones de la investigación etnográfica en contextos de enseñanza y aprendizaje de lenguas adicionales, contamos con Cançado (1991) y, para la comprensión de la 
metodología de la investigación de creencias en el contexto de la enseñanza y aprendizaje de lenguas nos apoyamos en Barcelos (2001) y Vieira-Abrahão (2006).

El paradigma cualitativo posee una orientación sociocultural, que enfatiza los factores externos y sociales. Los fenómenos se investigan in situ, en el mismo contexto social donde ocurren. No se vale de datos numéricos de la realidad, sino que trata de interpretarla y describirla minuciosamente a través de la palabra. Tenemos como ejemplo: los apuntes de campo, los diarios, los informes basados en la observación y las entrevistas.

En este contexto, la investigación cualitativa se interesa por el significado de las acciones humanas y de la vida social en general, y está orientada a la manifestación, interpretación y comprensión de los fenómenos:

El interés de los educadores por ese método de investigación comenzó a finales de los años setenta, pues se necesitaba un estudio minucioso en el ámbito de lo cotidiano escolar. Estudiosos del área destacan que una característica importante de la investigación etnográfica es el énfasis en el proceso, en lo que está sucediendo y no en el producto o en los resultados finales (SOUZA, 2014, p. 42). ${ }^{14}$.

14 Nuestra traducción para: $\mathrm{O}$ interesse dos educadores por esse método de pesquisa começou no final dos anos 70 , pois se necessitava de um estudo que fosse minucioso no âmbito do dia a dia escolar. Pesquisadores da área destacam que uma 
Así pues, nuestra investigación busca conocer el rol de la mediación y sus posibles contribuciones en el proceso de enseñanza y aprendizaje del portugués y del español como lenguas adicionales en la interacción entre brasileños y nativos hispánicos, aprendices de portugués, vía teletándem.

\section{A Modo de Cierre}

La presente investigación se encuentra, todavía, en estadio embrionario. Sin embargo, en un contexto como el que describimos a lo largo de este trabajo, existen indicios de que las TDICS y los docentes participantes actúan como mediadores útiles e imprescindibles cuando proporcionan la interacción de los aprendientes a la distancia de forma colaborativa.

A modo de ilustración de lo que se ha visto y discutido hasta aquí, presentaremos un trecho del relato espontáneo de una participante del proyecto:

Antes de comenzar a participar con el proyecto de teletándem pensaba que el mismo iba a ser complicado de llevar a cabo, dada la distancia geográfica que existe entre alumnos y la imposibilidad de pensar el aprendizaje "cara a cara". Nunca antes había participado de una experiencia de

característica importante da pesquisa etnográfica é a ênfase no processo, naquilo que está ocorrendo e não no produto ou nos resultados finais (SOUZA, 2014, p. 42). 
este tipo. Cabe aclararse el motivo: es la primera vez que en Salta se da algo así. Sin embargo, en la medida en que se fueron dando las charlas con mis compañeros (primero con Juan y después con Janice) me di cuenta de que el interés (mutuo) por estudiar y perfeccionar una segunda lengua es lo que nos lleva a eliminar esas barreras geográficas. El potencial de las TIC nos permite estar conectados en tiempo real, realizar video llamadas, escuchar al otro y hacer que nos escuchen. Las herramientas de Internet nos permiten además hacer uso de material audiovisual (en mi caso encuentro un gran potencial en los videos, los poemas hablados, las películas, entre otros). Estas herramientas ayudan en el proceso de aprendizaje y nos permiten conocer al otro de una manera más dinámica. Por ejemplo, con Janice intercambiamos películas nacionales... Ella me sugirió una película brasilera y yo, una argentina. A través de esas producciones cinematográficas uno puede ir aprendiendo de la cultura del país vecino, puede apropiarse de las expresiones idiomáticas y observar paisajes hermosos, captados por la cámara. La barrera geográfica se hace cada vez menor al saber que hay 
intereses en común con la persona que está del otro lado de la pantalla, con las mismas ganas de aprender y de mostrar su propia cultura (Dafne, información verbal).

El fragmento presentado por la participante del proyecto señala que la creencia de que aprender lenguas adicionales no funciona a la distancia por motivos geográficos y falta de contacto "cara a cara", se destruye a lo largo del proceso y da lugar a la creencia de que, con la mediación de las TDICS, la barrera geográfica es cada vez menor, desde que haya intereses en común en la pareja para favorecer el aprendizaje.

A partir de nuestro objetivo de exponer los estudios preliminares de nuestro proyecto de investigación que mira analizar el rol de la mediación en la interacción entre aprendientes de español y portugués como lengua adicional en el contexto de las prácticas del teletándem, nuestro recorrido, en este capítulo, ha comenzado con la presentación de dos de los participantes que nos motivan a avanzar en nuestras prácticas e investigaciones y que dan sentido, por lo tanto, a nuestras acciones en la enseñanza, en la investigación y en la extensión.

A lo largo de esta exposición, presentamos también, conceptos como tándem, teletándem, mediación y, entre otros, nuestra concepción de investigación cualitativa de carácter etnográfico, que ha orientado nuestra investigación de campo.

Hasta ahora, las conclusiones no son definitivas y estamos aún en fase de recolección de datos y de análisis preliminares. No obstante, podemos destacar que tenemos, 
en relación a este proyecto, entusiásticas expectativas y esperamos que colabore para el desarrollo de aprendientes interculturalistas sensibles a los procesos discursivos vehiculados en y por el lenguaje y capaces de promover la integración latinoamericana.

\section{REFERENCIAS}

ALMEIDA FILHO, J. C. P. Dimensões comunicativas no ensino de línguas. Campinas: Pontes, 1993.

ARNOUX, E. N. Representaciones sociolingüísticas y construcción de identidades colectivas en el Mercosur. In: CELADA, M.T. et al. Lenguas en un espacio de integración: acontecimientos, acciones, representaciones. Buenos Aires: Biblos, 2010.

BARCELOS, A. M. F. Metodologia de Pesquisa das Crenças sobre Aprendizagem de Línguas: Estudo da Arte. Rev. Brasileira de Lingüística Aplicada, v.1, n.1, p.71-92, 2001.

BARCELOS, A. M. F. Cognição de professores e alunos: tendências recentes na pesquisa de crenças sobre ensino e aprendizagem de línguas. In: Barcelos, A. M. F.; VIEIRAABRAHÃO, M. H. (Orgs.) Crenças e ensino de línguas: foco no professor, no aluno e na formação de professores. Campinas: Pontes, 2006, p.15-42.

BENEDETTI, A. M. Dos princípios de tándem ao teletándem. In: BENEDETTI, A.M.; CONSOLO, D.A.; VIEIRA-ABRAHÃO, M.H. (Orgs.). Pesquisas em Ensino e Aprendizagem no Teletándem Brasil: línguas 
estrangeiras para todos. Campinas: Pontes Editores, 2010, v.1, p. 21-46.

CANÇADO, M. Procedimentos de Pesquisa Etnográfica em Sala de Aula de Língua Estrangeira: avaliação das potencialidades e limitações da metodologia. Dissertação (Mestrado em Estudos Linguísticos). Belo Horizonte: UFMG, 1991.

CHAREILLE, Samantha. Planificación lingüística y constitución de un bloque regional: El caso del Mercosur (Argentina, Brasil, Paraguay y Uruguay) y de Chile. In: Language Problems \& Language Planning, v. 27, n.1, 2003, p.63-70.

GEHLEN, S. T.; DELIZOICOV, D. A dimensão epistemológica da noção de problema na obra de Vigotski: implicações no ensino de ciências. Investigações em Ensino de Ciências, v.17, n.1, p.59-79, 2012.

JOHNSON, K. Second Language Teacher Education: a sociocultural perspective. New York: Routledge, 2009.

KRASHEN, S.D. Principles and practice in second language acquisition. N.Y.: Pergamon Press, 1982.

OLIVEIRA, M.K Vygotsky, aprendizado e desenvolvimento, um processo sócio-histórico. São Paulo: Scipione, 2006.

RAMMÉ, V. Tándem: guia para uma aprendizagem solidária. Curitiba: Valdilena Rammé, 2014. Disponible en: $<$ http://www.teletandembrasil.org/home.asp>. Accesso en: 14 de feb. 2015. 
REVUZ, C. A língua estrangeira entre o desejo de um outro lugar e o risco do exílio. In: SIGNORINI, Inês (Org.) Lingua(gem) e identidade: elementos para uma discussão no campo aplicado. Campinas: Mercado das Letras; São Paulo: Fapesp, 1998, p.213-230.

SOUZA, Fábio Marques de. Espanhol-língua estrangeira para brasileiros: políticas de difusão e formação de professores no Estado de São Paulo. Dissertação (Mestrado em Educação) - Faculdade de Filosofia e Ciências, Universidade Estadual Paulista, 2009.

SOUZA, Fábio Marques de. O cinema como mediador na (re)construção de crenças de professores de espanhol-língua estrangeira em formação inicial. Tese (Doutorado em Educação: cultura, organização e educação) - Faculdade de Educação da Universidade de São Paulo: USP, 2014.

SOUZA, F. M. A sétima arte como artefato semiótico mediador das reflexões a respeito de como de aprende uma língua adicional. Revista Hispanista (Edição em Português), 2015a.

SOUZA, F. M. Teletándem UEPB. Projeto de Extensão. Campina Grande: PROEX/UEPB, 2015b.

SOUZA, F. M. Tecnologias como mediadoras do processo de ensino-aprendizagem numa perspectiva sociocultural. Projeto de Pesquisa (Pós-doutorado em Educação Contemporânea). Caruaru: UFPE, 2015c.

GARCIA DE STEFANI, V. C. O cinema na aula de língua estrangeira: uma proposta pedagógica para o 
ensino-aprendizagem de espanhol. Dissertação (Mestrado em Linguística). São Carlos: UFSCar, 2010.

VIEIRA-ABRAHÃO, M. H. Metodologia na investigação das crenças. In: BARCELOS, A.M.F.; VIEIRA-ABRAHÃO, M. H. (Orgs.) Crenças e ensino de línguas: foco no professor, no aluno e na formação de professores. Campinas: Pontes, 2006, p.219-231.

VIEIRA-ABRAHÃO, M. H. A formação do professor de línguas estrangeiras de uma perspectiva sociocultural. Signum. Estudos de Linguagem, v.15, p. 457-480, 2012.

VYGOTSKY, L.S. A formação social da mente: o desenvolvimento dos processos psicológicos superiores. Tradução: José Cipolla Neto et al. São Paulo: Martins Fontes, 2007.

WOODS, D. Teacher cognition in language teaching: beliefs, decision-making and classroom practice. Cambridge: CUP, 1996.

WOODS, D. The social construction of beliefs in the language classroom. In: KALAJA; P; BARCELOS. A. M. F. (Ed.). Beliefs about SLA: New Research Approaches. Dordrecht: Kluwer, 2003. p. 201-229. 


\section{BLOG E PROPAGANDA VIRTUAL: uma proposta para a prática de multiletramentos na escola}

Simone Dália de Gusmão Aranha (UEPB)

Maria Morganna da Silva Castro (UEPB)

Este capítulo apresenta, em linhas gerais, uma pesquisa desenvolvida no Mestrado Profissional em Formação de Professores, da Universidade Estadual da Paraíba, que foi elaborada com vistas a atender a um dos objetivos desse curso: "formar educadores capazes de contribuir para o processo de letramento e utilização de tecnologias digitais numa perspectiva crítica, bem como contribuir para a qualidade da Educação Básica da nossa região".

Na nossa prática docente, é comum nos depararmos com depoimentos de professores insatisfeitos quanto ao processo de ensino aprendizagem da leitura e da escrita na escola. Em contrapartida, encontramos, também, alunos desestimulados devido às aulas cansativas e atividades que não os motivam a desenvolver suas habilidades comunicacionais a contento. Essa problemática gera um 
conflito constante entre o quê o professor deve ensinar e o quê o aluno precisa aprender.

Ao observar o contexto escolar e o extraescolar contemporâneo, evidenciamos crianças e jovens mergulhados em tecnologias digitais: smartphone, tablet, mp3, ipad e outros. Essas novas tecnologias invadem a escola e nós, professores, muitas vezes, a tratamos como "inimigas" por considerarmos que "atrapalham" as aulas ao desviar a atenção dos nossos alunos. Entretanto, ao se inserirem nesse mundo digital, estes se deparam com diversas possibilidades de uso da linguagem, através do contato com gêneros presentes no ambiente virtual, que podem (e devem) ser direcionados para o meio escolar.

Nesse contexto, Xavier (2005) destaca a importância da prática do letramento digital na escola, explicando que o surgimento de novas tecnologias modifica as atividades humanas e, consequentemente, o ensino. Para ele, torna-se necessário professores e estudiosos da linguagem proporem atividades que exercitem o letramento digital. Seguindo este mesmo direcionamento, Rojo (2012) apresenta a noção de multiletramentos e defende a sua importância por esta unir diversas culturas e gêneros circulantes na sociedade contemporânea. Nesta pesquisa, adotamos essa perspectiva teórico-metodológica por considerarmos ser um avanço nas discussões sobre o tema, ao se postular que a maioria das práticas de leitura e de escrita da atualidade envolve os multiletramentos.

O presente estudo, então, considera a hipótese de que o uso do blog na escola contribui para a prática de multiletramentos. Sendo assim, apresenta uma proposta didática, desenvolvida a partir de uma sequência didática, utilizando o blog como ferramenta na dinamização 
de atividades em sala de aula com o gênero propaganda virtual. A escolha do blog ocorre por este software ser bastante popular, apresenta uma interface simples, não necessitando de um conhecimento especializado para acioná-lo. Além disso, tem acesso gratuito e é muito utilizado por jornalistas, fashionistas, esportistas, políticos, publicitários, professores ou usuários "comuns" que gostam de ter a sua escrita registrada em rede.

Optamos, ainda, dar destaque a um gênero discursivo multimodal: a propaganda que habita blogs. Este gênero persuasivo, muito usado na internet, abriga uma função social de extrema importância para divulgação e vendas de produtos ou ideias através do convencimento. A todo momento, os usuários da internet são surpreendidos por propagandas criativas, ricas em recursos linguísticos, imagéticos e, por vezes, sonoros. A escolha do trabalho com a propaganda virtual em blogs também se deve ao fato de considerarmos que, ao analisar esse tipo de gênero, o aluno estará desenvolvendo a prática dos multiletramentos, o que lhe permite conhecer outras competências de leitura/produção de textos, além daquelas já conhecidas pelo uso clássico do traço do lápis no papel.

O referencial teórico da pesquisa realizada teve como base os estudos dos seguintes autores: sobre letramento e a perspectiva dos multiletramentos, Kleiman (2008); Soares (2004, 2012); Xavier (2005); Rojo (2012); Lorenzi e Pádua (2012); Araújo e Rodrigues (2005) e Brasil (2006); sobre gêneros discursivos, Bakthin (2000); Bononi (2011); Marcuschi (2007); sobre o fenômeno da multimodalidade, Dionísio e Vasconcelos (2013); sobre o blog, Komesu (2005); Seabra (2010) e Pinheiro (2013); sobre o gênero propaganda virtual, Aranha (2007, 2009 e 2012); sobre vídeo 
na sala de aula, Moran (1995). No tocante à construção do tipo de pesquisa e procedimentos metodológicos, André (2008) e Moreira \& Caleffe (2008); e a elaboração da sequência didática teve como base referencial estudos de Dolz; Noverraz; Scheneuwly (2004).

\section{Do letramento aos multiletramentos}

O letramento é um tema que há muito exige atenção de pesquisadores no campo da linguagem. De uma maneira geral, letrar é ir além da compreensão do que está escrito, é saber como e por que a palavra lida se entende em um determinado contexto social.

De acordo com Soares, o termo letramento foi utilizado pela primeira vez por Mary Kato em 1986, em seguida, por Leda Verdiane Tfouni e Ângela Kleiman. Esse vocábulo originou-se da tradução da palavra inglesa litteracy, que "designa o estado ou condição daquele que é literate, daquele que não só sabe ler e escrever, mas também faz uso competente e frequente da leitura e escrita" (SOARES, 2012, p.36).

Com a discussão sobre o termo letramento para designar uma ação mais complexa do que apenas o ato de alfabetizar, novos conceitos e ações surgem, seguindo "exigências" da sociedade que é dinâmica. As práticas de leitura e escrita acompanham as transformações ocorridas, por exemplo, as tecnologias da informação e comunicação (TIC) lançaram demandas de práticas de leitura e escrita imersas no ambiente virtual.

Em uma sociedade complexa como a atual, são muitas as formas de concebermos a noção de letramento. Lorenzi e Pádua (2012, p.37) detalham alguns tipos de letramentos 
que podem ser explorados: "novos letramentos - digital (uso das tecnologias digitais), visual (uso das imagens), sonoro (uso de sons, de áudio), informacional (busca crítica da informação)"; eles ainda explicam que os multiletramentos incorporam "a multimodalidade (linguística, visual, gestual, espacial e de áudio) e a multiplicidade de significações e contextos culturais".

Por sua vez, o letramento digital requer uma atenção especial por envolver "outras" maneiras de ler e escrever. Esse tipo de letramento direciona-se para as práticas de letramento advindas da cultura letrada digital e propõe o seu uso no ambiente virtual. De acordo com Xavier (2005), o professor atento a essa realidade deve redirecionar a sua ação pedagógica de modo que instaure, na sua sala de aula, uma aprendizagem mais dinâmica, participativa e descentralizada. O desafio de lidar com "outras" formas de linguagem contemporâneas conduz a nossa discussão à prática dos multiletramentos no Ensino Básico, considerando os benefícios que revolução tecnológica pode oferecer.

O termo multiletramentos originou-se do manifesto do Grupo de Nova Londres, de pesquisadores que direcionavam a atenção da escola aos novos letramentos da sociedade, Rojo explica que o conceito de multiletramentos é o resultado da abrangência de "dois 'multi' - a multiculturalidade, característica das sociedades globalizadas e multimodalidade dos textos por meio dos quais a multiculturalidade se comunica e informa" (2012, p.12-13), então, os multiletramentos engloba o sentido de diversidade cultural, que ela especifica como um conjunto de textos híbridos de letramentos diferentes, e a diversidade de semioses, que torna a composição dos textos mais 
complexas com múltiplas linguagens, modos, estruturas etc., proporcionadas pelas tecnologias digitais.

No tocante às características dos multiletramentos, Rojo (2012), apoiando-se em pesquisas sobre o tema, aponta um resumo das mais importantes, a saber:

[...] (a) eles são interativos; mais que isso, colaborativos; (b) eles fraturam e transgridem as relações de poder estabelecidas, em especial as relações de propriedade (das máquinas, das ferramentas, das ideias, dos textos [verbais ou não]); (c) eles são híbridos, fronteiriços, mestiços (de linguagens, modos, mídias e culturas) (ROJO, 2012, p.23).

Se antes convivíamos com textos que eram produzidos e recebidos mantendo uma relação "direta" entre locutor e interlocutor, com o uso das novas tecnologias, podemos considerar que essa performance se alterou, na medida em que o interlocutor tem a possibilidade de interferir e colaborar através de ações responsivas, seja com textos, ferramentas, interfaces ou com outros usuários. Dessa forma, o leitor torna-se mais que um mero receptor - faz escolhas e toma decisões - uma vez que são inúmeras as formas de interação que as tecnologias digitais podem proporcionar: enviar/receber e-mails, postar mensagens, comentários ou vídeos em redes sociais, conversar on-line através de chats, Outlook ou Skype, fazer compras em lojas virtuais entre outras ações. 
Mais que interação, os textos que circulam na web são construídos pela colaboração, o que consequentemente quebra o paradigma de ter o texto como um bem autoral. Se a internet e as tecnologias da informação podem trazer certas preocupações, como o não controle do registro de tantas informações publicadas ao mesmo tempo em todas as partes do mundo e por todos que têm acesso, a perspectiva dos multiletramentos nos faz observar sob uma nova ótica o que seria um "problema". Elas abrem um leque de possibilidades e trazer a tecnologias contemporâneas para a sala de aula, sem dúvida, nos faz trilhar novos caminhos e posturas necessários para que fazer pedagógico extrapole os limites dos muros da escola.

Demonstramos até aqui o reconhecimento e preocupação de pesquisadores da área com os multiletramentos mais especificamente aqueles que envolvem o uso de novas tecnologias. Mas a preocupação com essa questão não se encontra apenas no meio acadêmico, faz parte do próprio documento oficial do Ministério da Educação, que contém as diretrizes para o Ensino Médio:

[...] a escola que se pretende efetivamente inclusiva e aberta à diversidade não pode ater-se ao letramento da letra, mas deve, isso sim, abrir-se para os múltiplos letramentos, que, envolvendo uma enorme variação de mídias, constroem-se de forma multissemiótica e híbrida - por exemplo, nos hipertextos na imprensa ou na internet, por vídeos e filmes, etc (BRASIL, 2006, p.28-29). 
O trabalho com os múltiplos letramentos pressupõe, portanto, uma formação reflexiva dos alunos através do envolvimento de diversas habilidades referente à leitura e à escrita. Os alunos devem ser capazes de analisar textos sob vários aspectos, além disso, devem saber posicionar-se criticamente em relação ao que leem para que se tornem sujeitos críticos na sociedade em que vivem. Por outro lado, com uma série de letramentos para explorar em sala de aula, o professor encontra mais desafios para a sua prática, que já não era simples quando envolvia apenas textos escritos no papel.

\section{Gênero, Multimodalidade, Blog}

Bakhtin (2000, p.279) teoriza que os gêneros do discurso, também designados por outros autores como gêneros discursivos ou gêneros textuais, "são enunciados (orais ou escritos), concretos e únicos, que emanam dos integrantes duma ou doutra esfera da atividade humana", e refletem as condições e as finalidades de cada esfera. $\mathrm{O}$ autor os concebe como "tipos relativamente estáveis de enunciados", e estes, por sua vez, possuem três elementos interligados no todo do enunciado: o conteúdo temático; o estilo da linguagem (seleção dos recursos lexicais, fraseológicos e gramaticais da língua) e a construção composicional.

Ao ressaltar essa relatividade, Bakhtin demonstra cautela em categorizar os gêneros do discurso, pois ao defini-los como eventos sócio históricos, o autor considera que os gêneros se ampliam de acordo com a complexidade das esferas da sociedade, tais como: o trabalho, a política, a família, a religião etc. Nesse sentido, os gêneros se 
mostram tão flexíveis e variáveis quanto à linguagem, e, portanto, é impossível estabelecer classificações duradouras como a ótica estruturalista faz parecer possível, classificando os gêneros pelo aspecto da forma.

Para Marcuschi (2007), os gêneros textuais "são fenômenos históricos, profundamente vinculados à vida cultural e social" e, como há uma heterogeneidade de gêneros orais e escritos, é impossível listar todos, mesmo porque eles estão em constantes transformações e surgem "emparelhados a necessidades e atividades sócio-culturais, bem como na relação com inovações tecnológicas" (MARCUSCHI, 2007, p.19).

Os gêneros produzidos na era digital tornam-se, portanto, mais complexos do que aqueles que preconizam apenas a organização de frases com elementos verbais. Por isso, Dionísio e Vasconcelos (2013, p.22) atentam para a necessidade de "reorganização de nossos hábitos mentais de práticas de leituras", pois as "práticas de letramento não se restringem mais ao sistema linguístico, visto que o letramento é um processo social que permeia nossas rotinas diárias numa sociedade extremamente semiotizada", como dizem as autoras.

Sobre textos multimodais, elas esclarecem que "o termo 'texto multimodal' tem sido usado para nomear textos construídos por combinação de recursos de escrita (fonte, tipografia), som (palavras faladas, músicas), imagens (desenhos, fotos reais) gestos, movimentos, expressões faciais etc" (DIONÍSIO; VASCONCELOS, 2013, p.21).

O trabalho com a multimodalidade ainda é pouco explorado na escola, que, por vezes, prioriza a análise do texto escrito sem que se relacione o uso de outras linguagens. No blog, o fenômeno da multimodalidade se faz 
presente nos links e em outros recursos que ora se apresentam em formato de texto, ora de imagens e símbolos, além de toda interatividade permitida pelo modo hipertextual, que apresenta. Especificamente na função de "postagem", é possível criar textos multimodais, pois esta ferramenta nos permite inserir textos verbais, imagens, vídeos ou links, simultaneamente, numa mesma publicação. Assim, esta pesquisa recomenda o trabalho pedagógico com o blog, por viabilizar a exploração de vários sentidos presentes nos textos.

Seabra (2010) comenta a origem do termo blog e sua função como um diário virtual que permite a publicação de textos. Ele diz que o $b l o g$ :

[...] é a abreviação do termo em inglês Web log (diário de bordo da web), um blog é uma página publicada na internet com assuntos que tendem a ser organizados cronologicamente (como se faz em um diário). Um blog permite também que leitores, conhecidos do autor ou não, postem comentários aos textos publicados (SEABRA, 2010, p.15).

Komesu (2005, p.111) explica que a palavra blog é uma corruptela de weblog que significa "arquivo na rede". O sucesso da ferramenta de acordo com a autora se dá pela "facilidade para edição, atualização e manutenção dos textos em rede", além de congregar "múltiplas semioses" (texto, som, imagem). 
Magnabosco (2009) refere-se a blog como um gênero textual, no entanto, outros autores o concebem como "suporte", por considerar que este pode "abrigar" vários gêneros, portanto, funciona como um meio de publicação de textos.

Sobre a noção de suporte, Bononi (2011, p.57) define esse termo como "uma espécie de elemento em que o gênero se fixa e que está encarregado de pôr esse gênero em circulação"; esta definição faz o autor referir-se ao suporte como um "portador de gêneros" e acrescenta que há o "suporte físico" e o "suporte convencionado". No primeiro caso, ele explica que se identifica claramente a função de suporte, - como é o caso do outdoor-, enquanto no segundo caso "um gênero pode ser convencionado como suporte de outro gênero (ou de outros)", - e esse autor o denomina de hipergênero- , a exemplo do jornal, que é um tipo de gênero que abriga outros gêneros, a saber: notícias, anúncios, horóscopo, charges, resumos de novelas entre outros.

Nesta pesquisa, preferimos considerar o blog como um híbrido entre suporte e hipergênero. Suporte, porque utilizamos este "lugar virtual" para postar textos pesquisados ou produzidos, e hipergênero, porque, além de cumprir a função social de um gênero discursivo, ele abriga vários outros gêneros dentro de seu contexto.

Ao observarmos que o blog contém vários links, que sugerem vários caminhos em sua interface, consideramos que este se apresenta em forma de hipertexto, "uma forma híbrida, dinâmica e flexível de linguagem que dialoga com outras interfaces semióticas, adiciona e acondiciona à sua superfície formas outras de textualidade", como Xavier (2005, p.171) o define. 
Se através do blog podemos publicar uma diversidade de gêneros, ele pode se tornar uma poderosa ferramenta pedagógica para as aulas de língua portuguesa, como Lorenzi e Pádua (2012) afirmam:

O blog pode ser um espaço de leitura e escrita, proporcionando novas formas de acesso à informação, a processos cognitivos, como também às novas formas de ler e escrever, gerando novos letramentos, isto é, uma condição diferente de produção para aqueles que exercem práticas de escrita no blog e por meio dele (LORENZI; PÁDUA, 2012, p.40).

A partir desse direcionamento, os alunos podem desenvolver habilidades como: posicionar-se criticamente sobre assuntos divulgados na mídia; selecionar informações para publicação; associar temas e ideias dos textos publicados; exercitar a argumentação e a postura crítica através de posts (comentários) que serão incentivados a expressar; divulgar produções textuais feitas na escola; informar sobre acontecimentos da comunidade, promover debates, enfim, produzir textos como prática social situada. Se os alunos já utilizam o blog fora do contexto escolar, então, por que não trazer essa realidade para a escola? 


\section{Sobre propagandas em ambientes virtuais}

Os gêneros digitais incorporam mais aspectos multimodais pela própria natureza do espaço virtual, que "aposta" nesses recursos para chamar a atenção dos visitantes da web: esse é o caso da propaganda virtual.

Aranha (2009, p.43) defende que o que mais seduz em uma propaganda virtual é aspecto não verbal, e que através de uma simbologia de formas, imagens em movimento ou fotos, aliadas a elementos linguísticos, produzem um efeito de sentido espetacular, mas, para que seja bem sucedido não deve ser apenas notável, é preciso capturar a atenção do leitor e despertar o seu interesse pelo o que está sendo comercializado. A informação sobre o produto deve estar bem organizada, tanto no aspecto imagístico quanto no linguístico, pois, segundo a autora, caso isso não ocorra o leitor não se sentirá atraído a conhecer melhor o produto em evidência.

No tocante aos tipos de propaganda virtual, Aranha (2009) dá destaque às "animadas", que possuem plasticidade e interligam os elementos linguísticos, e as "interativas", que possuem links e promovem uma interação entre leitor e texto, pois, na visão da autora, a ação persuasiva da propaganda virtual se configura quando o leitor "clica" e obtém acesso a outros sites.

Para desenvolver esta pesquisa e tornar o uso pedagógico de propagandas virtuais mais interessante e atraente, ampliamos a proposta para a propaganda em formato de vídeo. Por isso, temos duas etapas, na sequência didática, que apontam o contato da turma com a propaganda virtual e com a vídeo propaganda. Moran (1995, p. 27) defende esse tipo de trabalho expondo que "o vídeo é sensorial, 
visual, linguagem falada, linguagem musical e escrita. Linguagens que interagem superpostas, interligadas, somadas, não separadas"; em outras palavras, podemos dizer que o vídeo se torna tão atrativo, que potencializa o trabalho com gêneros digitais na escola.

O trabalho de produção do gênero propaganda contendo textos, imagens e sons é viável através do Movie Maker, que é um programa de construção e edição de vídeos do Windows. Este programa possui interface simples e autoexplicativa, mas proporciona diferenciadas produções a partir de apenas alguns cliques no mouse. Nele, é possível criar filmes amadores com imagens, efeitos, trilha sonora, texto e voz. Conciliar todos esses mecanismos é um atrativo à proposta dos multiletramentos, que busca desenvolver habilidades comunicacionais variadas e não apenas o exercício da escrita tradicional.

\section{Procedimentos metodológicos da pesquisa}

A delimitação do tipo de pesquisa deve estar adequada aos seus propósitos. Considerando as peculiaridades da pesquisa em questão, é possível verificar que se trata de uma abordagem qualitativa, tendo em vista que envolve fenômenos humanos e sociais, investiga-os, e formula dados complexos e dinâmicos. De acordo com Moreira e Caleffe (2008, p.73), este tipo de pesquisa "explora as características dos indivíduos e cenários que não podem ser facilmente descritos numericamente sendo o dado frequentemente coletado pela observação, descrição e gravação", sendo assim, atende à necessidade desta pesquisa, pois envolve a apresentação de resultados da aplicação de 
uma proposta pedagógica, cujas observações e interpretações dos dados consideram o contexto de uma interação social.

A pesquisa também se configura como etnográfica, porque o pesquisador precisa utilizar vários métodos para apreensão da realidade, e, como explica André (2008, p. 19), a etnografia se preocupa com o significado das ações e dos eventos e muitos desses significados não são externados através da linguagem, mas sim através das ações, que envolvem a observação e a descrição da cultura. Contudo, André (2008, p.28) esclarece que nos estudos relacionados à área da Educação não se faz estritamente etnografia, porque algumas práticas características da etnografia são dispensáveis nessa área e o que se faz é uma "adaptação da etnografia em educação", portanto, "fazemos estudos do tipo etnográfico e não etnografia em seu sentido estrito". Na presente pesquisa, para apreendermos a "realidade" analisada, foram utilizadas estratégias relacionadas à etnografia como: aplicação de questionário, observação participante, elaboração e aplicação de sequência didática, relato de experiência e análise dos dados coletados.

Para comprovar a hipótese de que a utilização do blog na escola implica em práticas de leitura e de escrita significativas para o trabalho com os multiletramentos, aplicamos uma proposta em sala de aula, portanto, utilizamos o método da pesquisa-ação, que nos permitiu colocar em prática a teoria estudada, além de nos dar a oportunidade de interferir na realidade através de uma postura agentiva e ao mesmo tempo reflexiva. A pesquisa ação abrange um plano de ação com objetivos delineados, que visam sempre à observação com a finalidade de reflexão e mudança 
de nossa prática de sala de aula, como bem destacam Moreira e Caleffe:

A pesquisa-ação é situacional - está preocupada com o diagnóstico do problema em um contexto específico para tentar resolvê-los nesse contexto é usualmente [embora não inevitavelmente] colaborativa equipes de pesquisadores trabalham juntos no projeto; ela é participativa - os participantes da equipe tomam parte diretamente ou indiretamente na implementação da pesquisa; e ela é auto avaliativa - as modificações são continuamente avaliadas, pois o objetivo é melhorar a prática (MOREIRA; CALEFFE, 2008, p.90).

Também realizamos uma pesquisa exploratória com vistas a nos aproximar dos instrumentos da pesquisa: o blog e o gênero propaganda com suas interfaces virtuais.

Após o estudo de noções importantes como letramento digital, multiletramentos, multimodalidade e gêneros virtuais, desenvolvemos uma sequência didática, baseados em Dolz; Noverraz e Scheneuwly (2004). Esse é um procedimento comum, quando se trata de uma pesquisa que envolve ensino, e pensamos ser esta uma boa opção para sistematizar e orientar o trabalho da leitura e da escrita proposto, de maneira que se coloquem em prática as teorias estudadas para posteriormente analisar os resultados obtidos. 
Toda sequência didática, segundo esses autores do grupo de Genebra, deve apresentar a situação, em seguida, a produção inicial, a exploração de alguns módulos para que se conheçam todos os aspectos referentes ao gênero textual em estudo, e, depois, a produção final do gênero. Nesse processo, o professor desencadeia as ações mediando a situação que favorece a promoção dos alunos no que diz respeito ao domínio do gênero textual.

Assim, elaboramos uma sequência didática, que foi testada ao longo do desenvolvimento da pesquisa, utilizando o blog como instrumento pedagógico. Esta sequência foi aplicada em uma turma de $9^{\circ}$ ano do Ensino Fundamental da Escola Suzete Dias Correia, localizada no município de Massaranduba, no Estado da Paraíba. Nesta turma, composta por 26 alunos com faixa etária de em média 14 anos, ministrávamos aulas de língua portuguesa.

No intuito de caracterizar os participantes da pesquisa, incluímos na etapa inicial da sequência didática a aplicação de um questionário, com vistas a conhecer o perfil dos alunos e a sua proximidade com o mundo virtual. Foram feitas também observações documentadas em um diário, em gravações, em fotos e, principalmente, nas produções textuais dos alunos registradas no blog.

As aulas foram ministradas no laboratório de informática da escola, locus da pesquisa, que contava com 25 computadores, desses, aproximadamente 15 tinham acesso à internet. O laboratório ainda dispunha de um computador para a professora-pesquisadora com uma TV de 32 polegadas e uma tela para apresentação com data show ou multimídia.

Cada etapa para aplicação da sequência aconteceu em duas aulas seguidas, intercaladas por uma aula, pois a 
carga horária semanal era de cinco aulas de 45 minutos. Assim, totalizamos aproximadamente um mês e meio de aula para conclusão da sequência, mais precisamente 19 encontros.

O tema "drogas", escolhido para produção de uma propaganda a ser postada no blog criado pela turma, se deu pelo contexto social dos participantes da pesquisa, adolescentes de uma pequena cidade de interior que conheciam usuários de drogas, ou já foram abordados para o uso. Ao se informarem mais sobre o tema, os alunos puseram em prática um trabalho social, porque, além de se autoconscientizá-los, de maneira indireta, foi feito um trabalho educativo de prevenção contra drogas. No final da sequência didática, confirmamos a hipótese de que o uso do blog como ferramenta no processo de ensino-aprendizagem contribuiu para a prática dos multiletramentos na escola pesquisada.

Vejamos, abaixo, doze etapas da sequência didática (elaborada e testada ao longo da pesquisa), que foram escolhidas como as mais significativas, dentre outras, para a apresentação neste artigo.

SEQUENNCIA DIDÁTICA: TRABALHANDO A

LEITURA/ESCRITA A PARTIR DE

PROPAGANDAS VIRTUAIS EM BLOGS

\section{Etapa 1}

Objetivo: Conhecer o nível de letramento digital dos alunos participantes da pesquisa.

\section{Procedimentos:}

$1^{0}$ momento: Explicação do objetivo do questionário.

$2^{\circ}$ momento: Aplicação do questionário. 


\section{Etapa 2}

Objetivo: Criar conta no G-mail.

\section{Procedimentos:}

$1^{\circ}$ momento: A professora explicou como criar um endereço eletrônico (e-mail) na web;

$2^{\circ}$ momento: Os alunos visitaram o site do G-mail (www. gmail.com) e seguiram os passos indicados para a criação de suas contas de e-mail;

$3^{\circ}$ momento: Os alunos construíram o perfil dos e-mails, adicionando fotos e outras informações pessoais;

$4^{\circ}$ momento: Os alunos enviaram $e$-mails para os demais colegas de turma. Depois, todos acessaram as suas contas e passaram a responder as mensagens recebidas.

\section{Etapa 3}

Objetivo: Conhecer o blog e suas características gerais.

\section{Procedimentos:}

$\mathbf{1}^{\mathbf{0}}$ momento: A professora apresentou o conceito de blog, a sua função social e as suas características;

$2^{\mathbf{0}}$ momento: Os alunos "visitaram" blogs com temas de interesse dos alunos como moda, fofoca, futebol e carros. Com a orientação da professora, conheceram links e ícones presentes nos blogs, assim, observaram que "caminhos" esses links podiam levar a partir do clicar do mouse; $3^{\mathrm{o}}$ momento: A professora solicitou uma atividade extraclasse: os alunos deviam "visitar" alguns blogs para comentá-los na aula seguinte.

\section{Etapa 4}

Objetivo: Ensinar a criar um blog.

\section{Procedimentos:}

$\mathbf{1}^{\circ}$ momento: Seguindo os encaminhamentos da aula anterior, os alunos comentaram os blogs visitados; 
$2^{\circ}$ momento: A professora apresentou os passos que devem ser seguidos para a criação de um blog. Os alunos assistiram a vídeos com tutoriais de criação de blogs;

$3^{\circ}$ momento: A professora apresentou o processo de criação e personalização do blog da turma;

$4^{\circ}$ momento: Este momento foi reservado para adição dos colaboradores do blog. Os alunos listaram seus e-mails e a professora os inseriu no blog.

\section{Etapa 5}

Objetivo: Ensinar a executar atividades de colaboração no blog.

\section{Procedimentos:}

$1^{\circ}$ momento: Os alunos acessaram suas contas de $e$-mail e aceitaram o convite de colaboração no blog, que foi enviado pela professora na aula anterior;

$2^{\circ}$ momento: Com a mediação da professora, os alunos conheceram as ferramentas de postagem disponibilizadas no blog da turma;

$3^{\circ}$ momento: Em seguida, a professora orientou a postagem de textos e imagens no blog. Foi sugerido, aos alunos, postarem mensagens de "boas-vindas".

\section{Etapa 6}

Objetivo: Orientar os alunos para a edição dos seus perfis de apresentação no blog.

\section{Procedimentos:}

$1^{\circ}$ momento: A professora explicou como os alunos deviam editar os seus perfis no blog da turma;

$2^{\circ}$ momento: Os alunos tiveram espaço para editar seus perfis, acrescentando informações que consideraram pertinentes para sua apresentação pessoal. 


\section{Etapa 7}

Objetivo: Conhecer as especificidades da propaganda em ambientes virtuais, destacando-a como um gênero multimodal.

\section{Procedimentos:}

$1^{\circ}$ momento: A professora apresentou uma propaganda virtual, publicada em um site da internet, e depois a analisou, juntamente com os alunos, enfocando as características principais desse gênero multimodal;

$2^{\circ}$ momento: Os alunos pesquisaram sobre a conceituação do gênero: o conteúdo foi selecionado, publicado e comentado no blog pelos próprios alunos.

\section{Etapa 8}

Objetivo: Analisar uma propaganda virtual, considerando tema, características, e outros elementos singulares ao gênero em estudo.

\section{Procedimentos:}

$1^{\circ}$ momento: A professora postou, no blog da turma, uma propaganda coletada em um site da web;

$2^{\circ}$ momento: A professora apresentou o conceito de multimodalidade e destacou aspectos multimodais presentes na propaganda publicada;

$3^{\circ}$ momento: Os alunos responderam a uma atividade, que foi postada previamente pela professora no blog. Em seguida, foram discutidos os comentários publicados pelos alunos.

\section{Etapa 9}

Conteúdo: Selecionando e postando propagandas virtuais. Objetivo: Desenvolver habilidades de pesquisa, postagem e compreensão da propaganda virtual. 


\section{Procedimentos:}

$1^{\circ}$ momento: Os alunos pesquisaram sites, coletaram, selecionaram e postaram novas propagandas no blog da turma; $2^{\circ}$ momento: Os alunos discutiram as propagandas postadas. O professor também fez comentários, instigando a compreensão dos alunos a respeito desse gênero discursivo.

\section{Etapa 10}

Conteúdo: Análise e produção de uma propaganda virtual.

Objetivo: Analisar e produzir uma propaganda no blog da turma.

\section{Procedimentos:}

$1^{\circ}$ momento: A professora selecionou previamente uma propaganda coletada na aula anterior e postou no blog outra atividade, solicitando à turma a produção de uma propaganda virtual;

$2^{\circ}$ momento: A professora mediou a produção das propagandas pelos alunos. As propagandas foram feitas a partir da "colagem" de desenhos feitos no computador e de imagens coletadas na internet;

$3^{\circ}$ momento: As propagandas foram publicadas no blog da turma.

\section{Etapa 11}

Conteúdo: Conhecendo vídeo propagandas.

Objetivo: Conhecer propagandas virtuais no formato de vídeo.

\section{Procedimentos:}

$1^{\circ}$ momento: A professora postou uma propaganda no formato de vídeo para apresentar as características desse gênero discursivo; 
$2^{\circ}$ momento: Os alunos comentaram, no blog, a propaganda em estudo, comparando a propaganda virtual com a propaganda no formato vídeo.

\section{Etapa 12}

Conteúdo: Buscando, selecionando e compreendendo vídeo propagandas.

Objetivo: Desenvolver habilidades de pesquisa, postagem e compreensão de propagandas em formato de vídeo. Procedimentos:

$1^{\circ}$ momento: A professora indicou sites para coleta de vídeo propagandas e mostrou como os alunos deviam criar e publicar, no blog da turma, esse tipo de propaganda; $2^{\circ}$ momento: Os alunos tiveram oportunidade de pesquisarem, selecionarem e postarem vídeo propagandas no blog;

$3^{\circ}$ momento: Após os alunos postarem comentários sobre as propagandas publicadas, a professora orientou uma discussão, enaltecendo a contribuição dos aspectos multimodais para o ensino de leitura/escrita na atualidade.

Após a apresentação dessas etapas, seguiremos, agora, com um breve relato da aplicação da proposta, no intuito de discorrermos sobre como se deu o trabalho e a apreciação dos resultados.

Inicialmente, aplicamos e analisamos os questionários, pelos quais foi possível conhecer o nível de letramento digital dos alunos. Depois, no laboratório, apresentamos alguns blogs e criamos, juntos, um blog da turma. Nessa ocasião, observamos que na transposição dos textos escritos para a digitação no blog os alunos conseguiram identificar erros ortográficos e de concordância gramatical, pela 
sinalização do corretor automático do Windows Word. Isso fez com que os alunos se interessassem pela grafia gramatical correta da palavra digitada, permitindo-lhes que desenvolvessem o aprimoramento da escrita formal no blog.

Ao longo dessas etapas, os alunos também tiveram a oportunidade de compreender que a multimodalidade é a utilização simultânea de várias formas de linguagem. Quando apresentamos propagandas virtuais, eles logo reconheceram que se tratava de um gênero multimodal, porque, além de apresentar texto verbal escrito, as propagandas utilizavam imagens, sons e outros recursos semióticos.

Ao apresentar as ferramentas disponíveis no blog da turma e solicitar que os alunos selecionassem propagandas em formato de vídeo, diretamente do site You Tube, eles desenvolveram habilidades de pesquisa e seleção de conteúdos da web, o que constitui também uma prática multiletrada. Essa atividade fez com que os alunos relacionassem imagens, palavras, músicas, sons, movimentos e produzissem sentidos, contando com essa mistura de linguagens.

A criação de um espaço coletivo - o blog - deu a oportunidade de uma maior divulgação das produções textuais dos alunos, ampliando-se o número de leitores pelo ambiente virtual, além de favorecer o diálogo entre os colegas de turma através dos comentários no blog. De fato, esse trabalho com o blog e com as propagandas virtuais, pelo envolvimento dos sujeitos participantes, impulsionou a construção do conhecimento de forma interativa e lúdica. 


\section{Considerações finais}

Nesta pesquisa, buscamos relacionar o "mundo" virtual com a "realidade" escolar, fazendo com que os alunos exercitassem habilidades de leitura e escrita, através da utilização de um blog construído pela e para a turma.

No que diz respeito às habilidades referentes aos multiletramentos, os alunos tiveram acesso às informações sobre uso de novas tecnologias na sala de aula e foi desenvolvido um trabalho orientado em conformidade com as demandas sociais atuais, a partir de gêneros discursivos multimodais. A construção do blog da turma favoreceu o desenvolvimento de práticas multiletradas, porque, para utilizá-lo, os alunos tiveram que ler e escrever de forma distinta da habitual. Esta vivência serviu para que eles percebessem que no ambiente virtual é possível aliar, simultaneamente, diversas semioses, tais como figuras estáticas e em movimentos, textos, vídeos, sons, cores, músicas e uma diversidade de gêneros discursivos.

Nesse contexto, o blog demonstrou a sua importante função de suporte de gêneros. $\mathrm{O}$ fato dos alunos terem feito uso, sem dificuldades, da interface do blog, pesquisando, selecionando e postando informações, revela um avanço na forma de se trabalhar a leitura e a produção de textos, comprovando que este software pode ser uma estratégia muito produtiva para a prática dos multiletramentos no espaço escolar.

Em suma, acreditamos que esta proposta permite aos alunos aliar, de forma positiva, as suas vivências extraescolares - o uso de tecnologias digitais - com o ensino/ aprendizagem da leitura e da produção de textos. Portanto, esta proposta acompanha os avanços do nosso tempo e é 
importante expandir contribuições desta natureza para outros professores da Educação Básica.

\section{REFERÊNCIAS}

ANDRÉ, Marli. Etnografia da prática escolar. 14. ed. Campinas: Papirus, 2008.

ARANHA, Simone Dália de Gusmão. Hipertexto, tempo e espaço: que peculiaridades essas noções assumem na era virtual?. In: ASSIS, D. L; ARANHA, S.D. de G. (Org.). A Língua e seu funcionamento: entre o texto e o discurso. João Pessoa: Ideia, 2012.

. Hiperbanner: quem resiste a essa propaganda virtu(re)al?. In: ARANHA, S. D. G.; PEREIRA, T. M. A.; LEANDRO, M. L. L. (Org.) Gêneros e linguagens: diálogos abertos. João Pessoa: Editora Universitária UFPB, 2009.

. Os enunciados interrogativos no hiperbanner: uma abordagem semântico-discursiva. (Tese de Doutorado). João Pessoa: Universidade Federal da Paraíba, 2007.

ARAÚJO, Júlio César; RODRIGUES, Bernadete Biasi (orgs). Interação na Internet: novas formas de usar a linguagem. Rio de Janeiro: Lucerna, 2005.

BAKHTIN, M. M. Estética da criação verbal. 3. ed. São Paulo: Martins Fontes, 2000. 
BRASIL. Secretaria de Educação Básica. Orientações curriculares para o ensino médio: linguagens, códigos e suas tecnologias. Brasília: Ministério da Educação, 2006.

BONONI, Aldair. Os gêneros do jornal: questões de pesquisa e ensino. In: KARWOSKI, K. M.; GAYDECZKA, B. BRITO, K. S. (orgs.). Gêneros textuais: reflexões e ensino. Palmas e União da Vitória, PR: Kaygangue, 2011.

DIONISIO, Ângela Paiva; VASCONCELOS, Leila Janot de. Multimodalidade, Gênero textual e Leitura. In: BUNZEN, Clécio; MENDONÇA, Márcia (org.). Múltiplas linguagens para o Ensino Médio. São Paulo: Parábola Editorial, 2013.

DOLZ, J.; NOVERRAZ, M.;SCHENEUWLY, B. Sequências didáticas para o oral e para o escrito: apresentação de um procedimento. In: SHENEUWLY, B.; DOLZ, J. Gêneros orais e escritos na escola. Tradução e organização Roxane Rojo e Glais Sales Cordeiro. Campinas, SP: Mercado de Letras, 2004.

KLEIMAN, Ângela B. Os estudos de letramento e a formação do professor de língua materna. In: Linguagem em (Dis)curso - LemD, v.8, n.3, set/dez. p. 487 - 517. 2008.

KOMESU, Fabiana. Blogs e as práticas de escrita sobre si na internet. In: Gêneros Textuais: definição e funcionalidade. In: DIONÍSIO, A. Paiva; MACHADO, A. Raquel. BEZERRA, Maria Auxiliadora (org.). Gêneros Textuais e Ensino. Rio de Janeiro: Lucerna, 2002. 
LORENZI, Gislaine Cristina Correr; PÁDUA, Tainá-Rekã Wanderley de. Blog nos anos iniciais do fundamental I: a reconstrução de sentido de um clássico infantil. In: ROJO, Roxane; MOURA, Eduardo (org.). Multiletramentos na escola. São Paulo: Parábola Editorial, 2012.

MARCUSCHI. Luiz Antônio. Gêneros textuais: definição e funcionalidade. In: DIONÍSIO, A. Paiva; MACHADO, A. Raquel. BEZERRA, Maria Auxiliadora (Org.). Gêneros textuais e ensino. Rio de Janeiro: Lucerna, 2007.

MORAN, J. M. O vídeo na sala de aula. Comunicação e educação. São Paulo, v.1, n.2, Jan./abr., 1995.

MOREIRA, Herivelto; CALEFFE, Luiz Gonzaga. Metodologia da pesquisa para professor pesquisador. 2.ed. Rio de Janeiro: Lamparina, 2008.

PINHEIRO, Najara Ferrari. Para além da escola: o blog como ferramenta de ensino-aprendizagem. In: BUNZEN, Clécio; MENDONÇA, Márcia (orgs.). Múltiplas linguagens para o ensino médio. São Paulo: Parábola Editorial, 2013.

ROJO, Roxane. Pedagogia dos multiletramentos: diversidade cultural e de linguagens na escola. In: ROJO, Roxane; MOURA, Eduardo. Multiletramentos na escola. São Paulo: Parábola Editorial, 2012.

SEABRA, Carlos. Tecnologias na escola: como explorar o potencial das tecnologias de informação e comunicação na aprendizagem. Porto Alegre: Telos Empreendimentos Culturais, 2010. 
SOARES, Magda Becker. Letramento e alfabetização: as muitas facetas. Rev. Bras. Educ. n.25. Rio de Janeiro, Jan/ Abr. 2004.

. Letramento: um tema em três gêneros. 3. ed. Belo Horizonte: Autêntica Editora, 2012.

XAVIER, Antônio Carlos. Leitura, texto e hipertexto. In: MARCUSCHI, Luiz Antônio; ___ _. (org.). Hipertexto e gêneros digitais: novas formas de construção do sentido. 2. ed. Rio de Janeiro: Lucerna, 2005. 


\title{
OS DESAFIOS DE EDUCAR PARA O NOVO CONTEXTO DE LEITURA, LINGUAGENS E PRODUÇÃO DA INFORMAÇÃO
}

\author{
Lígia Beatriz Carvalho de Almeida (UFCG) \\ Mariana Pícaro Cerigatto (UNESP)
}

\section{Um novo ambiente de linguagens e comunicação}

Após passarmos por fases históricas em que a linguagem oral e escrita foram predominantes em nossa sociedade, na atualidade, a atenção volta-se para a terceira "era" da linguagem, a linguagem digital, com a qual se tem mais contato. Ela é baseada em códigos binários, englobando aspectos da oralidade e da escrita em novos contextos. Em meio a isso, destaca-se, neste texto, a importância de o educador refletir sobre os novos perfis de leitores, sobre suas habilidades diante de novos textos e também as habilidades dos novos produtores de informação, que traz como consequência o pensar novos horizontes e novas perspectivas para a alfabetização necessária ao longo da vida. 
O ponto de partida desta discussão é o necessário entendimento sobre o papel transformador da tecnologia digital na formação de novos leitores e produtores. De acordo com Kenski (2007), ela

[...] rompe as formas narrativas circulares e repetidas da oralidade e com o encaminhamento contínuo e sequencial da escrita, e se apresenta como um novo fenômeno descontínuo, fragmentado e, ao mesmo tempo, dinâmico, aberto e veloz. Deixa de lado a estrutura serial e hierárquica da articulação dos conhecimentos e se abre para o estabelecimento de novas relações entre conteúdos, espaços, tempos e pessoas diferentes (KENSKI, 2007, p.31).

A base da linguagem digital é o hipertexto, "sequências em camadas de documentos interligados, que funcionam como páginas sem numeração e trazem informações variadas sobre determinados assuntos" (KENSKI, 2007, p.32). As misturas de linguagens e mídias (sons, vídeos) formam a hipermídia.

A reconfiguram formas de ler e acessar informações, e a facilidade de navegação, hipermídia e o hipertexto manipulação e liberdade de estrutura, são estímulos para a participação, interação. O poder de seletividade, de decidir o caminho da leitura é bem maior, a "exploração" da realidade informacional se torna mais acessível por meio dos vários recursos disponíveis. 
É no hipertexto que circulam os diversos conteúdos e fontes de informação; é preciso ainda mencionar os novos perfis de leitores e a relação que têm com esses novos conteúdos. O leitor da geração "Y" já não lê da mesma forma que o leitor de gerações antigas, e também diversificou bastante suas fontes de informação por causa das mais variadas possibilidades de produção de conteúdo, agora descentralizada das grandes empresas e veículos de comunicação.

Hoje a biblioteca não é fonte exclusiva de saber e informação, nem a escola o é. Um simples "meme" ${ }^{1}$ na Internet, um vídeo de um canal de um blogueiro no YouTube, um artigo ou notícia escrito em um blog independente de jornalismo são fontes de informação mais acessadas e consumidas pelas novas gerações.

O cenário de linguagens híbridas, que caracteriza o referido contexto, nasce diante o ciberespaço. As matrizes da linguagem (SANTAELLA, 2001) ajudam a compreender o fenômeno da linguagem híbrida no hipertexto. A essa expansão de signos e de linguagens no ciberespaço podemos chamar de "multiplicidade semiótica" (ABREU; MONTEIRO, 2010).

Apesar da evolução de uma diversidade de meios de comunicação, ainda diante da convergência tecnológica e de muitos estudiosos ressaltarem que para cada meio produtor de sentidos existe uma linguagem especial, Santaella (2001) argumenta, recorrendo a Peirce, que só existem três matrizes lógicas da linguagem e pensamento, "que se entrecruzam no estado da comunicação atual,

1 A expressão meme de Internet é usada para descrever um conceito de imagem, vídeo e/ou relacionados ao humor, que se espalha via Internet, conforme Dawkins (1989). 
formando a hipermídia, linguagem não-linear, não-analógica, assentada sobre o hipertexto e podendo estocar informação com mais facilidade" (REGIS, 2002, p.243).

Fazendo isso, segundo Santaella (2001), o propósito não é rotular, mas mapear as possibilidades do pensamento e do conhecimento, através das matrizes que fazem um intermediário entre os conceitos peirceanos e as linguagens manifestas, assim subsidiando a leitura de processos concretos de signos: uma música, uma poesia, um longa metragem, um programa de televisão, e todas as suas misturas que estão sujeitas a ocorrer na hipermídia.

A teoria das matrizes institui as vertentes sonora, visual e verbal, que abrangem a variedade e multiplicidade das formas de linguagens. A partir dessas matrizes instituídas com bases na tradição peirceana e na fenomenologia, todas as combinações e misturas são possíveis, segundo a autora.

Assim, as matrizes da linguagem e pensamento - a sonora, a visual e a verbal - há a correspondência com cada uma das categorias fenomenológicas e da classificação dos signos. De acordo com Santaella (2001), e agora relacionando as matrizes com os tipos de signo, a matriz sonora está para a primeiridade e se relaciona ao ícone; a matriz visual está para a secundidade e é uma questão do índice, já a matriz verbal está para a terceiridade e se refere ao símbolo. Três alicerces classificatórios foram demarcados: o eixo da sintaxe está para a matriz sonora, o eixo da forma aponta para a matriz visual e o eixo do discurso se norteia pela matriz verbal.

Essa caracterização das linguagens em três matrizes (sonora, visual e verbal) fornece subsídio para melhor apreciar e observar de maneira mais ampla e menos limitada as possibilidades de materialização do pensamento 
humano nos novos meios de informação e comunicação e as complexas linguagens, que o aparecimento da hipermídia impõe. Para Regis (2002), Santaella fornece ferramentas e fundamentação peirceana para melhor explorar o campo da linguagem, no atual contexto de produção cultural.

Após classificar as matrizes, Santaella afirma que "as matrizes não são puras. Não há linguagens puras. Apenas a sonoridade alcançaria um certo grau de pureza se o ouvido não fosse tátil e se não se ouvisse com o corpo todo" (SANTAELLA, 2001, p. 371).

Por trás da aparente diversidade dos processos de signos, sistemas de linguagens e mídias nos quais os signos se encarnam e através dos quais circulam, só há três matrizes da linguagem e pensamento. Toda a profusão diferenciada de signos com que convivemos a cada dia, hora e instante de nossa vida, não é senão fruto de misturas sem fim e combinações imprevistas de um número finito de modalidades [...] (SANTAELLA, 2001, p. 411).

Ao sustentar estes argumentos, podemos considerar que a hipermídia abriga uma mistura de linguagens, que geram desafios semióticos de interpretação e significação. Pois, segundo Santaella:

Toda nova linguagem traz consigo novos modos de pensar, agir, sentir. Brotando da convergência 
fenomenológica de todas as linguagens, a hipermídia significa uma síntese inaudita das matrizes da linguagem e pensamento sonoro, visual e verbal com todos os seus desdobramentos e misturas possíveis. Nela estão germinando formas de pensamento heterogêneas mas, ao mesmo tempo, semioticamente convergentes e não-lineares, cujas implicações mentais e existenciais, tanto para o indivíduo quanto para a sociedade, estando apenas começando a apalpar (SANTAELLA, 2004, p.392).

No hipertexto, a hibridização das linguagens é algo muito característico - e foi impulsionada pelo surgimento dos meios elétricos que propiciaram novas formas de linguagem, associadas às novas formas de comunicação (MONTEIRO, 2004). É possível dividir as linguagens híbridas e caracterizar suas misturas, segundo a classificação das matrizes da linguagem. Em Santaella (2001), encontramos a verbal-visual: gesto, "dança-performance", mímica entre outras.; verbal-sonoro: poesia sonora, canto, rádio, literatura oral; visual-sonoro: a dança, computação gráfica; visual-verbal: anúncio publicitário impresso, escritura, poesia, poesia visual, charge, jornal, enciclopédia; sonoro-verbal: canção; sonoro-visual: música instalação, teatro experimental, vídeo.

A hipermídia está embutida na fusão do sonoro-verbal-visual, que também pode contemplar o circo, o teatro, o cinema, a TV. O ciberespaço, portanto, parece reforçar 
o ambiente da hibridização, já que no mesmo espaço as três matrizes do pensamento e da linguagem estão explicitadas, manifestas e estão em constante interação/troca (MONTEIRO, 2004).

Ainda em Monteiro (2004), faz-se um adendo importante e sujeito à reflexão diante da discussão de misturas de linguagens na hipermídia e hipertexto. Ela nos fornece exemplos de como a internet abarca todas as linguagens anteriores. O site é um exemplo de forma digital impossibilitado de acontecer em outro meio, tal como o hipertexto.

Entretanto o site é a manifestação de todas as outras linguagens. $\mathrm{O}$ que existe atrás do site? Enquanto o homem não aprimora essa nova forma, a tendência é transpor tudo o que foi criado antes para o espaço digital, assim como muitos tentam fazer com a dimensão verbal na hipermídia, isto é, usando o paradigma do livro impresso em linguagem HTML (MONTEIRO, 2004, p. 23).

A conjuntura delineada remete ao que McLuhan (1999) já havia chamado a atenção: no "despertar" de uma nova tecnologia, o homem tende a entornar tudo que havia anteriormente produzido neste novo meio. Conforme exemplifica Monteiro (2004), é o caso da televisão, que trouxe o cinema para dentro dela, assim como o cinema fizera com a literatura.

Apesar disso, nesta discussão, o importante a ser salientado não diz respeito somente às possibilidades de 
combinação de linguagens - mas inclui a produção de sentidos e de percepção. E ainda, se pode dizer que, já que toda linguagem está ligada à percepção, os meios híbridos, ao combinarem duas ou mais matrizes da linguagem, "acabam também por estimular ou promover uma mudança na posição relativa dos sentidos" (MONTEIRO, 2004, p.14).

O que conduz ao pensamento de que os modos de ler passam por transformações, e assim surgem também novos tipos de leitores.

\section{Três tipos de leitores: o contemplativo, o movente e o imersivo}

Se existe uma reconfiguração da prática da leitura no hipertexto e novos caminhos trilhados para interagir com estes textos, é justificável que se explane mais sobre as novas formas de ler e os novos leitores que surgem, ainda que resumidamente. Importante salientar que Santaella (2004) foca não somente nas características de perfil dos leitores, mas ressalta as habilidades que os diferem, e as transformações sensórias e cognitivas.

Marins (2009) reforça a importância de estudar o novo perfil de leitores no atual contexto, já que,

[...] é preciso investigar de que maneira o contato com outros meios de circulação da literatura (adaptações cinematográficas, e-books e jogos inspirados a partir de textos literários) influencia a formação de uma nova identidade leitora, 
estabelecendo relações entre meios semióticos e linguagens bastante distintas (MARINS, 2009, p.01).

Para Hall (2005), a identidade cultural, em virtude da globalização, atravessa mudanças. Na mesma linha, a identidade leitora também se transforma, neste mesmo momento histórico.

Segundo Santaella (2004), existem diferentes tipos de leitores. O primeiro tipo, o leitor da era pré-industrial, que lê de forma contemplativa, e meditativo, preza pela apreciação da leitura em uma época do "auge" do livro impresso e da imagem fixa. Já o segundo perfil de leitor - que nasceu em meio a Revolução Industrial e centros urbanos, é classificado pela autora como aquele que agora tem contato com uma leitura de mais misturas sígnicas. A leitura é mais dinâmica, mais híbrida. E o "terceiro tipo de leitor" é fruto do ciberespaço, da virtualidade.

O leitor contemplativo (meditativo), o primeiro, estabelece uma relação mais íntima e individual com a leitura. Isso é reforçado também pelo aspecto e condições históricas em que surge este leitor. "Com a instauração obrigatória do silêncio nas bibliotecas universitárias na Idade Média central, a leitura se fixou definitivamente como um gesto do olho [...]" (SANTAELLA, 2004, p.20-23).

Já o leitor movente (fragmentário) é fruto de um cenário de constante crescimento das cidades. Surge, um leitor de informações mais fragmentadas, movente, que diversifica as formas de ler, em um mundo que a imagem passa a ser cada vez mais frequente. Com o advento tecnológico em expansão, a evolução da imprensa, dos jornais, o surgimento dos cinemas, e a instantaneidade da 
televisão, o novo leitor ainda endossa características do perfil anterior, "contemplativo", mas passa a ser também mais "instável".

O leitor imersivo, o terceiro tipo, é o próprio do mundo virtual. Está habituado a receber e ler novas informações, de variados formatos e linguagens. O trajeto de sua navegação é alinear, multilinear, traçado por ele mesmo. É fruto da multiplicidade de imagens sígnicas, transita pelas redes, pelo ciberespaço, e por aquilo que Santaella (2004) chama de "nós e conexões", "arquiteturas líquidas". Já é integrante "nato" de grandes centros urbanos, subordinados à linguagem transitória, que está sujeita a constantes mudanças e possui uma percepção aguçada.

Para a autora, há habilidades de leitura distintas que habitam neste novo tipo de leitor, diferentes, principalmente, das habilidades do leitor do livro impresso, contemplativo. Segundo a pesquisadora, ele é "um leitor em estado de prontidão, conectando-se entre nós e nexos, num roteiro multilinear, multissequencial e labiríntico que ele próprio ajudou a construir [...]" (SANTAELLA, 2004, p.33).

Machado (2007) chama a atenção para uma postura mais ativa: "[...] em vez de ser um observador distanciado [...] esse novo sujeito é agora implicado no mundo virtual onde está imerso; sua presença ali é ativa, no sentido de desencadeadora de acontecimentos e no sentido também de estar submetida às forças que ali estão em operação (MACHADO, 2007, p.229 - 230).

Assim, pode-se considerar que existe um novo sentido de leitura que hoje se manifesta pela tela do computador e que acarreta mudanças na forma de leitura e escrita, ampliando o foco da educação para o desenvolvimento 
de habilidades voltadas ao domínio das linguagens que se manifestam no hipertexto, também ao considerar as habilidades que os leitores da nova geração já desenvolveram em meio à cultura digital em que convivem. Este leitor coloca em ação diversos mecanismos e habilidades de leituras, muito distintas daquelas que são empregadas pelo leitor de um texto impresso tradicional como o livro, uma revista ou jornal. Também se observa a interatividade com os conteúdos e o poder deste leitor de interferir na produção, se tornando agora um verdadeiro consumidor e ao mesmo tempo produtor de narrativas, imagens, vídeos etc. no cenário da web 2.0 e do hipertexto. A experimentação por parte dos usuários "dos novos meios" é importante para a evolução das novas linguagens. Como toda linguagem está ligada à percepção, os meios híbridos, ao promoverem o encontro dessas linguagens, estimulam uma mudança na percepção dos leitores- e diferentes estruturas perceptivas desencadeiam diferentes mecanismos de compreensão e adquirem diferentes significados.

Além de novos leitores, os novos produtores de informação caracterizam este novo espaço e moldam um novo contexto para a informação e para as narrativas, que passa a ser cada vez mais multimodal ${ }^{2}$.

\section{O produtor de conteúdos da web}

Com o avanço das novas tecnologias, há um aumento na produção, que passa a ser constante, de mensagens textuais, sonoras e visuais em nossas vidas. Assim,

2 Contexto multimodal é aquele que aproveita simultaneamente as diversas linguagens: a sonora, a visual e a verbal. 
"passamos a ter uma relação mais pessoal e dinâmica com a informação e a interação mais frequente com as fontes [...]"(KENSKI, 2007, p.34).

Qualquer um pode informar e ser informado na rede, e estes processos serão melhor "dominados" se competências suficientes forem desenvolvidas. Essa capacidade de participar de forma efetiva em rede define o nível de "empoderamento" de cada pessoa em relação ao seu próprio desenvolvimento e conhecimento. Não são somente as habilidades de comunicação e interação que estão em jogo.

Assim, longe de ser decididamente pós-moderno, o ciberespaço pode surgir como uma espécie de materialização técnica dos ideais modernos. Em particular, a evolução contemporânea da informática constitui uma impressionante realização do objetivo marxista de apropriação dos meios de produção pelos próprios produtores. Hoje, a "produção" consiste essencialmente em simular, em tratar a informação, em criar e difundir (LEVY, 1999, p.227).

A lei da liberação do polo de emissão gera uma remodelagem da cadeia produtiva de mídia, nas etapas de produção, empacotamento e distribuição (PRADO, 2007). Há uma mudança visível no aspecto da comunicação vertical (autoritária, de cima para baixo, unilateral) para a 
comunicação horizontal (mais interatividade entre emissor e receptor).

Mudam-se, com preponderância, os aspectos relacionados ao receptor, que agora vira produtor de conteúdo no cenário da web 2.0. Uma das ferramentas digitais que marcaram essa atuação do receptor como produtor de conteúdo foram os blogs, espaços na internet que intervêm na atividade jornalística, na literatura etc. Como afirma Lemos (2010), os blogs, como canais de publicação, são a oportunidade para que o receptor "realize" seu desejo antes reprimido na cultura de massas: o de ser ator na emissão, de produzir e emitir informação, sem depender de intermediários. E ainda, o mesmo estudioso identifica que este fenômeno está ligado a movimentos da cultura punk, que prega o "faça você mesmo, produza informação". Assim:

A liberação do polo de emissão e as facilidades de manuseio das tecnologias digitais promoveram uma cultura mais participativa, onde todas as pessoas, com mínimos recursos, podem divulgar obras de arte, textos, notícias, filmes e músicas para um número amplo de pessoas conectadas à rede mundialmente (GONÇALVEZ, 2011, p. 81).

Há assim uma significativa mudança entre a "comunicação de um para todos" e a "comunicação de todos para todos". "A lógica da cibercultura é a do "e, e, e..." e não do "ou isso ou aquilo" (LEMOS, 2004, p.18). 
Apesar dessa manifestação, fruto de uma prática sociocultural contemporânea, indicar que se vivencia um relativo "excesso informacional", Lemos (2005) prefere chamar isso de uma situação de "emergência de vozes e discursos, anteriormente reprimidas, em consequência do então existente monopólio de edição da informação pelos meios de comunicação de massa. Aqui a máxima é "tem de tudo na internet", "pode tudo na internet" (LEMOS, 2005, p.2).

Essa transição gera conflitos, pois o papel de comunicador deixa de estar restrito a um grupo midiático, que antes detinha o poder de veicular informação em larga escala. Agora, o cidadão comum também pode produzir informações através das mídias sociais (Facebook, YouTube, blogs etc), o que gera crise no modelo de jornalismo tradicional e na indústria cultural. $\mathrm{O}$ cidadão comum também tem o poder de fazer chegar suas informações a um grande número de pessoas. A mídia tradicional fica mais sujeita a receber críticas, que não são mais possíveis de serem controladas. Outras facetas da informação e dos fatos são mostrados para além do recorte da mídia tradicional.

A liberação do polo da emissão é uma das fundamentais e primeiras características da cultura digital "pós-massiva". O antigo "receptor", visto por muitos teóricos como "passivo", de fácil manipulação, agora passa a ter uma postura ativa bem definida diante das redes. Ele produz e emite sua própria informação, de forma livre e multimodal (por meio de vários formatos midiáticos) e planetária (LEMOS, 2004). Isso é visto facilmente pelas práticas sociocomunicacionais de indivíduos das mais diversas faixas etárias na internet: usuários escrevendo 
blogs, produzindo vídeos, música, criando fóruns e comunidades, e também desenvolvendo softwares e mais ferramentas da web 2.0.

Essas práticas refletem a potência represada pelos meios massivos de comunicação que sempre controlaram o polo da emissão. Editoras, empresas de televisão, jornais e revistas, indústrias da música e do filme controlam a emissão na já tão estudada cultura da comunicação de massa. Na indústria cultural massiva, há um emissor de informação que dirige sua produção para uma massa de receptores, transformada, com alguma sorte, em público. Isto não significa que não havia possibilidades de acesso e produção underground da informação: fanzines, rádios e TVs piratas etc. sempre existiram, mas com alcance bastante limitado. A evolução da tecnologia eletrônico-digital cria uma efervescência, um excesso de informação pela possibilidade de que cada um seja também produtor e emissor de conteúdo. Exceção feita, claro, aos países de regime totalitário/autoritário que buscam controlar e filtrar a rede, cercear a produção, a circulação e o consumo da informação, como é o caso da China (LEMOS, 2009, p.39). 
Lévy reconhece que a liberação do polo de emissão liga-se a um movimento internacional "de jovens ávidos para experimentar, coletivamente, formas de comunicação diferentes daquelas que as mídias clássicas nos propõem" (LÉVY, 1999, p.08). E ainda, admite que o ciberespaço, apesar de acarretar problemas relacionados à informação, abre um novo espaço de comunicação, cabendo aos usuários explorar as potencialidades deste espaço, em diversos âmbitos.

Nas palavras de Lévy:

Não quero de forma alguma dar a impressão de que tudo o que é feito com as redes digitais seja "bom". [...] peço apenas que permaneçamos abertos, benevolentes, receptivos em relação à novidade. Que tentemos compreendê-la, pois a verdadeira questão não é ser contra ou a favor, mas sim reconhecer as mudanças qualitativas na ecologia dos signos, o ambiente inédito que resulta da extensão das novas redes de comunicação para a vida social e cultural. Apenas dessa forma seremos capazes de desenvolver estas novas tecnologias dentro de uma perspectiva humanista (LÉVY, 1999, p.09).

Pensar na liberação do polo de emissão também nos remete a pensar em impactos sociais e políticos. O empoderamento da informação e a capacidade de transmiti-la 
por meio de mídias, como aparelhos celulares, de maneira planetária, fez com que, por exemplo, muitas informações e imagens passassem a circular referentes aos tsunamis, aos atentados em Madrid e em Londres, assim como as manifestações em torno da "Primavera Árabe" - imagens, vídeos e demais informações foram disseminadas por diversas pessoas ao redor do mundo. As guerrilhas urbanas ocorridas em Paris foram não só documentadas - o emissor e transmissor de informação de mídias móveis, de alguma maneira, acabam por virar até prova testemunhal, "como no caso de um indivíduo que filmou, da janela de sua casa, através de um telefone celular, a polícia agredindo jovens da periferia. Esse vídeo, disseminado pela rede, em blogs, aumentou ainda mais a revolta" (LEMOS, 2009, p.40). São os blogs, os podcasts, o Facebook etc. favorecendo a atuação dos chamados "citizen media", ou "mídia do cidadão", plataformas que incentivam o usuário a produzir, distribuir e reciclar conteúdos digitais, fazendo verdadeiras releituras de textos literários, opinando sobre a política, matérias jornalísticas etc. Abre-se campo para a ação dos verdadeiros "cidadãos digitais".

Assim, com a liberação da emissão, temos testemunhas que podem produzir e emitir de forma planetária os diversos tipos de informação. Esses exemplos são comprovações da potência da liberação da emissão na atual cibercultura recombinante. Isto nos leva ao segundo princípio: a conexão (LEMOS, 2009, p. 40). 
Dentro da lei da liberação do polo de emissão, temos o surgimento de novos produtores de informação, que se comunicam principalmente por meio das redes sociais baseando-se em um princípio que rege a cibercultura, o chamado remix - o "conjunto de práticas sociais e comunicacionais de combinações, colagens, cut up de informação a partir de tecnologias digitais" (LEMOS, 2005, p.01). "O remix tem suas bases nas misturas, no sincretismo e no pluralismo cultural e se traduz pela possibilidade de apropriação, de desvio e de criação livre a partir de diversos formatos, modalidades e tecnologias" (GONÇALVEZ, 2011, p.32).

Os remixers combinam e recombinam, modificam as imagens. De acordo com Gonçalvez (2011), o produtor que segue a lógica do remix manipula um conteúdo já existente para criar um novo conteúdo. Os remixers dominam as ferramentas que a tecnologia digital oferece.

\section{As multiliteracias para um novo contexto de leitura e produção da informação}

Esforços têm sido feitos para a valorização do livro, da leitura e das bibliotecas e no combate ao analfabetismo. Um exemplo disso, no Brasil, é o Plano Nacional do Livro e Leitura (PNLL), que traça diretrizes para uma política pública voltada à leitura e ao livro no Brasil, com quatro eixos organizadores: democratização do acesso, fomento à leitura e à formação de mediadores, valorização institucional da leitura e incremento de seu valor simbólico e desenvolvimento da economia do livro (BRASIL, 2014).

Por mais que se pregue que a situação de leitura e acesso aos livros no Brasil é precária, uma pesquisa 
recente, intitulada "Retratos da leitura no Brasil", aponta aumento do número de livros lidos por leitor em 2015, se comparado ao ano de 2011: saltando de 1,85 em 2011, para 2,54 em 2015. A amostra foi de 5.012 entrevistas, mesma quantidade que em 2011, envolvendo a população brasileira, com 5 anos e mais, alfabetizada ou não (INSTITUTO PRÓ-LIVRO, 2016).

Mas, mais do que dados, é importante ficar atento que tipo de leitura, e que tipo de livros vêm sendo mais lidos. Na pesquisa da edição mais atual, a Bíblia segue no topo da lista de livros mais lidos e citados. A seguir, aparecem contos e romances - muitos deles, indicados na escola para o vestibular. Livros "best seller" também são bastante lidos, tais como "A culpa é das estrelas", "A cabana", "O pequeno príncipe", "Cinquenta tons de cinza", entre outros. E a leitura de outros materiais, como jornais, é mais frequente que a leitura de livros propriamente dita.

Ler ainda não é o hábito preferido do brasileiro em seu tempo livre, que elegeu assistir à televisão como passatempo predileto. Usar a internet e o Facebook, Twitter ou Instagram são hábitos que têm crescido entre os leitores pesquisados. O estudo aponta que, de forma geral, o tempo livre dos brasileiros está cada vez mais ocupado por uma variedade de atividades, e o uso da Internet segue ganhando destaque, assim como o acesso e uso de redes sociais.

Um dos dados interessantes diz respeito às atividades relacionadas à leitura que se realiza na internet: para fins de leitura, em primeiro lugar, os leitores responderam que usam a internet para ler notícias e informação em geral; em segundo lugar, usam para estudar, fazer trabalho escolar ou pesquisar temas escolares. Em terceiro lugar, os leitores usam para aprofundar temas de seu interesse. 
Levar em conta esses dados é importante para considerar que, de fato, a internet e seus conteúdos têm sido "lidos" constantemente. De maneira alguma, isso significa dar menos importância para o livro impresso e a leitura tradicional, mas admitir que não são somente essas as únicas formas de ler, os únicos suportes, e nem que a leitura, necessariamente, precise estar associada à obrigação escolar; nem somente a algum tema científico e acadêmico.

É preciso não somente reconhecer novos suportes de leitura, mas também diversos conteúdos também como textos a serem lidos, que exigem habilidades de leitura diferentes. E, também, reconhecer que existem mais formas de interação, e quanto mais possibilidades de formar produtores que dominem habilidades de produção de conteúdo, melhor. Importante ressaltar que a produção de conteúdos não deve estar relacionada apenas ao domínio técnico dos aparatos de comunicação, mas o domínio da linguagem também tem que estar atrelado a uma produção ética.

Descentralizar o eixo verbal e considerar o não verbal, assim como desenvolver a competência leitora/produtora para ler e produzir os mais variados textos é também o que defende o próprio Plano Nacional do Livro e da Leitura: "ao reafirmar a centralidade da palavra escrita, não se desconsidera a validade de outros códigos e linguagens, as tradições orais e as novas textualidades que surgem com as tecnologias digitais" (BRASIL, 2014, p.17). E ainda:

No contexto atual, é imperativo que a leitura seja tratada no diálogo com as diversas tecnologias de gravação, entre as quais o livro se encontra. 
Como defende Renato Janine Ribeiro, a maneira adequada de difundir a leitura no Brasil não é a de sua "tradição", mas aquela que considera que o sujeito contemporâneo só consegue ser interativo com a mídia sendo, ele mesmo, "multimeios", necessitando da leitura para sê-lo. No mundo de hoje, não apenas a prática leitora deve passar pelo uso das tecnologias de informação e comunicação, mas o usuário dessas tecnologias deve desenvolver, por intermédio da família, da escola e de uma sociedade leitora, a prática de leitura. Neste sentido, deve-se ter atenção às questões contemporâneas acerca dos direitos autorais, fortemente impactados pelas novas possibilidades tecnológicas e seus avanços em termos de possibilidade de gravação e cópia (BRASIL, 2014, p. 17).

Assim, hoje, quando se fala de apropriação crítica de informação, temos que considerar a necessidade de alfabetização para as novas formas de ler e produzir textos, ampliando nosso conceito de leitura e do que é ser alfabetizado. Segundo Almeida Júnior (2006), atravessamos uma era em que se perpetua, além do texto escrito, a imagem fixa, a imagem em movimento, e o som. Segundo o autor, as pessoas são analfabetas na leitura dessas outras mídias (e linguagens), por achar que não existe a necessidade de aprendizado dessas linguagens, que é algo 
natural. "Não há uma cartilha para o aprendizado delas. É importante lembrar que elas possuem linguagens próprias, específicas e sua leitura precisa do conhecimento dessas linguagens para se concretizar, para se efetivar" (ALMEIDA JUNIOR, 2006, p.53).

A discussão, portanto, nos remete a expandir o conceito de alfabetização, caminhando para olhar para as multiliteracias, as alfabetizações múltiplas ou multilectoescrituras, que consideram que mudanças locais, mundiais, sociais, culturais e tecnológicas influenciaram os modos de ler, escrever, produzir informação, segundo os autores Anstey e Bull (2007). Assim, não faz mais sentido centrar-se na palavra impressa somente.

El conjunto de herramientas para la lectura y escritura presente en los años cincuenta [...] estaba centrado principalmente en las tecnologías de la letra impresa, es decir, las palabras escritas y leídas. Si bien algunos textos contaban con ilustraciones, diagramas y fotografías, el foco de la enseñanza y el aprendizaje estaba en la interpretación del significado único de una palabra impresa, mientras que se le daba poca importancia al rol, o a la lectura, del entorno ilustrativo o diagramático. De modo similar, se ignoraba la influencia del diseño de página sobre el significado. Este conjunto básico de herramientas de lectura y escritura, dominado 
por la palabra impresa, era útil en un mundo donde los puestos de trabajo eran seguros, generalmente ocupados durante toda la vida, y en los que se requería una serie de habilidades básicas con las tecnologias de ese momento: bolígrafo y papel, o máquina de escribir y papel (ANSTEY; BULL, 2007, p.43).

Por mais que as habilidades múltiplas associadas à capacidade de ler e escrever tenham sido cada vez mais valorizadas no mundo atual, além do fato de que a imagem e o audiovisual têm sido cada vez mais fonte de informação e "matéria prima" de um novo perfil de produtor de informação, observa-se ainda que a imagem e outras linguagens não-verbais têm sido, não poucas vezes, mais utilizadas como instrumento ilustrativo. Para exemplificar esta situação no contexto escolar, Champangnatte e Nunes (2011) analisaram que os professores utilizavam as mídias como recurso ilustrativo aos conteúdos que trabalhavam, servindo apenas como complemento. As atividades envolvendo o audiovisual, por exemplo, não geravam discussões, leitura crítica, nem tampouco questionamentos. "O uso da mídia em sala de aula que mais predominou foi a utilização como ilustração, tanto na utilização do vídeo quanto da internet. Nesse tipo de abordagem, a mídia é usada para exemplificar determinados pontos de um conteúdo trabalhado" (CHAMPANGNATTE; NUNES, 2011, p. 32).

Nesta mesma concepção, um leitor que é "multiliterado", na visão de Anstey e Bull (2007), deve compreender 
a interferência cada vez maior da diversidade social, cultural e linguística na leitura e escrita e nas práticas alfabetizadoras. É ainda capaz de manipular a leitura e escrita de maneira crítica, para participar da sociedade como um cidadão ativo e bem informado. O leitor com múltiplas habilidades de leitura e escrita ainda compreende a tecnologia e o desenvolvimento dos textos multimodais, sabendo como utilizar diferentes tipos de textos e de tecnologias, assim como textos que se valham de sistemas semióticos individuais ou combinados. E, importante: a pessoa "multiliterada" é flexível e compreende que a alfabetização é dinâmica e não estática, e se modificam diante das transformações sociais, culturais e tecnológicas.

Nesse cenário, cabe tanto à escola como a outras instituições formadoras fomentar as novas alfabetizações, valorizando as habilidades de leitura do leitor contemporâneo. Valorizar as leituras ligadas por meio de hiperlinks, não-sequencial, que exigem habilidades para entender o significado não só da palavra impressa, mas do som, do vídeo, diante da tela do computador, do tablete, do celular, podem ser atividades a serem desenvolvidas. A interatividade proporcionada pelos novos meios, os diversos aplicativos e softwares que estimulam a produção de diversos tipos de textos, a gravação de vídeos, o trabalho "transmídia" - de contar a mesma história ou disseminar as mesmas informações em diversos veículos de comunicação, linguagens e plataformas - podem ser meios de produção de conhecimento, assim como meios para se expressar. Dessa forma, escrever um texto impresso não é mais o único caminho. Por exemplo, o aluno pode expressar o que aprendeu fazendo uma história em quadrinhos, 
gravando um vídeo, fazendo um "meme", uma produção remix, entre muitas outras possibilidades.

O alerta é para que o trabalho multimodal na educação valorize as novas tecnologias, linguagens híbridas e diferentes mídias, não se concentrando apenas no desenvolvimento de habilidades técnicas para o uso de mídias e tecnologias. A leitura crítica sobre o uso de uma determinada linguagem, sobre o uso de uma tecnologia, também deve ser levada em consideração.

Enfim, espera-se que o presente texto possa contribuir para: a compreensão do contexto cibernético contemporâneo em que crianças e jovens nasceram imersos, assim como do cenário de alfabetização digital que desafia educadores. Adicionalmente, há o interesse de suscitar a elaboração de novas ideias que explorem à multimodalidade, a produção transmídia, o remix e também incentivem a leitura e a produção textual nas salas de aula, que se apropriem das três matrizes de linguagem.

\section{REFERÊNCIAS}

ABREU, J. G.; MONTEIRO, S. D. Matrizes da linguagem e a organização virtual do conhecimento. Ciência da Informação, Brasília, v.39, n.2, p.9-26, maio/ago., 2010.

ALMEIDA JÚNIOR, O. F.. Bibliotecário escolar: seu perfil, seu fazer. In: ROVILSON, José da Silva; BORTOLIN, Sueli. (Org.). Fazeres cotidianos da biblioteca escolar. São Paulo: Polis, 2006, p.43-54.

BRASIL. Ministério da Cultura. Caderno do Plano Nacional do Livro e Leitura - PNLL: Edição atualizada 
e revisada em 2014. Brasília, DF. Disponível em: <http:/ / www.cultura.gov.br/pnll>. Acesso em: 20 set. 2016.

CHAMPANGNATTE, D. M. O.; NUNES, L. C. A inserção das mídias audiovisuais no contexto escolar. Educação em Revista, Belo Horizonte, v. 27, n.3, p.15-38, dez. 2011. Disponível em: <http://www.scielo.br/pdf/edur/ v27n3/v27n3a02.pdf>. Acesso em: 23 set. 2016.

DAWKINS, Richard. The selfish gene. Oxford: Oxford University Press, 1989.

GONÇALVEZ, R. Conteúdos culturais na cibercultura: um estudo do processo de convergência midiática da obra de Clarah Averbuck. 2011. 103 f. Dissertação (Mestrado) - Curso de Letras, Universidade Federal de São João Del Rei, São João Del Rei, 2011. Disponível em: <http:// www.ufsj.edu.br/portal2-repositorio/File/mestletras/ DISSERTACOES_2/conteudos_culturais_ na_cibercultura.pdf>. Acesso em: 10 set. 2016.

HALL, S. A identidade cultural na pós-modernidade. Trad. Tomaz Tadeu da Silva e Guacira Lopes Louro. 10 ed. Rio de Janeiro: DP\&A, 2005.

INSTITUTO PRÓ-LIVRO.Brasil. Retratos da Leitura no Brasil.4. ed.São Paulo: Ibope Inteligência, 2016. Disponível em: $\quad<$ http://prolivro.org.br/home/images/2016/ Pesquisa_Retratos_da_Leitura_no_Brasil_-_2015.pdf $>$. Acesso em: 03 out. 2016.

KENSKI, V. M. Educação e tecnologias: o novo ritmo da informação. Campinas, São Paulo: Papirus, 2007. 
LEMOS, A. Cibercultura, cultura e identidade. Em direção a uma cultura Copyleft? Contemporânea - Revista de Comunicação e Cultura, Bahia, v.2, n.2, p.09-22, dez. 2004. Semestral. Disponível em: <http://www.portalseer.ufba.br/index.php/contemporaneaposcom/article/ viewFile/3416/2486>. Acesso em: 03 set. 2016.

. Cibercultura e remix. In: Seminário Sentidos e Processos. São Paulo: Itaú Cultural. Ago. 2005. Disponível em: <http://www.facom.ufba.br/ciberpesquisa/andrelemos/remix.pdf >Acesso em: 20 set. 2016.

. Cibercultura como território recombinante. In. TRIVINHO, Eugênio; CAZELOTO, Edilson. A cibercultura e seu espelho: campo de conhecimento emergente e nova vivência humana na era da imersão interativa. São Paulo: ABCiber ; Instituto Itaú Cultural, 2009. p.3851. (ColeçãoABCiber). Disponível em: <http://abciber. org/publicacoes/livro1/a_cibercultura_e_seu_espelho. pdf>Acesso em: 24 set. 2016.

LEVY, P. Cibercultura. São Paulo: Editora 34, 1999.

MACHADO, A. O sujeito na tela: modos de enunciação no cinema e no ciberespaço. São Paulo: Paulus, 2007.

MARINS, L. C. A circulação multimodal e intermidial do texto literário e sua recepção por alunos de letras. In: CONGRESSO DE LEITURA DO BRASIL (COLE), 17., 2009, Campinas. Anais do $\mathbf{1 7}^{\circ}$ COLE. Campinas: Unicamp, 2009. p. 01 - 08. Disponível em: <http://alb. com.br/arquivo-morto/edicoes_anteriores/anais17/ 
txtcompletos/sem16/COLE_977.pdf>. Acesso em: 30 set. 2016.

MCLUHAN, M.. Os meios de comunicação como extensões do homem. São Paulo: Cultrix, 1999.

MONTEIRO, Silvana Drumond. As linguagens e o hipertexto: uma introdução às possibilidades discursivas na forma hipertextual. 2004. 33 f. Dissertação (Doutorado em Comunicação e Semiótica) - Pontifícia Universidade Católica (PUC), São Paulo, 2004. Disponível em: <http:/ / www.pucsp.br/ cimid/8inf/monteiro/linghipe. pdf>. Acesso em: 09 ago. 2016.

PRADO, Luiz Carlos Delorme. Convergência e defesa da concorrência: considerações sobre novos mercados relevantes e riscos de concentração. Conferência Nacional Preparatória de Comunicações. Brasília, 2007.

REGIS, Sônia. Percepção, linguagem e pensamento. Galáxia, São Paulo, n.3, p.241-251, 2002.

SANTAELLA, L. Matrizes de linguagem e pensamento. São Paulo: Iluminuras, 2001.

. Navegar no ciberespaço: o perfil cognitivo do leitor imersivo. São Paulo: Paulus, 2004. 


\title{
DISEÑO E IMPLEMENTACIÓN DE PROYECTOS INTERCULTURALES EN LA FORMACIÓN DOCENTE
}

\author{
María Isabel Pozzo (UNR)
}

En la República Argentina, la formación docente se desarrolla mayormente -aunque no exclusivamente- en los Institutos de Formación Docente (IFD), los cuales se ubican en el subsistema de educación superior no universitaria. Tradicionalmente, constituyeron un ámbito relegado del sistema educativo, ofuscado por las problemáticas imperiosas del ciclo educativo obligatorio y por el reconocimiento social del que goza el nivel universitario. La creación del Instituto Nacional de Formación Docente (INFD) en el marco de la vigente Ley de Educación Nacional, del 2006, vino a revertir este relegamiento, generando un ámbito específico en el cual prestar la imprescindible atención que merece la formación docente. En el nivel regional de la provincia de Santa $\mathrm{Fe}$, una de las zonas geográficas más pobladas y económicamente pujantes del país austral, la Secretaría de Ciencia, Tecnología e Innovación de la provincia de Santa Fe (hoy devenida 
en Ministerio) inauguró en 2013 el Programa de fortalecimiento de las capacidades del sistema de investigación y desarrollo en la provincia de Santa Fe para proyectos de investigación. Específicamente, creó un Instrumento de Apoyo y estímulo a Proyectos de investigación entre los Institutos de Educación Superior de la provincia y el Sistema científico radicado en el territorio provincial. Se trataba de una convocatoria nueva, tendiente a promover el desarrollo de la investigación en dichos institutos en virtud del trabajo conjunto con instituciones dedicadas a la investigación (como el Instituto Nacional de Tecnología Agropecuaria (INTA), el Instituto Nacional de Tecnología Industrial (INTI), o el Concejo Nacional de Investigaciones Científicas y Técnicas (CONICET).

En dicho marco, un equipo argentino coordinado por quien suscribe, presentó una propuesta a dicha convocatoria en una línea de trabajo que venía realizando desde hace tiempo, entre instituciones que tenían que ver, precisamente, con el perfil estipulado, pero que podían verse fortalecidos con el apoyo de un ente provincial de esta talla. En tanto la propuesta resultó seleccionada, se concretó un cluster interinstitucional compuesto por el Instituto Rosario de Investigaciones en Ciencias de la Educación (IRICE) del CONICET, el Instituto de Educación Superior (IES) - No 28 "Olga Cossettini" de Rosario. Además de las instituciones participantes acorde a la convocatoria, están presentes otras del subsistema universitario, tanto argentino como extranjero: el Centro de Estudios del Español como Lengua Extranjera y la Escuela de Ciencias de la Educación de la Universidad Nacional de Rosario, Argentina, la Universidad de Aarhus, Dinamarca, y la Universidad de Salerno, Italia. 
La convocatoria estipulaba desarrollar proyectos de investigación orientados a temas de interés provincial, los cuales se plasmaban en un listado establecido por la Secretaría de Ciencia, Tecnología e Innovación y el Ministerio de Educación al momento de la convocatoria. De todos ellos, el eje $\mathrm{n}^{\circ} 10$ : "Migraciones, pueblos originarios, multiculturalidad", se relacionaba con la línea de investigación del Área de estudios interculturales a mi cargo en el Instituto Rosario de Investigaciones en Ciencias de la Educación (IRICE-CONICET), así como los estudios que veníamos desarrollando en el Centro de Estudios del Español como Lengua Extranjera de la Facultad de Humanidades y Artes de la Universidad Nacional de Rosario.

En base a dichas convergencias temáticas, conformamos un grupo de profesores, graduados y estudiantes con quienes, en su mayoría, ya habíamos compartido proyectos previos y/o nos encontrábamos trabajando en conjunto en carácter de tesistas, becarios, alumnos o colegas. Constituimos así un equipo interdisciplinario formado en distintas disciplinas (Ciencias de la Educación, Historia, Letras, Inglés, Comunicación Social, Psicopedagogía). Otro rasgo a destacar es que, si bien casi todas somos argentinas, algunas residen desde hace mucho tiempo en el extranjero, situación que nos facilitó el trabajo con instituciones de otros países.

El antecedente más directo (por la composición del equipo, el perfil institucional y su temática) fue el proyecto “Una propuesta de desarrollo disciplinar e intercultural en la formación y perfeccionamiento docentes a partir de la alfabetización de migrantes en la ciudad de Rosario". Esta propuesta fue seleccionada y subsidiada por el Instituto 
Nacional de Formación Docente (INFD) en la convocatoria 2007 de proyectos concursables de investigación pedagógica "Conocer para incidir sobre los aprendizajes escolares". También en dicha oportunidad se trataba de una nueva estrategia institucional tendiente a promover la investigación en los Institutos de Formación Docente - aunque en dicha oportunidad, promovida por la esfera nacional -. El trabajo resultante arrojó un libro de autoría colectiva publicado en Alemania (POZZO, ed., 2009), además de ponencias y artículos. Como hicimos en dicha oportunidad, el proyecto relatado en este capítulo fue plasmado en una obra grupal (POZZO, ed., 2015), en la que los distintos capítulos reflejan distintos tramos del trabajo realizado desde el año 2014. El libro contó con el referato a cargo de un prestigioso comité académico conformado por la Dra Elena Achilli, profesora de la Universidad Nacional de Rosario, la Dra. Melina Porto (Universidad Nacional de La Plata y CONICET) y el Dr. José María Izquierdo (Federación Internacional de Asociaciones de Profesores de Español -FIAPE- y Universidad de Oslo, Noruega). A su vez, el libro está prologado por el Dr. Maximiliano Ritacco Real, un argentino originario de Bahía Blanca que se desempeña como profesor en el Departamento de Ciencias de la Educación de la Universidad de Zaragoza. Este encuadre institucional más el propio proyecto están descriptos en el primer capítulo (POZZO, 2015).

Además de dicho libro, plasmamos nuevos resultados en posteriores ponencias y artículos, por lo que este capítulo configura una puesta al día de nuestro trabajo. Asumimos las actividades de difusión con el convencimiento de que todo conocimiento producido recién finaliza su proceso cuando se socializa. 


\section{Proyectos interculturales en la formación docente}

Examinar la temática de la interculturalidad en la formación docente admite diversas puertas de ingreso. Una muy fecunda es la reflexión sobre la categoría de competencia comunicativa intercultural (CCI), propuesta originariamente por Byram (1997) y adoptada en un documento tan influyente como en Marco Comúne Europeo de Referencias para las lenguas (CONSEJO DE EUROPA, 2002). Su definición requiere remontarse a un examen de la noción de competencias, llevando luego la reflexión a la particularidad de la CCI (POZZO; PIDELLO, 2015). Nos proponemos cubrir la vacancia que existe en torno a la figura del profesor, dado el importante rol que les cabe como responsables de promover dicho desarrollo y por el especial interés que reviste en su reposicionamiento como transmisor cultural.

Otros abordajes vinculan el concepto de competencia comunicativa intercultural con el de comunicación didáctica (PAROLA, 2015). Al tratarse este último de un contenido habitualmente frecuente en los Programas de las asignaturas pedagógicas, es factible vincular la reflexión teórica desde diversas materias (por ejemplo: Ateneo de Educación Superior con Teoría del Curriculum) e incluso profesorados. A su vez, considerando la composición multicultural de la sociedad actual es posible encararlo con una experiencia áulica a partir de la presencia de estudiantes extranjeros. Los Profesorados de Lenguas Extranjeras suelen contar además con asistentes de lengua. Temas relativos a la interculturalidad y formación docente son también motivo de cursos de capacitación extracurriculares, los cuales resultan muy propicios para 
relevar concepciones de los docentes acerca de qué es la interculturalidad (FERNÁNDEZ; DAVANTURE, 2015).

Partir de situaciones de distancia cultural en escenarios naturales (no experimentales) de la formación docente requiere una fase de diagnóstico tendiente a describir el contexto institucional en cuanto a la presencia de migrantes y visitantes en la educación superior. Al respecto cabe tener presente la relevancia de la movilidad académica estudiantil como objeto de estudio. Vale decir, las oportunidades existentes en cuanto a convocatorias, pero también cómo estas han sido motivo de investigación en cuanto al logro de sus objetivos, sus continuidades y rupturas, etc (VIRGOLÍN; POZZO, 2015). En tal sentido, la peculiaridad de la educación superior no universitaria en Argentina mencionada previamente requiere un examen específico de los programas de movilidad académica disponibles para la formación docente (BERTRAMO; D'ASCANIO; POZZO, 2015). Nuestro cotejo dejó ver la menor disponibilidad de oportunidades para los institutos terciarios, a cargo principalmente de las instituciones de lenguas extranjeras (Alianza Francesa o Concejo Británico) y, de manera reciente, por el INFD. Tras este encuadre general sobre el estado de situación de la internacionalización de la educación superior en Argentina, nos abocamos a nuestro caso en estudio, el Instituto de Educación Superior $\mathrm{N}^{\circ} 28$ "Olga Cossettini" de Rosario, Argentina. Allí realizamos un estudio situado de la presencia de extranjeros por dos medios: a través de un exhaustivo relevamiento a través del Sistema de Gestión Escolar Web (SIGAE) del Ministerio de Educación de la Provincia de Santa Fe (AMEZ, 2015), y por medio de entrevistas abiertas para conocer las historias de los estudiantes extranjeros en el Instituto desde su 
propia percepción (BERTRAMO; D'ASCANIO; POZZO, 2015). Y considerando que nuestra población objeto son futuros docentes de escuela media, relevamos el perfil de los estudiantes de intercambio, que constituyen el grupo más numeroso de extranjeros en las escuelas secundarias argentinas (JACOB; POZZO, 2015a).

Una vez realizados los estudios diagnósticos a escala nacional, regional e institucional en torno al caso en estudio, es posible iniciar la fase de intervención. Partimos de la unidad de análisis que hemos dado en llamar "espacios interculturales" -tomando la expresión de DÍAZ; ALONSO (2004) a partir de la presencia de población extranjera en la institución según se desprende del relevamiento de la fase anterior y fuera de ella por medio de las TICs. Dichos espacios se tornan en proyectos una vez que alcanzan una acción planificada al interior del grupo-clase, sea en una o varias asignaturas y carreras en la formación docente. Para diseñar e implementar nuestros proyectos interculturales, seleccionamos carreras humanísticas de la formación inicial que se dictan en el Instituto de Formación Docente seleccionado: los Profesorados de Francés lengua Extranjera e Historia, cuya formación didáctica examinamos (D'ASCANIO; BERTRAMO; POZZO, 2015). Dentro de estas carreras identificamos espacios curriculares cuyos contenidos pueden articularse a un proyecto intercultural. Asimismo, resolvimos incluir el área artística, para lo cual fue necesario recurrir a otra institución de formación docente en la cual esta área integra el curriculum. Así, involucramos a los Profesorados de Nivel Inicial y Primaria de la Escuela Provincial No 35 (ex Normal No 2 ) de Rosario. 
En dichos marcos, diseñamos e implementamos proyectos interculturales valiéndonos de dos instancias:

1) la presencia de estudiantes extranjeros en situación de movilidad (migrantes y estudiantes de intercambio);

2) las posibilidades de intercambio con población extranjera que proporcionan las TICs.

En el primer caso, implementamos un taller de reflexión en torno a distintos tópicos asociados al tema de la interculturalidad (PAROLA, 2015). El espacio elegido fue el de Teoría del Curriculum en el Profesorado de Francés, que es el que contiene la mayor cantidad de población extranjera, principalmente haitianos (según se advierte en AMEZ, 2015a). La reflexión dio lugar a una investigación de campo en el que los docentes en formación diseñaron un protocolo de encuesta y lo aplicaron a profesores y estudiantes nativos y extranjeros.

En la clase de educación artística en la formación de maestros, los estudiantes identificaron distintas producciones musicales de la ciudad, analizando los marcos de recepción de las mismas (POLO, 2015). Tanto los estudiantes del profesorado de francés como los de magisterio plasmaron los resultados obtenidos en producciones audiovisuales disponibles en el sitio web del proyecto ${ }^{1}$.

Con los alumnos del Profesorado de Historia diseñamos un proyecto intercultural mediado por las TICs en conjunto con cursos de español de universidades extranjeras no hispanohablantes cuyas profesoras pertenecen a

1 https://sites.google.com/site/espaciosinterculturales/ el-proyecto. 
nuestro equipo de investigación. Una de ellas es Susana Fernández (de la Universidad de Aarhus, Dinamarca), para cuyos alumnos se confeccionó el texto histórico que sustentó el intercambio virtual (GARCÍA; POZZO, 2015a). La otra profesora es Margarita Theiner (de la Universidad de Salerno, Italia), con cuyos alumnos estructuramos el intercambio en torno a entrevistas sobre temáticas locales (THEINER; POZZO, 2015). Estos proyectos inauguran el eje de cultura regional de nuestro proyecto, ya que refiere a la provincia de Santa $\mathrm{Fe}$, en la cual está ubicada nuestra ciudad de Rosario, en tiempos de la colonia español. Vale decir que acercamos a estudiantes europeos de español a cuestiones de nuestra provincia, que a la luz de Hispanoamérica resulta un punto pequeño, y sin embargo, digno de atención. Además del contenido que estructura el intercambio, realizamos una reflexión sobre la experiencia de telecolaboración (FERNÁNDEZ; POZZO, 2015) para considerar en futuras réplicas.

A partir del interés que suscitaron estas iniciativas entre nuestros contactos internacionales, implementamos un proyecto similar en esta modalidad con una escuela secundaria de Francia (BÉRODOT; POZZO, 2015). La diferencia de edad entre los participantes marcó una situación homologable a la que tendrán los futuros docentes de Historia, a lo que se suma la ventaja lingüística de los mayores al ser hablantes nativos de la lengua del intercambio virtual. También llevamos a cabo un proyecto de comunicación asincrónica con alumnos de Medicina de una universidad brasileña -UNILA, de Foz de Iguazú. La especificidad disciplinar de la carrera brasileña participante fue atendida desde lo histórico. Así, los estudiantes argentinos de Historia y su profesora confeccionaron un 
texto para el intercambio (GARCÍA; POZZO, 2015b), también centrado en la provincia de Santa Fe, y filmaron su relato oral. Una vez subido a internet, este pudo ser visitado por los estudiantes brasileños de medicina.

Para estos proyectos que se valieron de las posibilidades que ofrecen las TICs, realizamos un diagnóstico de las habilidades tecnológicas de los estudiantes del profesorado de Historia (JACOB; POZZO, 2015b). Si bien se trata de un grupo joven (promedian los 22 años), dieron prueba del desconocimiento de algunas herramientas tecnológicas básicas para la implementación de proyectos mediados por las TICs (tales como skype o power point), lo cual nos implicó dedicar un tiempo previo a su familiarización.

Del Profesorado de Historia elegimos el Seminario de Historia regional por dos razones: por el carácter aglutinante de este campo de estudio que involucra tanto contenidos disciplinares como elementos identitarios, y en tanto la historia latinoamericana es parte de la currícula de las carreras de español como lengua extranjera. En las sesiones de telecolaboración con las instituciones europeas, los profesores en formación debían transmitir la propia cultura a estudiantes extranjeros según un plan cuidadosamente estipulado.

Todos estos proyectos fueron evaluados por sus protagonistas, así como por los docentes-investigadores a cargo según un sistema operacional de indicadores de la CCI. Los resultados obtenidos fueron socializados en diversos eventos y publicaciones académicas (POZZO; 2015b; POZZO et al., 2015). Las producciones contribuyen a superar la vacancia señalada por YOUNG y SACHDEV (2011, p.81), quienes resaltan los escasos estudios empíricos sobre cómo se llevan a la práctica los enfoques 
interculturales, relegados por estudios teóricos o de naturaleza retórica.

En una fase de aplicación, y en vistas a dotar a los resultados de un impacto en el plano didáctico, construimos materiales didácticos en formato audiovisual para la enseñanza de historia argentina y latinoamericana. Esto es, en esta instancia ya capitalizamos las experiencias previas pero nos focalizamos más en el producto que en el proceso. La propuesta de hacer audiovisuales de historia latinoamericana y argentina responde a la vacancia que detectamos en este soporte, así como la escasa presencia de Latinoamérica como contenido de los libros de español como lengua extranjera que relevamos en estudios previos (POZZO, 2014). Al mismo tiempo, percibíamos al interés que esta región del planeta está teniendo en diversas universidades de países no hispanohablantes. Las lecciones en videos están concebidas para estudiantes extranjeros, en cuanto a la explicitación de referentes culturales, pero resultan aplicables también a población nativa por su claridad explicativa. Estos cubren los siguientes recortes espacio-temporales y temáticos:

- El contexto internacional, siglo XIX: “El largo y tumultuoso siglo XIX";

- América Latina, siglo XIX: "América o las Américas";

- América Latina, siglo XX: "América Latina en el siglo XX. Revoluciones y contra-revoluciones";

- Argentina 1880-1912: “La consolidación del Estado nacional argentino". 
Todos los videos se encuentran disponibles gratuitamente en el sitio web del proyecto ya indicado. La selección de contenidos para su tratamiento comprimido en una duración no mayor a quince minutos es el principal desafío para los guionistas. Por ellos, los criterios históricos y educativos de la realización audiovisual ameritan una producción propia tendiente a explicitar los fundamentos. Así, los tres primeros videos, abocados cada uno de ellos a cien años de historia, nada menos, se encuentran desarrollados en: POZZO; BESSO PIANETTO; DONATO, 2015; BESSO PIANETTO; POZZO, 2014; POZZO; BESSO PIANETTO, 2016, respectivamente. Por su parte, el aprovechamiento didáctico probado con estudiantes italianos puede ser consultado en THEINER, 2015. Las actividades basadas en el recurso audiovisual pueden ser transferidas a una plataforma académico-institucional, tarea que plantea cuestiones teóricas y metodológicas al docente (AMEZ, 2015b) atendiendo a las peculiaridades contextuales.

La atención a los aspectos metodológicos inherentes al diseño de proyectos (FANDINO CUBILLOS, 2007) permite contribuir a nuevas implementaciones tanto propias como ajenas. Por otra parte, optar por proyectos interculturales es una posibilidad para todos aquellos docentes que deseen innovar sus prácticas apelando a la naturaleza misma de la sociedad actual. Es con dicha intención que este capítulo se integra al presente libro, como una invitación constantemente abierta a sus lectores y con un presente de vínculos interinstitucionales encaminados a robustecer la formación docente en el mundo. 


\section{REFERENCIAS}

AMEZ, Mariel. La presencia de estudiantes extranjeros en el nivel superior argentino. Un estudio de caso centrado en el Instituto de Educación Superior $N^{\circ} 28$ "Olga Cossettini" de Rosario. En POZZO, María Isabel (ed.) Construcción de espacios interculturales en la formación docente: competencia comunicativa intercultural, cultura regional y TIC, p.71-84. Rosario: Laborde Editor. 2015a. ISBN 978-987-677-109-2.

AMEZ, Mariel. Construcción de materiales didácticos mediados por TIC: consideraciones teóricas y decisiones preliminares. En POZZO, María Isabel (ed.) Construcción de espacios interculturales en la formación docente: competencia comunicativa intercultural, cultura regional y TIC, p.245-254. Rosario: Laborde Editor. 2015b. ISBN 978-987-677-109-2.

BÉRODOT, Solène; POZZO, María Isabel. Las TIC en la clase de lengua extranjera. Un proyecto de coacción entre docentes argentinos en formación y estudiantes franceses de escuela media. En POZZO, María Isabel (ed.) Construcción de espacios interculturales en la formación docente: competencia comunicativa intercultural, cultura regional y TIC, p.191-202. 2015. Rosario: Laborde Editor. ISBN 978-987-677-109-2.

BESSO PIANETTO, María Elena; POZZO, María Isabel. Reflexiones teórico-metodológicas para la realización de un audiovisual educativo sobre América Latina. Revista Anuario Americanista Europeo, n.12, p.71-86. ISSN 22213872. Consejo Europeo de Investigaciones Sociales de 
América Latina. Disponible en: http://www.red-redial. net/revista/anuario-americanista-europeo/article/viewFile/278/276. 2014.

BYRAM, Michael. Teaching and assesing intercultural communicative competence. Clevedon: Multilingual Matters, 1997.

CONSEJO DE EUROPA (2001). Marco Común Europeo de Referencia para las lenguas: aprendizaje, enseñanza, evaluación. Traducido al español por el Instituto Cervantes. Madrid: Anaya, 2001.

DÍAZ, Rubén; ALONSO, Graciela. Construcción de espacios interculturales. Buenos Aires: Miño y Dávila, 2004.

FANDIÑO CUBILLOS, Graciela. El pensamiento del profesor sobre la planificación en el trabajo por proyectos. Bogotá: Universidad Pedagógica Nacional, 2007.

FERNÁNDEZ, Marcela; DAVANTURE, Adriana. La contextualización como eje del enfoque intercutural-multicultural. Experiencias de profesores de francés. En POZZO, María Isabel (ed.) Construcción de espacios interculturales en la formación docente: competencia comunicativa intercultural, cultura regional y TIC, p.121-130. Rosario: Laborde Editor, 2015. ISBN 978-987-677-109-2.

FERNÁNDEZ, Susana Silvia; POZZO, María Isabel. La telecolaboración como herramienta para la enseñanza/ aprendizaje de la historia regional argentina en Dinamarca: un proyecto de intervención didáctica. En POZZO María Isabel (ed.) Construcción de espacios interculturales 
en la formación docente: competencia comunicativa intercultural, cultura regional y TIC, p.155-180. Rosario: Laborde Editor, 2015. ISBN 978-987-677-109-2.

GARCÍA, Lía; POZZO, María Isabel. Santa Fe: territorio de los primeros enclaves coloniales tras la conquista. En POZZO, María Isabel (ed.) Construcción de espacios interculturales en la formación docente: competencia comunicativa intercultural, cultura regional y TIC, p.181-190. Rosario: Laborde Editor, 2015a. ISBN 978-987-677-109-2.

GARCÍA, Lía Claudia; POZZO, María Isabel. Salud y enfermedad en la ciudad de Rosario. Un abordaje histórico para estudiantes brasileños de español de la carrera de Medicina. En POZZO, María Isabel (ed.) Construcción de espacios interculturales en la formación docente: competencia comunicativa intercultural, cultura regional y TIC, p.203-220. Rosario: Laborde Editor, 2015b. ISBN 978-987-677-109-2.

PAROLA, Gilda. La formación inicial docente: momento clave para el desarrollo de la competencia comunicativa intercultural. En POZZO, María Isabel (ed.) Construcción de espacios interculturales en la formación docente: competencia comunicativa intercultural, cultura regional y TIC, p.99-120. Rosario: Laborde Editor, 2015. ISBN 978-987-677-109-2.

POLO, María del Pilar. Postales musicales de la ciudad de Rosario: un aporte desde el Área Estético-Expresiva a la construcción de competencias comunicativas interculturales en la Formación Docente. En POZZO, María Isabel (ed.) Construcción de espacios interculturales en la 
formación docente: competencia comunicativa intercultural, cultura regional y TIC, p.273-284. Rosario: Laborde Editor, 2015. ISBN 978-987-677-109-2.

POZZO, María Isabel (Ed.). Migraciones y formación docente. Aportes para una educación intercultural. Berlín: Peter Lang, 2009. ISBN: 978-3-0343-0068-1.

POZZO, María Isabel. Contenidos socioculturales sobre América Latina en manuales de español lengua extranjera de España y Argentina. Revista SURES, v.3, p.1-15. Universidad Federal de la Integración Latinoamericana. Foz de Iguazú, 2014. Disponible en: https:/ / revistas.unila. edu.br/index.php/sures/article/viewFile/146/116.

POZZO, María Isabel. Construcción de espacios interculturales en educación. Hacia el diseño e implementación de proyectos en la formación docente. En POZZO, María Isabel (ed.) Construcción de espacios interculturales en la formación docente: competencia comunicativa intercultural, cultura regional y TIC, p.17-36. Rosario: Laborde Editor, 2015a. ISBN 978-987-677-109-2.

POZZO, María Isabel. Construcción de espacios interculturales en la educación superior: competencia comunicativa intercultural, cultura regional y TIC. Foro Internacional Investigación y Políticas Públicas para la Educación. Universidad Nacional del Litoral y Ministerio de Educación de la pcia.de Santa Fe, 2015b.

POZZO, María Isabel (ed.). Construcción de espacios interculturales en la formación docente: competencia comunicativa intercultural, cultura regional y 
TIC, p. 285-306. Rosario: Laborde Editor, 2015. ISBN 978-987-677-109-2.

POZZO, María Isabel; AMEZ, Mariel; BESSO PIANETTO, María Elena et al. Diseño e implementación de proyectos interculturales como estrategia de formación de profesionales reflexivos. XII Jornada de Reflexión y Socialización del Trayecto de la Práctica: La Formación del Profesional Reflexivo. Instituto de Educación Superior N $\mathrm{N}^{\circ} 28$ “Olga Cossettini" de Rosário, 2015.

POZZO, María Isabel; BERTRAMO, Brenda; D' ASCANIO, Gabriela. La movilidad académica en la educación superior no universitaria argentina. Programas estatales y perspectivas de los actores. En POZZO María Isabel (ed.) Construcción de espacios interculturales en la formación docente: competencia comunicativa intercultural, cultura regional y TIC, p.85-98. Rosario: Laborde Editor, 2015. ISBN 978-987-677-109-2.

POZZO, María Isabel; BESSO PIANETTO, María Elena. Reflexiones históricas para el diseño de un audiovisual educativo sobre América Latina-siglo XX. Revista Culturas. Debates y perspectivas de un mundo en cambio, v.10. Facultad de Humanidades y Ciencias de la Universidad Nacional del Litoral. En prensa, 2016.

POZZO, María Isabel; BESSO PIANETTO, María Elena; DONATO, María del Carmen. Enseñar historia argentina a extranjeros a través de audiovisuales: desafíos y propuestas. En POZZO María Isabel (ed.) Construcción de espacios interculturales en la formación docente: competencia comunicativa intercultural, cultura regional 
y TIC, p.221 a 244. Rosario: Laborde Editor, 2015. ISBN 978-987-677-109-2.

POZZO,MaríaIsabel;D'ASCANIO,Gabriela;BERTRAMO, Brenda. La formación didáctica en el Profesorado de Historia del Instituto de Educación Superior $N^{\circ} 28$ Olga Cossettini. Análisis curricular. En POZZO María Isabel (ed.) Construcción de espacios interculturales en la formación docente: competencia comunicativa intercultural, cultura regional y TIC, p.131-144. Rosario: Laborde Editor, 2015. ISBN 978-987-677-109-2.

POZZO, María Isabel; JACOB, Carolina. Diversidad cultural en la escuela secundaria argentina. Perfil de los estudiantes de intercambio 2014. En POZZO María Isabel (ed.) Construcción de espacios interculturales en la formación docente: competencia comunicativa intercultural, cultura regional y TIC, p.285-306. Rosario: Laborde Editor, 2015a. ISBN 978-987-677-109-2.

POZZO María Isabel; JACOB, Carolina. Mitos y realidades sobre el uso de TIC en estudiantes de nivel superior. Perfil tecnológico de estudiantes de la carrera Historia del gran Rosario. En POZZO, María Isabel (ed.) Construcción de espacios interculturales en la formación docente: competencia comunicativa intercultural, cultura regional y TIC, p.145-154. Rosario: Laborde Editor, 2015b. ISBN 978-987-677-109-2.

POZZO, María Isabel; PIDELLO, María Amelia. La formación docente desde el enfoque por competencias. El aporte de la competencia comunicativa intercultural. En POZZO, María Isabel (ed.) Construcción de espacios 
interculturales en la formación docente: competencia comunicativa intercultural, cultura regional y TIC, p.3756. Rosario: Laborde Editor, 2015. ISBN 978-987-677-109-2.

POZZO, María Isabel; VIRGOLÍN, Natalia. La movilidad académica estudiantil como objeto de estudio. Antecedentes y estado de la cuestión. En POZZO, María Isabel (ed.) Construcción de espacios interculturales en la formación docente: competencia comunicativa intercultural, cultura regional y TIC, p.57-70. Rosario: Laborde Editor, 2015. ISBN 978-987-677-109-2.

RITACCO REAL, Maximiliano. Prólogo. En POZZO, María Isabel (ed.) Construcción de espacios interculturales en la formación docente: competencia comunicativa intercultural, cultura regional y TIC, p.9-16. Rosario: Laborde Editor, 2015. ISBN 978-987-677-109-2.

THEINER, Irene. La didactización de audiovisuales através del enfoque integrado de contenidos y lengua (EICLE). Propuestas para estudiantes de español lengua extranjera. En POZZO, María Isabel (ed.) Construcción de espacios interculturales en la formación docente: competencia comunicativa intercultural, cultura regional y TIC, p.255-272. Rosario: Laborde Editor, 2015. ISBN 978-987-677-109-2.

THEINER, Irene; POZZO, María Isabel. Competencia comunicativa intercultural y enfoque integrador de historia y lengua. Un proyecto en educación superior. Actas de las XV Jornadas y II Congreso Latinoamericano de Enseñanza de Lenguas Extranjeras en el Nivel Superior. Lenguas y Culturas: desafíos actuales de la diversidad 
y de la integración. Facultad de Lenguas, Universidad Nacional de Córdoba. En prensa, 2015.

YOUNG, Tony; SACHDEV, Itesh. Intercultural communicative competence: exploring English language beliefs and practices. Language awareness, v.20, n.2, p.81-98. 2011. 


\section{EL RETO DE LA EDUCACIÓN DIGITAL: más allá de la transformación metodológica}

Rosa Ana Martín Vegas (USAL)

La educación digital se extiende de forma natural como consecuencia de la expansión de las tecnologías de la información y de la comunicación (TIC) y su impacto social. El debate sobre si la incorporación de las TIC a las aulas es una necesidad educativa o una cuestión de esnobismo está ya fuera de duda, pues claramente la escuela no puede estar de espaldas a la sociedad y no puede desaprovechar los flujos de información que parten de una fuente ingente, de máxima actualidad y de mayor accesibilidad para todos como es internet. En este artículo plantearemos los cambios requeridos para la eficacia de este nuevo modelo de metodología formativa a partir del análisis de las deficiencias en su implantación actual, heredadas, en gran medida, de la inercia de un modelo educativo tradicional y difícil de superar.

\section{¿Por qué es necesaria una revolución educativa?}

Se habla de altos índices de fracaso escolar, de desmotivación y desinterés por parte de los alumnos, de ineficacia del sistema y, en general, de un sistema educativo que 
no forma a ciudadanos preparados para el mundo laboral y la vida comunitaria real. Esta crítica profundamente arraigada en la educación española, en gran parte de la europea y en la del continente iberoamericano procede, por un lado, de la idea negativa muy extendida de que el sistema actual no funciona, y reclama, por otro lado, innovación; algo no funciona y hay que cambiarlo. En España, cada gobierno de turno ha realizado una reforma educativa siempre contando con la oposición de gran parte de la comunidad educativa. Finalmente, dichas reformas no se han llevado a cabo en su totalidad, bien porque el espíritu ideológico de la ley no ha llegado a la práctica del aula (la LOGSE de 1990, por ejemplo) o bien porque la plena implantación se ha obstruido con cambios políticos. Este deseo de cambios en el sistema educativo es un hecho derivado de que lo que hay no funciona bien y del deseo de innovar, que es una necesidad educativa de primer orden. Y es aquí de donde parte nuestra reflexión.

¿Tan malo es el sistema actual? ¿Es malo porque hay alumnos que no llegan a obtener la aptitud de los estudios obligatorios, porque los alumnos que certifican están muy mal preparados o por las dos cosas? ¿Por qué los alumnos están mal preparados? ¿Porque no saben nada, porque no saben hacer nada, porque lo que les han enseñado no les sirve para nada...? ¿Cuáles son las razones de que el sistema no funcione? ¿Los profesores, la actitud de los alumnos ante la escuela, la falta de prestigio social del colegio, los recursos que se utilizan para aprender o la falta de medios económicos en algunos casos? Podríamos continuar con más preguntas sobre qué es lo que pasa para justificar la necesidad de cambios, pero, probablemente, ni todo lo que hay es malo y debe liquidarse, ni se deba 
plantear la innovación como la erradicación de lo existente, sino como un proceso de mejora y de adaptación a la vida.

Son muchos los artículos escritos por distintas autoridades en el ámbito educativo que discuten el origen del mal y promulgan la revolución educativa. Centran su atención en aspectos como que la educación no tiene conexión con el mundo real, cuestión causante de la desmotivación del alumnado, que no tiene interés por aprender lo que no tiene una utilidad inmediata. Afirmaciones de este tipo carecen de absoluta veracidad, pues en la escuela se enseña a conocer el mundo en sus múltiples facetas imposibles de experimentar de forma individual. El problema de parte de este desinterés del alumnado no reside en los conocimientos que se enseñan sino en cómo se enseñan. $Y$ el cómo va mucho más allá de los recursos utilizados que discutiremos más adelante. Se trata de enseñar de manera transversal, relacionando contenidos, ideas, emociones, experiencias... para mostrar a los escolares la conectividad del mundo real con sus complejos nódulos estructurales. De esta forma, cada individuo podrá ver y disfrutar de la utilidad del conocimiento, porque un aprendizaje redundará en otro y este a su vez en otro que cada alumno podrá aplicar a sus propios intereses.

El DRAE define la palabra revolución como un "cambio rápido y profundo en cualquier cosa". La revolución educativa tal y como la vamos a concebir en este estudio no puede ser rápida, pues va más allá del cambio instrumental que supone la introducción de las TIC, pero sí es profunda, porque exige cambios en el planteamiento metodológico que requieren un profunda formación conceptual en el dominio de cada materia por parte del profesorado y una transformación en los hábitos de transmisión 
que permitan el feedback del alumno para que procese e interiorice su aprendizaje.

\section{Métodos revolucionarios de la escuela actual}

Esta supuesta revolución que hay que llevar a cabo en el sistema educativo se ha etiquetado con el término innovación. La acción de innovar, introducir novedades, debe existir en la enseñanza de cualquier materia siempre, cada día, cada curso... Trabajar con personas exige la continua adaptación a las capacidades intelectuales, perceptivas, físicas, sociales y personales de cada individuo. No es posible en educación seguir la misma pauta con alumnos pertenecientes a distintas generaciones, edades, niveles y capacidades. Por eso, siempre hay que innovar, siempre que buscar métodos de acercamiento a los distintos discentes y grupos para desarrollar sus facultades intelectuales y morales, así como para enseñarles los buenos usos de urbanidad y cortesía -como define la palabra educación el DRAE-, que deben contextualizarse en cada sociedad y acto de convivencia. Por tanto, innovación no es sinónimo de educación digital, pues se puede innovar usando los llamados recursos tradicionales. Innovación implica cambio metodológico, adaptación a las capacidades y necesidades del alumno con el fin de que logre el aprendizaje. El cambio metodológico es motivador, pues despierta la atención de los alumnos ante lo nuevo. Por eso, no siempre es innovación el uso de las TIC; se puede ser muy innovador utilizando recursos de muy distinta tipología.

La innovación educativa se ha centrado en los recursos metodológicos. Casanova y Bazarra (2016) señalan distintos métodos como revolucionarios en la escuela actual: 
1) el aprendizaje basado en proyectos: desarrollar un proyecto para dar solución a un problema real implicando a varias asignaturas; 2) la gamificación: usar mecánicas de juego para desarrollar habilidades; como en los videojuegos, hay retos, avatares, fases y niveles; 3 ) la flipped classroom (la clase al revés): las lecciones que se escuchaban en el aula ahora se oyen en casa mediante grabaciones y los deberes que tradicionalmente se hacen en casa, ahora se hacen en la clase mediante trabajo en equipo; 4) el design thinking: el alumno piensa como un diseñador y debe seguir los pasos de empatizar, definir el problema, idear, aplicar y evaluar; 5) el design for change: se llama aprendizaje servicio porque se trata de que los alumnos hagan un servicio a su comunidad para aprender a colaborar y desarrollar la conciencia social; por ejemplo, los alumnos del instituto de Sils (Gerona, España) acuden al geriátrico del municipio; 6) el aprendizaje cooperativo: trabajar en grupos pequeños y aprovechar las capacidades y conocimientos de cada miembro; y 7) el aprendizaje basado en problemas: los alumnos deben estudiar un problema para resolverlo y deben concurrir conocimientos de varias asignaturas.

¿Son realmente estos métodos revolucionarios? Muchos de ellos son antiquísimos y otros, aunque sin la misma denominación, se llevan a cabo en algunas aulas desde hace décadas. Sin embargo, sí son revolucionarios porque no son populares, es decir, no se aplican en la gran mayoría de las escuelas y responden a una manera de trabajar que no es la frecuente en los sistemas educativos de la mayor parte de los países. Al margen de la etiquetación de las estrategias metodológicas, comparten ciertos rasgos que rompen con la estructura tradicional de las clases (cuadro 1). 
Cuadro 1 - metodología educativa tradicional vs. metodología "innovadora" actual

\begin{tabular}{|l|l|}
\hline \multicolumn{1}{|c|}{ clase tradicional } & \multicolumn{1}{c|}{ clase "innovadora"1 } \\
\hline $\begin{array}{l}\text { clase magistral: el profesor } \\
\text { explica, los alumnos escuchan y } \\
\text { pueden tomar notas }\end{array}$ & $\begin{array}{l}\text { trabajo por proyectos (distintas } \\
\text { modalidades): el profesor pauta } \\
\text { una guía de trabajo y los alumnos } \\
\text { adquieren conocimientos y } \\
\text { desarrollan habilidades por sí mismos }\end{array}$ \\
\hline $\begin{array}{l}\text { los contenidos se definen por } \\
\text { materias }\end{array}$ & $\begin{array}{l}\text { los contenidos son transversales, } \\
\text { implican a varias áreas de } \\
\text { conocimiento y consienten una } \\
\text { comprensión global e integradora }\end{array}$ \\
\hline $\begin{array}{l}\text { trabajo individual: los alumnos } \\
\text { realizan ejercicios para procesar } \\
\text { toda la información recibida en la } \\
\text { clase magistral }\end{array}$ & $\begin{array}{l}\text { trabajo cooperativo y en grupo: los } \\
\text { alumnos exploran los contenidos, } \\
\text { los procesan y resuelven en } \\
\text { colaboración, compartiendo el } \\
\text { aprendizaje en el grupo }\end{array}$ \\
\hline $\begin{array}{l}\text { recursos: libros de texto y fichas } \\
\text { con ejercicios }\end{array}$ & $\begin{array}{l}\text { recursos: libros, revistas, } \\
\text { periódicos, blogs, bases de datos...; } \\
\text { materiales digitales en red }\end{array}$ \\
\hline $\begin{array}{l}\text { evaluación: a través de exámenes } \\
\text { y pruebas individuales se } \\
\text { comprueba si los alumnos han } \\
\text { asimilado los conocimientos } \\
\text { enseñados }\end{array}$ & $\begin{array}{l}\text { autoevaluación y coevaluación: } \\
\text { se evalúa no solo resultados, } \\
\text { también el proceso y el progreso } \\
\text { de aprendizaje con autocrítica } \\
\text { (individual y de grupo) para que } \\
\text { los escolares sean más conscientes } \\
\text { de su desarrollo }\end{array}$ \\
\hline
\end{tabular}

Fuente: Rosa Ana Martín Vegas.

Se habla de hasta veinte retos para la educación del futuro (PÉREZ-BARCO, 2013): formar al ciudadano del

1 Clase "innovadora", entrecomillado, porque realmente la enseñanza siempre debe ser innovadora, y la innovación, pese a utilizarse ahora como sinónimo de modernidad y de uso de recursos nuevos, ha existido siempre en cada época. 
siglo XXI, centrar la inclusión social como eje, buscar el liderazgo internacional, extraer la inteligencia colectiva, ligar conocimientos, pedagogía y tecnología, implicar nuevos métodos de evaluación con las TIC, romper el mito de los nativos digitales, ${ }^{2}$ fomentar la creatividad, valorar la educación emocional, conseguir la cooperación entre la familia, la escuela y la comunidad, centrar el liderazgo en la pedagogía y no en la burocracia, tener presente que el objetivo es siempre el desarrollo de competencias, focalizar la enseñanza en los intereses del aprendiz, reconfigurar la formación y el rol del profesor, alcanzar la ecología del aprendizaje, ${ }^{3}$ considerar todos los ámbitos educativos posibles, interactuar sobre los contenidos, ${ }^{4}$ encontrar una formación adaptada a las demandas, formar a ciudadanos y no solo a profesionales eficientes y evitar la ansiedad tecnológica. ${ }^{5}$

Todos estos retos de la educación del siglo XXI son grandes ideas desarrolladas por distintos especialistas en conferencias y artículos que podemos encontrar registrados en internet. Aquí nos interesa valorar aquellos en los que más directamente interviene la educación digital,

2 Se refiere a la idea de que las nuevas generaciones dominan las TIC y no necesitan formación en este terreno. Esta idea es falsa.

3 Sería conseguir que el aprendizaje redundase en las relaciones de los seres y con el medio en que viven.

4 El aprendizaje no reside en los contenidos sino en las interacciones que se producen en torno a ellos. Es decir, se deben poner en práctica los conocimientos y es aquí donde el alumno interviene agregando, modificando, criticando, reflexionando...; eso es interactuar y procesar un aprendizaje.

5 Los avances tecnológicos son rápidos y la educación tiene que usar los recursos del momento y aprovecharlos de forma rentable sin crear alumnos impacientes, inestables y ansiosos. 
que es el gran reto actual de la escuela debido al poder de la red como fuente de conocimiento y comunicación. La introducción de internet en las aulas es la parte instrumental más aparente de la metodología didáctica emergente.

\section{La educación digital}

Todos los supuestos retos de la educación del siglo XXI son consecuencia (aunque no exclusivamente) del desarrollo del mundo digital, que ha ampliado enormemente las fuentes de información y la manera de comunicarse. De los retos expuestos en el apartado anterior, el cuadro 2 recoge y explica aquellos intrínsecamente relacionados con la formación digital.

Cuadro 2 - Cómo influye la educación digital

\begin{tabular}{|l|l|}
\hline \multicolumn{2}{|c|}{ la educación digital } \\
\hline formar al ciudadano del siglo XXI & $\begin{array}{l}\text { para que sea competente con el } \\
\text { mundo digital }\end{array}$ \\
\hline extraer la inteligencia colectiva & $\begin{array}{l}\text { aprovechar las posibilidades } \\
\text { abiertas y múltiples de la sociedad } \\
\text { digital }\end{array}$ \\
\hline contenidos + pedagogía + & $\begin{array}{l}\text { la tecnología amplía las } \\
\text { posibilidades de la pedagogía } \\
\text { porque permite conocer mejor } \\
\text { tecnología }\end{array}$ \\
$\begin{array}{l}\text { y más y permite desarrollar el } \\
\text { aprendizaje significativo o por } \\
\text { descubrimiento del alumno } \\
\text { (el alumno como investigador } \\
\text { protagonista de su aprendizaje) }\end{array}$ \\
\hline
\end{tabular}




\section{la educación digital}

\begin{tabular}{|l|l|}
\hline $\begin{array}{l}\text { las TIC implican nuevos métodos } \\
\text { de evaluación }\end{array}$ & $\begin{array}{l}\text { no se evalúan solo contenidos sino } \\
\text { también la habilidad de adquirir y } \\
\text { poner en práctica esos contenidos }\end{array}$ \\
\hline $\begin{array}{l}\text { objetivo: desarrollo de } \\
\text { competencias }\end{array}$ & $\begin{array}{l}\text { las TIC permiten desarrollar el } \\
\text { trabajo autónomo, la capacidad } \\
\text { de investigación, el tratamiento } \\
\text { de la información, el trabajo } \\
\text { colaborativo, la comunicación... }\end{array}$ \\
\hline nuevo rol del profesor y su & $\begin{array}{l}\text { el profesor pasa a ser un guía } \\
\text { en el proceso de aprendizaje } \\
\text { y debe conocer perfectamente } \\
\text { formación }\end{array}$ \\
$\begin{array}{l}\text { los recursos que ayudarán al } \\
\text { alumno a conseguir su objetivo de } \\
\text { aprendizaje; por eso, debe tener } \\
\text { muchos conocimientos teóricos } \\
\text { y también prácticos, dominar la } \\
\text { fuentes de información y los flujos } \\
\text { y estrategias de búsquedas }\end{array}$ \\
\hline interacción sobre los contenidos & $\begin{array}{l}\text { el trabajo en red, con muchos } \\
\text { puntos de información y crítica, } \\
\text { permite al alumno pensar e } \\
\text { interactuar ante los problemas o } \\
\text { contenidos, pues debe, a partir de } \\
\text { varias fuentes, elaborar su propio } \\
\text { contenido en un ejercicio de } \\
\text { síntesis, abstracción, contraste... }\end{array}$ \\
\hline
\end{tabular}

Fuente: Rosa Ana Martín Vegas.

De este modo, se puede concluir (figura 1), que la educación digital resulta ser fundamental para el desarrollo de los principios del aprendizaje deseable. 
Figura 1 - presupuestos implicados en la educación digital

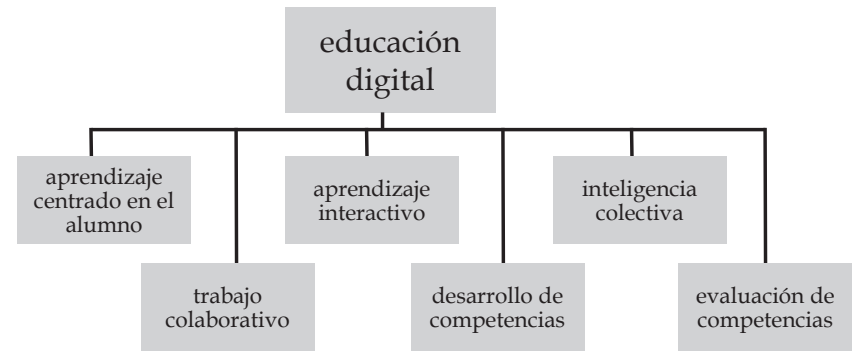

Fuente: Rosa Ana Martín Vegas.

La implantación de una educación digital ha supuesto muchos problemas, lo que indica que, pese a ser algo natural porque las nuevas tecnologías están totalmente instauradas en nuestra sociedad, la escuela es reticente. En principio se habló de la falta de apoyo y financiación por parte de las administraciones y de la falta de preparación de los docentes. Miller (2016) añade a la resistencia al cambio y a la formación del profesorado, las propias dificultades que implica el aprendizaje que exige una participación muy activa del alumno y el mismo aprendizaje personalizado. La mayeútica ${ }^{6}$ es complicada como método, pues exige inteligencia y habilidad por parte del profesor y también por parte del alumno, cuya disposición no siempre es favorable. Sin duda la metodología es tan compleja como enriquecedora.

Otra cuestión ligada a la educación digital ha sido la proliferación de cursos en línea. Pensando en la libertad

6 Método socrático de enseñanza que consiste en hacer descubrir los conocimientos al alumno a través de preguntas. 
que estos cursos dan al estudiante, muchas entidades y universidades han desarrollado cursos no presenciales. Pardo (2016) considera que la autonomía que ofrece el trabajar en línea da una flexibilidad muy agradecida por estudiantes y profesores. A su vez, el contacto más personal con el alumno parece una ventaja, pues se acercaría a la enseñanza más personalizada. Sin embargo, no es exactamente así porque las tutorías acercan las relaciones personales pero no personalizan el trabajo, pues los materiales sirven al gran grupo y las tareas y objetivos planteados son igual para todos. El contacto profesor-alumno en tutorías telemáticas puede ser bueno pero no mejor que el existente en una tutoría presencial. Corbalán (2001) habla de los problemas de la enseñanza en línea en Estados Unidos hace más de una década. Pues bien, los mismos problemas se mantienen hoy: mayor deserción en los cursos en línea que en los presenciales y dificultades a la hora de evaluar (exámenes tipo test en su mayoría, que evalúan más conocimientos que capacidades). A estas ideas, se debe añadir otra fundamental: los materiales de estos cursos son un calco a los libros de texto tradicionales; varía la conexión hipertextual que permiten los textos web y el diseño de opcionalidad de los ejercicios, que está limitado por los sistemas de corrección automática. Algo fundamental tiene que cambiar en la educación digital: el planteamiento metodológico y el uso de las fuentes de información, que no pueden exponerse como libros de textos, idénticos en formulación y metodología a los libros en papel pero en formato digital. 


\section{Libro de texto vs. trabajo por proyectos}

La difusión de materiales educativos digitales en estos últimos años no ha supuesto un gran cambio pedagógico respecto al uso de los libros de texto en papel como principal recurso para la enseñanza-aprendizaje en todas las materias. Los materiales digitales publicados son exactos a los libros de texto tradicionales, solo cambia el formato. Esta es la razón por la que no han supuesto más cambio en el planteamiento educativo que el puramente formal: en vez de leer en papel, se lee en pantalla y en vez de resolver los ejercicios en un cuaderno, se resuelven de forma digital, con poco texto escrito y mucho enlace o cliqueado. El gran cambio metodológico que no se ha llevado a cabo, al menos de manera extensiva, vendría de la mano de los llamados trabajos por proyectos.

Penalva (2016) señala el abandono del libro de texto como el paso esencial para conseguir un cambio en la educación. Considera el libro de texto clásico una herramienta obsoleta porque resume conocimientos aislados, sin contextualización y sin criterio de selección, pues no responden a las experiencias previas del alumno $\mathrm{ni}$ a sus motivaciones e intereses. Las limitaciones del libro de texto se deben a su formato, pues deben incluir conocimientos concretos según un programa educativo de orden ministerial. Por el contrario, el formato web, dadas las posibilidades de hipervincular textos, permite el acceso a conocimientos globales, de carácter más universal, pues la información puede ampliarse hasta donde se desee o necesite. Los materiales de internet son más plurales, pueden adaptarse mejor al contexto y al nivel 
de los alumnos y, sin duda, necesitan de la intervención activa del alumno para construir su aprendizaje. Nacen, de este modo, los trabajos por proyectos, que son planteamientos basados en temas de actualidad que deben desarrollarse buscando información en internet integrando conocimientos diversos y buscando un fin práctico que sea de interés para los alumnos. Estos proyectos didácticos están definidos en su planteamiento y guía de trabajo pero no en su desarrollo, pues cada estudiante, en función de sus posibilidades y sus intereses, moldeará su proyecto en función de unos fines. La selección de información es fundamental para el cauce que ha de seguir el proyecto, pero capacidades como la abstracción, la deducción y la inducción, así como la creatividad, desarrollan en cada caso proyectos personalizados distintos donde los alumnos son los auténticos protagonistas como participantes en la elaboración del trabajo y el procesamiento de la información. Es así como se produce el auténtico aprendizaje consciente. Esta metodología de trabajo que tiene como principal recurso internet, supone un verdadero cambio en el proceso educativo (ver figura 2). Y este cambio va más allá del uso de las TIC, porque no se trata de realizar actividades en formato digital, sino de procesar información para solucionar problemas o cuestiones de interés a partir de recursos digitales, que no son más que una fuente de información ingente por la cantidad de datos objetivos y subjetivos que pueden substraerse. 
Figura 2 - Aspectos metodológicos del trabajo por proyectos

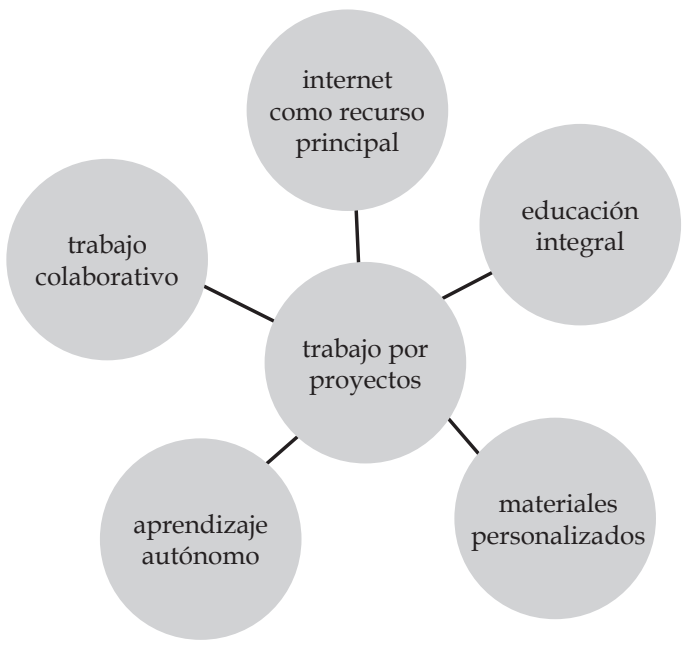

Fuente: Rosa Ana Martín Vegas.

La educación integral supone una transformación porque rompe con los conocimientos estancos, con la estructuración de asignaturas sin relación directa entre ellas; es una educación transversal. Por otra parte, relaciona aprendizaje conceptual, con procedimental y actitudinal, es decir, se relacionan conocimientos, con competencias y habilidades y con valores. Para elaborar este tipo de proyectos y poder trabajar en el aula con esta metodología, es imprescindible la labor del profesor, que necesita tener una buena formación en todos los sentidos, ser muy hábil en el proceso de comunicación y tener una buena disposición para trabajar mucho más de lo que supone la clase tradicional guiada por el libro de texto. Los proyectos exigen crear materiales de elaboración propia, pues la actualización de contenidos y la personalización adaptada 
al contexto requiere un esquema de trabajo previo muy estudiado y planificado. Este inmenso trabajo explica el éxito de los libros de texto, que facilitan al docente toda la labor educativa e incluso formativa, en muchos casos.

Los trabajos por proyectos tienen como principal fuente de información internet, la gran red de datos interconectados. Sin embargo, no todo está en internet. Los libros siguen siendo una fuente de información imprescindible; ${ }^{7}$ de este modo, las bibliotecas convencionales son centros de recursos fundamentales para la elaboración de los proyectos. ${ }^{8}$ Asimismo, todos los espacios sociales que puedan incorporarse al proyecto, así como todas las manifestaciones expresivas (escribir, hablar, grabar, actual, dibujar, cantar...) son parte de la idea de transversalidad y globalidad. ${ }^{9}$

$7 \quad$ El mismo libro de texto pasaría a ser un recurso más, no el único recurso, como se viene haciendo habitualmente. El rechazo principal al libro de texto viene dado porque fomenta un aprendizaje memorístico, exclusivamente basado en la transmisión de conocimientos y no en el desarrollo de competencias y destrezas.

8 En Martín Vegas (2014) se exponen las bases para el uso de la biblioteca escolar como un centro de investigación para el desarrollo de trabajo por proyectos.

9 En la cultura hispánica las salidas de los escolares del centro educativo son puntuales (excursiones esporádicas); sin embargo, en otras culturas como la germánica es más frecuente que los alumnos salgan del centro para ir a aprender matemáticas al mercado o ver insectos en el bosque cercano. La formación que implique, además del contacto con la vida real, servicios comunitarios (como puede ser ayudar a compañeros con discapacidades, hacer tareas de jardinería en el colegio, etc.) es mucho más funcional e interesante para los escolares. 
El trabajo por proyectos implica una mayor coordinación entre el profesorado y la comunidad educativa. Un proyecto de relativa difusión en España es LOVA (La Ópera como Vehículo de Aprendizaje, http:// proyectolova.es/): se ha llevado a cabo en escuelas de enseñanza primaria y secundaria y consiste en realizar un musical teatralizado con los niños cuya preparación requiere todo un curso escolar y la colaboración de todas las asignaturas. El interés de estos proyectos exige dedicación, ilusión y formación por parte del profesorado, que lleva el peso de la organización y del trabajo colaborativo.

Sanmartín (2015) considera que, junto a la desconexión del mundo real que presenta la educación actual, es la falta de calidad del profesorado su mayor problema. Se hace eco de los datos de una encuesta dada a conocer en la Cumbre Mundial de Educación de Qatar (WISE) donde se les pregunta a profesores, estudiantes, políticos y empresarios de 149 países. La formación inicial de los profesores debe reforzarse, pues no existe en la práctica universitaria una buena combinación entre formación conceptual y didáctica (MARTíN, 2015). Pero también la formación continua debe ser imprescindible en la carrera docente. Los cursos de formación, las jornadas para el contraste de prácticas educativas y otros encuentros con distintos formatos que permitan el intercambio profesional, serán muy motivadores para los profesores que, dispuestos a trabajar con sus alumnos, tengan el gusto por el conocimiento y la ampliación de campos metodológicos con el fin de descubrir el mundo a sus estudiantes. Los profesores no pueden dejar de aprender para enseñar. La formación de equipos de investigación didáctica en los colegios es muy interesante para la calidad educativa $y$, sin duda, 
solo se pueden llevar a cabo con colaboración y una buena gestión por parte de los directivos y de la administración que facilite esta labor y la incentive.

Otro problema de la educación actual es la evaluación. Sugata Mitra, profesor de la Universidad de Newcastle y ganador del TED Prize 2013, dice que "los exámenes ya no sirven, son una amenaza" (TORRES, 2016). Considera que hay que acabar con los programas académicos para situar internet en el centro de aprendizaje. Una metodología de trabajo por proyectos plantearía cambios porque no se evalúan solo conocimientos, como en los tradicionales exámenes, sino procesos de trabajo e investigación, que incluyen razonamiento, creatividad, maneras de hacer...

De esta manera, podemos concluir que los trabajos por proyectos responden a un aprendizaje mucho más consciente, válido a largo plazo en la vida de los alumnos $\mathrm{y}$ totalmente funcional y actualizado. Los requerimientos son muchos pero, principalmente, es necesario una buena formación y disposición profesional por parte del profesorado, que debe saber llevar a sus alumnos en ese proceso de aprendizaje extrayendo y desarrollando sus mejores cualidades y capacidades para prepararlos en la vida social y profesional. El cambio educativo requerido es metodológico y, en este sentido, sí se puede hablar de una revolución educativa que implique una "revolución de la lectura" y el desarrollo de la creatividad.

\section{La revolución de la lectura}

El filósofo Emilio Lledó, Premio Princesa de Asturias 2015 de Comunicación y Humanidades, habla de la necesidad de una "revolución de la lectura". La lectura libera la 
mente, permite aprender a pensar con autonomía, formar personas críticas y creativas. Vivimos una época en que se lee y se escribe mucho, pero en un formato que ha dado lugar a una forma muy distinta de lectura y de comunicación escrita. Posado (2015) señala en qué se ha convertido la lectura en línea:

Nuestros terminales táctiles nos abren libros, revistas y periódicos. Pero me temo que nos quedamos en la portada, lo inmediato, la foto, el vídeo o el titular sensacionalista. Nuestra mente está sufriendo un estrés de inmediatez, todo acontece 'on line' y caduca al poco tiempo. No hay pausa y demora para la reflexión. Así es muy difícil entender cabalmente qué sucede (POSADO, 2015).

Esta lectura rápida y por encima responde a las necesidades de búsqueda que permite el formato web, con distintas tipografías que resaltan ideas y con hipervículos de apertura opcional. Y en este sentido cumple una alta funcionalidad en la que también hay que formar a los estudiantes para evitar pérdidas de tiempo. Pero el término "revolución de la lectura" de Lledó no se refiere a la lectura somera exigida en la selección de información; se refiere a la lectura profunda, a la que lleva al verdadero aprendizaje, al que supone transformación, interiorización de contenidos y emociones y procesamiento (figura 3). 
Figura 3 - ¿Qué es el aprendizaje?

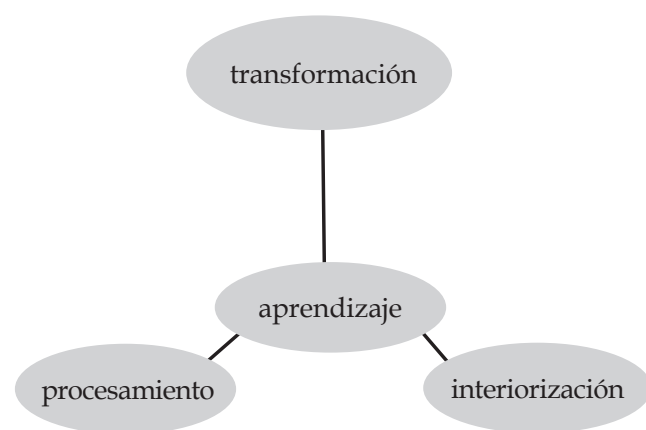

Fuente: Rosa Ana Martín Vegas.

Aprender a pensar es enseñar a aprender. $Y$ todo está inventado, la cuestión es ponerlo en práctica en las escuelas para acabar con el aprendizaje exclusivamente memorístico y conceptual que conduce a la desmotivación de tantos estudiantes por la falta de funcionalidad de los conocimientos aprendidos. El método para enseñar a aprender que ha de llevarse a cabo con la metodología de trabajo por proyectos (con todas las posibilidades posibles de trabajo que puedan imaginarse sobre cualquier tema) es la mayéutica socrática. Con este método, el maestro es un auténtico guía en el aprendizaje del alumno, pues a base de preguntas permite que los alumnos descubran los conocimientos gracias al acto de pensar. La labor del profesor es fundamental y para eso, como se ha comentado en el apartado anterior, ha de tener una excelente preparación y muy buenas aptitudes: debe saber conducir el proceso de aprendizaje mediante un buen planteamiento inicial de trabajo y buenos recursos que permitan la 
investigación del asunto. La técnica consiste en preguntar al alumno acerca del tema tratado y debatir las respuestas fundamentadas en conocimientos adquiridos en el desarrollo de la investigación. Poco a poco, los conocimientos se van ampliando y, gracias al saber, se encuentran soluciones a los problemas planteados. Este método permite desarrollar el pensamiento con todas sus implicaciones y prioriza el proceso de aprendizaje frente a los resultados. De esta manera, el alumno aprende realmente, porque es capaz de pensar por sí mismo gracias a su capacidad para realizar lecturas profundas, que relacionen lo que se lee con lo que se sabe del tema para extraer conclusiones propias que van más allá de la asimilación de unos contenidos transmitidos $\mathrm{y}$, a veces, no razonados.

\section{Conclusión: aprender a pensar para desarrollar la creatividad}

Hemos hablado de revolución de la educación y de revolución de la lectura, y todo esto, ¿para qué? El objetivo es desarrollar la creatividad, que permite desarrollar el talento de cada persona, que será necesario para la inserción social y profesional satisfactoria del estudiante en el futuro. En opinión de expertos en educación como Richard Gerver, la escuela actual mayoritaria condena la creatividad natural que tienen los niños. La escuela dirige tanto el aprendizaje ordenando a los niños qué deben aprender, cómo y en qué momento, que acaba con las dotes creativas que cualquier niño puede tener. La idea de Ken Robinson, orador y asesor en materia educativa de gobiernos e instituciones británicas y americanas, es que hay que poner a pensar a los niños para ayudarles a 
saber qué pueden hacer con lo que ya saben y con muchos más conocimientos que pueden adquirir. Esta es la idea expuesta en este artículo: hay que enseñar a pensar pensando y, para ello, es necesario un cambio metodológico que, con el uso de la tecnología digital, permita realizar la transformación necesaria para que el aprendizaje sea un procesamiento interiorizado por cada estudiante de forma que desarrolle todas sus capacidades intelectivas y creativas. Ayudarles a descubrir su talento es una tarea compleja pero posible.

\section{REFERENCIAS}

CASANOVA, O. Y. L. Bazarra. La escuela ya no es un lugar. Madrid: Arxic Formación, 2016.

CORBALÁN, R. Enseñanza digital en los Estados Unidos: ventajas y retos. En R. del Moral Aguilera, R. López Amate y A. Escobedo Rodríguez: Actas del XXXV Congreso Internacional de la Asociación Europea de Profesores de Español. Centro Virtual Cervantes: 73-77. Disponible en: <http:/ / cvc.cervantes.es/ensenanza/biblioteca_ele/ aepe/pdf/congreso_35/congreso_35_10.pdf>. 2001.

MARTÍN VEGAS, Rosa Ana Martin. La biblioteca escolar como centro de investigación. Mi biblioteca, n.38, p. 42-46. 2014.

MARTÍN VEGAS, Rosa Ana Martin. La Didáctica de la Lengua y la Literatura Españolas en el Máster en Formación del Profesorado de Educación Secundaria. Revisión y renovación. Revista española de pedagogía, n.261, p.365-379, mayo-ago. 2015. 
MILLER, F. Retos de la educación digital en 2016. Educación digital. Disponible en: < http://educacion. digital/retos-la-educacion-digital-2016/>

PARDO, I. La experiencia de la enseñanza en línea. Disponible en:<https://ismaelpardo.com/2016/09/19/ ensenaronline/>. 2016.

PENALVA, J. Así les va a los colegios e institutos que están acabando con el libro de texto. Xataka. Disponible en: <http://m.xataka.com/otros/asi-les-va-a-los-colegios-e-institutos-que-estan-acabando-con-el-libro-de-texto>. 2016.

PÉREZ-BARCO, M. J. Los veinte retos de la educación el siglo XXI. ABC.es. Disponible en: <http://www.abc. es/familia-educacion/20131211/abci-claves-educacion-201312101604.html>. 2013.

POSADO, J. La revolución de la lectura. La opinión. El correo de Zamora. Disponible em: <http://www.laopiniondezamora.es/opinion/2015/01/17/revolucion-lectura/816009.html>. 2015.

SANMARTÍN, O. R. (2015). Los cinco grandes problemas del profesorado español. El Mundo. Disponible en: <http:/ / www.elmundo.es/sociedad/2015/11/03/ 5637c9dc268e3e02488b456c.html>.

TORRES, Menárguez, A. (2016). Sugata Mitra: Los exámenes ya no sirven, son una amenaza. El País. Disponible en: <http:/ / economia.elpais.com/economia/2016/09/18/ actualidad/1474226496_636542.html>. 


\section{SOBRE OS AUTORES}

\section{ALEXSANDRO DA SILVA}

Graduado em Pedagogia (2000), mestre (2003) e doutor (2008) em Educação pela Universidade Federal de Pernambuco - (UFPE), com período sanduíche no Institut National de Recherche Pédagogique - (INRP) - Paris (2007). Desenvolveu estudos de pós-doutorado na Université Sorbonne-Nouvelle - Paris 3, em Paris (2015-2016). Atualmente, é professor adjunto do Centro Acadêmico do Agreste da Universidade Federal de Pernambuco, onde atua no curso de graduação em Pedagogia e no Programa de Pós-Graduação em Educação Contemporânea. É também docente do Programa de Pós-Graduação em Educação do Centro de Educação. Participa, ainda, do grupo de pesquisa Didática da Língua Portuguesa da UFPE. E-mail: alexs-silva@uol.com.br.

\section{ANA LUZIA DE SOUZA}

Graduada em Letras (Português-Espanhol) pela Universidade Federal Fluminense-RJ. Tem experiência na área de E/LE, já tendo lecionado em cursos de idiomas e 
na rede pública. É mestre em Lingüística y sus aplicaciones pela Universidad de Vigo - Espanha. Atualmente é professora do IFPB e aluna do Mestrado Profissional em Formação de Professores (UEPB). E-mail: annigna@hotmail.es .

\section{ANGELA PATRICIA FELIPE GAMA}

Doutoranda em Comunicação e Semiótica pela PUC-SP, com pesquisa relacionada aos estudos das poéticas urbanas, com ênfase na cartografia das artes visuais nos metrôs latino-americanos. Mestre em Comunicação e Semiótica pela PUC-SP (2009), com investigação a respeito das relações entre mídia, humor e estudos culturais na América Latina. MBA em Direção de Arte para Propaganda, TV e Vídeo pela UNESA (2015). Tem formação e atuação nas áreas de Linguagem \& Educação, Comunicação Social, Artes Visuais e Arte \& Mídia. E-mail: angelapfgama@ gmail.com.

\section{DANIELA GOMES DE ARAÚJO NÓBREGA}

Graduada em Letras Português/Inglês pela UFPB, com Mestrado em Letras (Inglês e Literatura Correspondente) pela UFSC e Doutorado em Letras/Linguística pela UFAL. Atualmente, é professora no Departamento de Letras e Artes e no Programa de Mestrado Profissional em Formação de Professores (PPGFP), da Universidade Estadual da Paraíba. É líder do grupo de pesquisa Formação Docente em LE do diretório da Capes/CNPq. E-mail: danielanobrega5@gmail.com. 


\section{FÁBIO MARQUES DE SOUZA}

Professor do Programa de Pós-graduação em Formação de Professores da UEPB e do Programa de Pós-graduação em Educação Contemporânea da UFPE. Coordenador adjunto do PPGFP/UEPB. Professor efetivo do curso de Letras-Espanhol, na UEPB, desde 2011. Cursou estágio de pós-doutorado (bolsista PNPD CAPES-MEC) no PPGEduC da UFPE. Mestre e Doutor em Educação, tendo como foco de investigação o ensino-aprendizagem de Espanhol-Língua Estrangeira/Adicional e a formação de professores para este idioma, obtidos, respectivamente, pela UNESP/Marília (2009) e pela Faculdade de Educação da USP (2014). Licenciado em Letras e Pedagogia. Líder dos grupos de pesquisa "TECLIN, Tecnologias, Culturas e Linguagens" e "Formação de Professores de Línguas Estrangeiras/ Adicionais" (UEPB), cadastrados no DGP do CNPq. E-mail: fabiohispanista@gmail.com.

\section{FERNANDO ZOLIN-VESZ}

Professor da área de Linguística no Departamento de Letras e no Programa de Pós-Graduação em Estudos de Linguagem (PPGEL) da Universidade Federal de Mato Grosso (UFMT). Doutor em Letras e Linguística pela Universidade Federal de Goiás (UFG), dedica-se a pesquisas sobre (des)colonialidade epistêmica nos estudos de linguagem. E-mail: fernando_vesz@hotmail.com.

\section{LAURA JANAINA DIAS AMATO}

Doutora em Letras pela UFPR. Professora do Programa de Pós-Graduação Interdisciplinar em Estudos LatinoAmericanos. Professora de Línguas e no curso de Letras 
- Artes e Mediação Cultural na UNILA. Tem experiência na área de Linguística, com ênfase em Linguística Aplicada, atuando principalmente nos seguintes temas: educação intercultural, processos identitários, formação de professores de línguas, letramento crítico, teoria pós-colonial. E-mail: laura.amato@unila.edu.br.

\section{LÍGIA BEATRIZ CARVALHO DE ALMEIDA}

Doutora em Educação, Mestre em Comunicação Midiática, Pedagoga e Bacharel em Comunicação Social. Professora do bacharelado em Comunicação Social da Universidade Federal de Campina Grande, PB. Integrante do grupo de pesquisa EpisCom. E-mail: ligiabia@gmail.com.

\section{MARÍA ISABEL POZZO}

Profesora, Licenciada y Doctora en Ciencias de la Educación, egresada de la Universidad Nacional de Rosario, Master en Formación de Profesores de Español como Lengua Extranjera (Universidad de Barcelona). Investigadora del Consejo Nacional de Investigaciones Científicas y Técnicas, profesora de la Escuela de Ciencias de la Educación y Directora fundadora del Centro de Estudios del Español como Lengua Extranjera, Universidad Nacional de Rosario, Argentina. Contacto: pozzo@irice-conicet.gov.ar.

\section{MARIA MORGANNA DA SILVA CASTRO}

Possui graduação em Letras e Especialização em Princípios Organizacionais da Língua Portuguesa, pela Universidade Estadual da Paraíba. É mestre pelo Programa de PósGraduação em Formação de Professores da Universidade 
Estadual da Paraíba. Atualmente, é professora de Língua Portuguesa da Secretaria de Educação do Estado da Paraíba e Professora do Instituto de Desenvolvimento Educacional Religioso e Cultural. E-mail: morgannascastro@hotmail.com .

\section{MARIANA PÍCARO CERIGATTO}

Doutoranda em Ciência da Informação pela Universidade Estadual Paulista (UNESP). Jornalista, mestre em TV Digital. Integrante do grupo de pesquisa EpisCom. E-mail: maricerigatto@yahoo.com.br .

\section{NATHALIA SATIRO}

Professora efetiva da Educação Básica do Estado da Paraíba desde 2013. Professora substituta do curso de Letras da UEPB desde 2014. Mestrado em Linguagem e Ensino, área de concentração em Ensino Aprendizagem de Língua e Literatura, pela UFCG (2016). Licenciada em Letras, com habilitação em Língua Inglesa, pela UFCG (2013) e bacharela em Comunicação Social, com habilitação em Jornalismo, pela UEPB (2010). E-mail: nathalialqs@gmail.com.

\section{ROSA ANA MARTÍN VEGAS}

Profesora Titular de Didáctica de la Lengua y la Literatura de la Universidad de Salamanca, España (USAL). Coordinadora de la especialidad en Lengua Española y Literatura del Máster Universitario en Profesor de Educación Secundaria Obligatoria y Bachillerato, Formación Profesional y Enseñanza de Idiomas de la USAL. Profesora y miembro de la comisión académica del Máster Universitario en Formación y Perfeccionamiento 
del Profesorado de la USAL. Licenciada en Filología Hispánica y Filología Italiana. Doctora en Filología con una tesis titulada "Morfofonología histórica del español". Autora de obras didácticas de amplia difusión como Manual de Didáctica de la Lengua y la Literatura (Síntesis, 2009) y Desarrollo del lenguaje en la Educación Infantil (Síntesis, 2015). Contacto: rosana@usal.es.

\section{SANDRA LEITE DOS SANTOS}

É mestranda no Programa de Pós-Graduação em Estudos de Linguagem (PPGEL) da Universidade Federal de Mato Grosso (UFMT). Sua pesquisa busca analisar a língua espanhola como dispositivo de exclusão social na obra Me llamo Rigoberta Menchú y así me nació la conciencia, de Elizabeth Burgos. E-mail: sanlei@hotmail.com.

\section{SIMONE DÁLIA DE GUSMÃO ARANHA}

Professora Doutora do Departamento de Letras e Artes da Universidade Estadual da Paraíba. Atualmente, coordena o Programa de Pós-Graduação em Formação de Professores (PPGFP/UEPB). Líder do Grupo de Pesquisa em Linguagem, Interação e Gêneros Textuais/Discursivos (LITERGE/CNPq). Desenvolve pesquisas fundamentadas em estudos da oralidade, da escrita e de gêneros textuais/discursivos na interface com linguagens (verbais, não verbais e multimodais) de ambientes virtuais e de rede. Interessa-se, ainda, pela análise dos níveis de interação entre o homem e a máquina e por estudos de fenômenos linguísticos - da Língua Portuguesa - com enfoque enunciativo e discursivo em gêneros diversos. E-mail: simone. dalia@yahoo.com.br . 


\section{SINARA DE OLIVEIRA BRANCO}

Professora Associada da Universidade Federal de Campina Grande, onde atua no Curso de Graduação de Licenciatura em Letras-Inglês e no Programa de Pós-Graduação em Linguagem e Ensino (POSLE) da Unidade Acadêmica de Letras. Possui Doutorado pelo Programa de PósGraduação em Inglês, com pesquisa na área de Tradução, da Universidade Federal de Santa Catarina (2007), Mestrado em Linguística (2002), também pelo Programa de Pós-Graduação em Inglês da UFSC, com pesquisa na área de Tradução, e Licenciatura em Letras-Inglês pela Universidade Federal da Paraíba Campus II (1993), atual Universidade Federal de Campina Grande. É Coordenadora da Pós-Graduação em Linguagem e Ensino (POSLE) da UFCG desde 2012. É líder do Grupo de Pesquisa Estudos da Tradução: Teoria, Prática e Formação do Tradutor, do DGP do CNPq. E-mail: sinarabranco@gmail.com .

\section{TAÍZA FERREIRA DE SOUZA CAVALCANTI}

Licenciada em Letras pelo Centro de Ensino Superior de Arcoverde. Especialista em Programação de Ensino de Língua Portuguesa pela Faculdade de Formação de Professores de Petrolina/UPE. Mestra em Educação Contemporânea pela Universidade Federal de Pernambuco. É professora efetiva de Língua Portuguesa nos anos finais do Ensino Fundamental na Rede Municipal de Educação de Buíque-PE. É também professora temporária no Centro de Ensino Superior de Arcoverde (CESA). E-mail: taizinhafsc@hotmail.com . 